


\section{Save the Children}

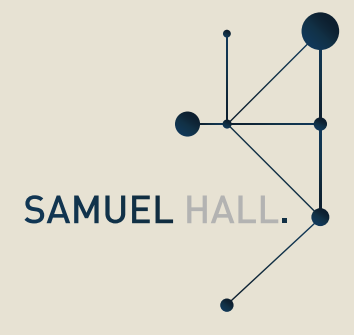

(C) Save The Children Sweden, 2018

Project Coordinator: Mikaela Hagan

Project Group: Karen Mets, Meike Riebau, Camilla

Scharffscher Engeset, Sarina Hiribae, Samirullah Popal,

Ronald Apunyo

Authors: Marion Guillaume, Nassim Majidi,

Samuel Hall samuelhall.org

Save the Children works in over 120 countries.

We save children's lives. We fight for their rights.

We help them fulfil their potential.

Samuel Hall is a social enterprise that conducts research in countries affected by issues of migration and displacement. Our mandate is to produce research that delivers a contribution to knowledge with an impact on policies, programmes and people. Our established network of researchers and field teams have a proven ability to adapt research methods to challenging contexts, bridging the gap between empirical and academic work. We provide our clients with: tailored, innovative research; expert analysis; practicable council; and access to the world's most fragile yet resourceful regions.

Design \& layout: BakOS DESIGN

Cover photo: $\odot$ Roya Heydari/Save the Children 


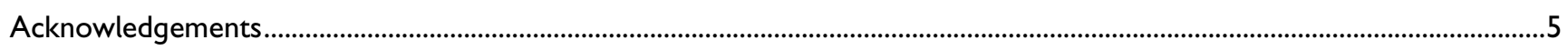

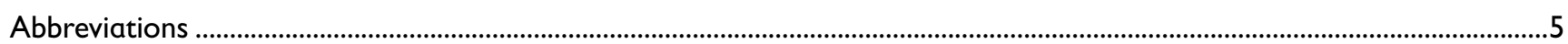

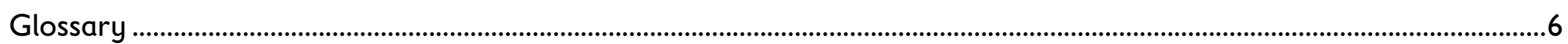

FOREWORD: Ensuring safe returns and durable solutions for children …….........................................................................

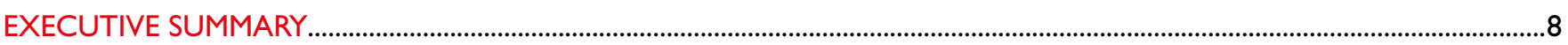

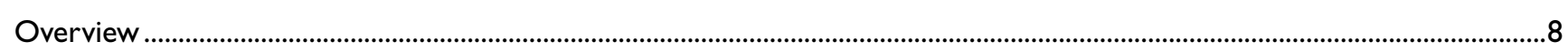

Context

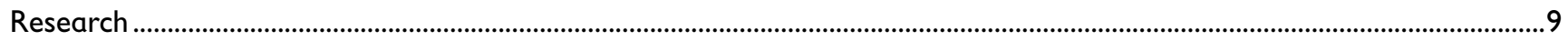

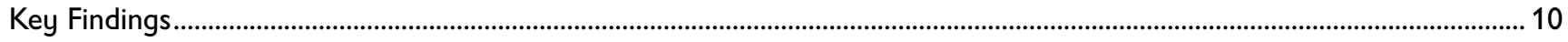

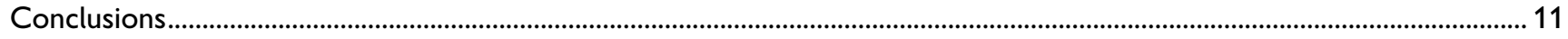

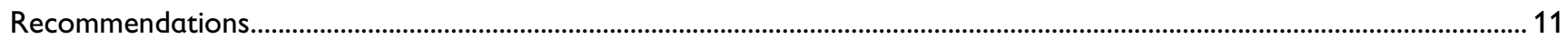

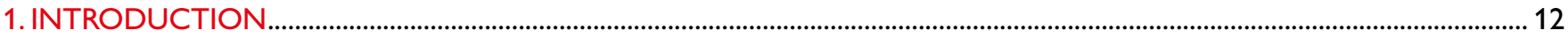

1.1 Children returning to Afghanistan ............................................................................................................................................... 12

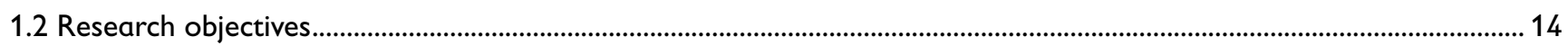

1.3 Research methodology .......................................................................................................................................................... 15

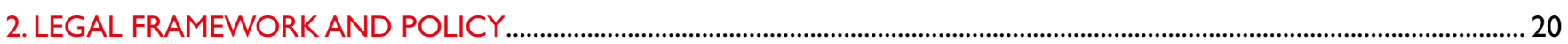

2.1 Key frameworks for understanding the return of children to Afghanistan ............................................................................ 20

2.2 Integration of international frameworks into EU and Afghan law..................................................................................... 24

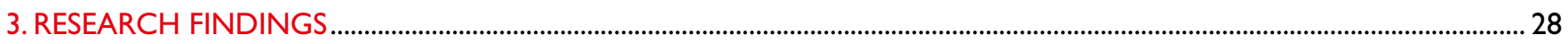

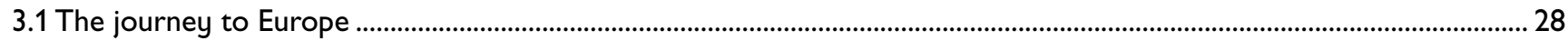

3.2 Return procedures and safeguards............................................................................................................................... 29

3.3 Conditions for return and reintegration in Afghanistan .................................................................................................... 36

3.4 Support needs and existing support systems ....................................................................................................................... 46

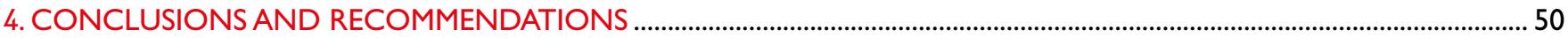

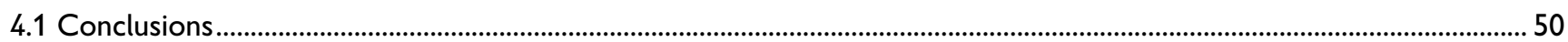

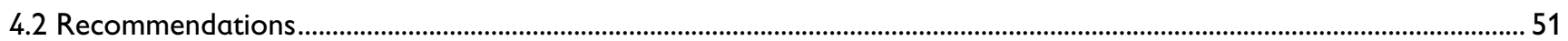

4.3 Overarching recommendations ..................................................................................................................................... 52

4.4 Recommendations to EU Member States and Norway.................................................................................................. 53

4.5 Recommendations to the EU and its institutions ............................................................................................................. 54

4.6 Recommendations to the Government of the Islamic Republic of Afghanistan (GolRA) …………………………........54

4.7 Recommendations to all stakeholders providing services to child returnees in Afghanistan..............................................56

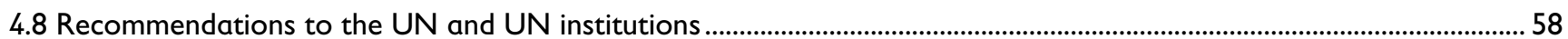




\section{FIGURES}

Figure 1: Final sample

- primary research conducted.

Figure 2: Key Articles in the UNCRC

related to conditions for return.

Figure 3: Were you interviewed

as part of the decision to return? 30

Figure 4: Did you return voluntarily? 31

Figure 5: Did you feel safe in the returns process?....... 33

Figure 6: Was violence or coercion

involved in the return process?.

Figure 7: Who returned to Afghanistan with you?........ 34

Figure 8: How would you rate the standard

of the housing you live in today?

Figure 9: Do you feel secure for yourself and your family outside when engaging

in daily activities? Returned children

Figure 10: Do you feel secure for yourself and your family outside when engaging in daily activities Parents/guardians

Figure 11: Do you suffer from

the following on a regular basis?

Figure 12: Do you feel like you belong to the community where you currently live?

Figure 13: Documents possessed by returned children

Figure 14: Pre-return priority support needs

Figure 15: Organisations currently and potentially working with children returned from Europe. 47
Table 1: Quantitative interviews disaggregated by country and type of return 17

Table 2: Afghan laws and policies relevant to children 26

Table 3: Pre-return support reported .33

Table 4: Key needs on return to Afghanistan, parents and children interviewed

34

\section{TABLES}




\section{ACKNOWLEDGEMENTS}

This report was written for Save the Children by Samuel Hall, an independent think tank providing research and analysis in countries affected by issues of migration and displacement. Thanks are due to the lead authors, Marion Guillaume and Nassim Majidi, and to Samuel Hall's field teams in Afghanistan, led by Mélissa Cornet and supported by Abdul Ghafoor of the Afghanistan Migrants Advice and Support Organisation.

We would also like to thank Save the Children project team - Mikaela Hagan, Karen Mets, Meike Riebau, Camilla Scharffscher Engeset, Sarina Hiribae, Ronald Apunyo and Samir Popal - for their thoughtful leadership, feedback and support. Special thanks also go to Save the Children's Rikke Johannessen, Josiah Kaplan, Ratirose Supaporn and Onno Van Manen and to our external reference group, including IOM colleagues in the EEA region and Afghanistan, Danielle Zevulun and PICUM's Lilana Keith.

In addition to the fieldwork in Afghanistan, Save the Children carried out interviews, consultations and focus groups with children, young people and families in Sweden and Norway. Special thanks to Rebecca Jafari, who led the consultations in Norway, and to colleagues in Save the Children Sweden, the Transforming Care Unit, and the Listen to Me project, who helped gather views and experiences in Sweden. Special thanks also to Veronica Granath, Sara Granath, Olof Molund, Osaman Basir, Sara Heinig and Adriana Aguilar of Save the Children Sweden and to The Association of Unaccompanied Youth (ESF) and their chairperson, Benjamin Fayzi.

Most importantly, thanks to the children, young people, parents and other adults who participated in this research and shared their stories, despite the challenges they face.

To protect the anonymity of the children and their families, all names in this report have been changed and specific interview locations withheld. Key informant interviewees are identified as representatives of the organisation they work for.

\section{ABBREVIATIONS}

\author{
ALCS Afghanistan Living Conditions Survey \\ CRC Committee on the Roghts of the Child \\ CSDSF Child-Sensitive Durable Solutions \\ Framework
}

CSO Civil society organisation

EU European Union

FGD Focus group discussion

GolRA Government of the Islamic Republic of Afghanistan

IDP Internally displaced person

IASC Inter-Agency Standing Committee

IFA Internal flight alternative

IOM International Organization for Migration

MoLSAMD Ministry of Labour, Social Affairs, Martyrs and Disabled

MoRR Ministry of Refugees and Repatriations

NGO Non-governmental organisation

PICUM Platform for International Cooperation on Undocumented Migrants

RSN Refugee Support Network

UK United Kingdom

UN United Nations

UNAMA United Nations Assistance Mission to Afghanistan

UNCRC United Nations Convention on the Rights of the Child

UNHCR United Nations High Commissioner for Refugees

UNICEF United Nations Children's Fund 
This research is based on an understanding of children's rights as defined in the United Nations Convention on the Rights of the Child (UNCRC), to which all European countries and Afghanistan are signatories. Durable solutions, especially return, have been conceptualised and considered under the umbrella of the Inter-Agency Standing Committee (IASC) Framework on Durable Solutions for Internally Displaced Persons, the interpretation of Article 3 of the UNCRC on the best interests of the child as elaborated by the UN Committee on the Rights of the Child, ${ }^{1}$ and safeguards in UNHCR's 2008 Guidelines on Determining the Best Interests of the Child.

Child: any human being below the age of 18 years (Article 1, UNCRC). The European Union follows this definition (Guidelines for the promotion and protection of the rights of the child, 2017). ${ }^{2}$

Unaccompanied children/minors: children outside of their country of origin as defined in Article 1 of the UNCRC who have been separated from both parents and other relatives and are not being cared for by an adult who, by law or custom, is responsible for doing so $^{3}$

Durable solution: A durable or sustainable solution is 'one that, to the greatest extent possible, protects the long-term best interests and welfare of the child and is sustainable and secure from that perspective'. ${ }^{4}$ This fits into broader displacement frameworks. For example the IASC Framework states that 'a durable solution is achieved when internally displaced persons no longer have any specific assistance and protection needs that are linked to their displacement and can enjoy their human rights without discrimination on account of their displacement' (IASC Framework on Durable Solutions for Internally Displaced Persons, 2010, UNHCR).

Best interests: Article 3.1 of the UNCRC states that 'In all actions concerning children, whether undertaken by public or private social welfare institutions, courts of law, administrative authorities or legislative bodies, the best interests of the child shall be a primary consideration.' To ensure that this happens, a best interests assessment (BIA) and best interests determination (BID) should be conducted to achieve durable solutions for children, including during returns processes (Safe \& Sound, UNHCR/UNICEF, 2014).

Return:The return of a rejected asylum seeker, refugee, displaced person or unaccompanied minor. Returns can be voluntary or forced. A voluntary decision encompasses three elements: (a) freedom of choice, which is defined by the absence of any physical or psychological coercion; (b) an informed decision which requires the availability of accurate and objective information upon which to base the decision; and c) the legal capacity on the part of the migrant to make an informed decision (or their legal guardian in the event they are not capable of doing so). ${ }^{5}$ Forced return is the compulsory return of an individual to the country of origin, transit or third country, on the basis of an administrative or judicial act (IOM Glossary on Migration, 2011).

Deportation:The act of a State in the exercise of its sovereignty in removing a non-national from its territory to his or her country of origin or third state after refusal of admission or termination of permission to remain (IOM Glossary on Migration, 2011).

Voluntary departure: Compliance with an obligation to leave the territory on the basis of a return decision/ removal order issued to a third country national irregularly staying on EU territory (EU Returns Directive).

Removal:The enforcement of an obligation to return in accordance with a return decision/removal order issued to a thrid country national irregularly staying on the EU territory (EU Returns Directive)

Reintegration: Reintegration can be considered sustainable when returnees have reached levels of economic self-sufficiency, social stability within their communities, and pyschosocial wellbeing that allow them to cope with (re)migration drivers. Having achieved reintegration, returnees are able to make further migration decisions a matter of choice, rather than necessity (IOM, 2017).

\footnotetext{
See CRC General Comment No. 14 (2013) on the right of the child to have his or her best interests taken as a primary consideration (art. 3, para among others EU Guidelines on the protection and promotion of the rights of the child, European Union, 2017

See for instance, CRC General Comment No. 6 (2006):Treatment of unaccompanied and separated children outside their country of origin

Guidance to respect children's rights in return policies and practices, UNICEF/UN Human Rights Office/IOM/Save the Children/PICUM/ECRE and Child Circle, forthcoming 
Afghanistan has a lot to offer in terms of hospitality, beautiful landscapes and intricate artwork. Sadly, every day life for its citizens continues to be affected by insecurity and conflict.Various armed opposition groups control and actively fight over large swathes of territory, while new actors emerge with complete disregard for the protection of civilians. Some extreme factions are also targeting education and health facilities.

This reality propels people to flee their homes - for political and ideological reasons, in search of economic opportunities, or simply to find a peaceful life away from war. Most Afghans - more than 6 million over the last three decades - go to the neighbouring countries of Pakistan and Iran. Others choose the longer and more dangerous journey to Europe. In 2016, Afghanistan, along with Syria and Iraq, was one of the top three countries of origin for asylum-seekers arriving in Europe. In 2017, nearly 44,000 Afghans filed for asylum in Europe. ${ }^{6}$

The perils of the journey to Europe cannot be underestimated. Families and unaccompanied children make immense sacrifices to undertake the risky and often traumatising journey to Europe. If they fail, many choose to try again, which demonstrates their level of desperation. Children are subjected to cruel treatment from traffickers and smugglers, and are often denied basic shelter, food, water and medicine. Even if they arrive in Europe, many are not granted refugee status. Between January and March 2018, only 44 per cent of decisions taken on Afghan asylum seekers resulted in their being granted refugee status. ${ }^{7}$
Those who are rejected sometimes return home. Many children who are sent back find themselves in unfamiliar territory, having never lived in or grown up in Afghanistan. Despite some progress on development indicators in Afghanistan, children and young people still face a host of challenges to learn, survive and be protected. In this report, children who have returned from Europe tell us about those challenges, as well as about their hopes and dreams for the future.

Save the Children is working in Afghanistan and Europe to find durable solutions to ensure the safe and dignified return of children, with the necessary guarantees in place to protect them. Until safe and sustainable returns can be guaranteed, we urge European governments to suspend the return of children to Afghanistan.

We hope that this report can contribute to the dialogue around returns and increase knowledge and cooperation between all actors in Afghanistan and Europe to further the wellbeing of migrants, refugee and returnee children, young people and their families.

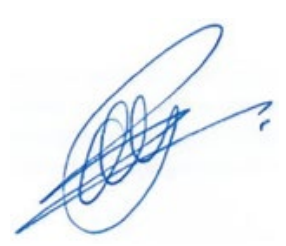

Onno van Manen

Country Director, Save the Children in Afghanistan 


\section{OVERVIEW}

This report assesses the impact on children of being returned from Europe to Afghanistan. Through interviews with individual children, their parents or guardians, and with governmental and non-governmental actors, it builds a picture of children's material, physical, legal and psychosocial safety during the returns process. Returns processes implemented by EU member states and Norway are examined to analyse where European governments are failing to provide appropriate support.

The exact number of children returned from Europe to Afghanistan is unknown. ${ }^{8}$ Our research team spoke with $57^{9}$ of these children during spring 2018. In addition, Save the Children carried out interviews, consultations and focus group discussions with Afghan children, young people and families in Sweden and Norway.

The results are disturbing: nearly three-quarters of the children interviewed did not feel safe during the returns process. Over half reported instances of violence and coercion and nearly half arrived in Afghanistan alone or were escorted by police. On arrival, the children received little or no support, and only three had a specific reintegration plan. While 45 children had attended school in Europe, only 16 were attending school in Afghanistan. Ten children said attempts had been made to recruit them to commit violent acts, while many others spoke of discrimination, insecurity and sadness. Of the 53 children who completed questionnaires, only ten neither wish nor expect to re-migrate in the next year. Clearly, the processes and support necessary to ensure sustainable returns for children are not in place.

Evidence collected through this research also forms the basis of specific recommendations to European governments that are currently returning children and young people to an unsafe environment and unsustainable futures. It urges the EU and Norwegian governments to halt the return of children to Afghanistan until the security situation has improved and all the necessary safeguards are in place to ensure that children's rights, as enshrined in the UN Convention on the Rights of the Child (UNCRC) are respected.

\section{CONTEXT}

The UNHCR reports that, in Afghanistan, 'civilians bear the brunt of this conflict'..$^{10}$ The overall security situation in Afghanistan has deteriorated significantly in recent years in all areas of the country, particularly in Kabul. ${ }^{11} \mathrm{New}$ data show that the first half of 2018 was the deadliest ever for Afghan civilians, with 1,700 people killed.Afghanistan is one of the main countries of origin for children and families seeking asylum in Europe.

In 2015 and 2016, 600,000 Afghans applied for asylum in the European Union (EU). ${ }^{12} \ln 2017$, this dropped to 43,625 first-time asylum applications.

On 2 October 2016, the EU and the Afghan government agreed a Joint Way Forward. This agreement was intended to facilitate returns to Afghanistan and in 2017, 4,260 people returned from the EU. ${ }^{13}$ Given the overall political pressure for quicker and more effective returns, this number is expected to increase..$^{14}$ Existing research on returned children is limited, anecdotal, and specific to one European country or one type of return. ${ }^{15}$ Identifying child returnees from Europe in Afghanistan is challenging. They form a hidden population in the country.

\footnotetext{
As per the UNCRC, EU returns directive, and other child-specific international and national laws

Of the 57 individual child returnees interviewed, four did not fill in a questionnaire. There are therefore references to 57 and 53 children throughout the report.

5 Existing research does not focus on children - and child-specific rights - in the context of returns. The most recent relevant works are Amnesty International's 2017 Forced Back to Danger, which interviewed 26 Afghans returned to Afghanistan (including both adults and children), the Refugee Support Network's 2016 After Return: Documenting the Experiences of Young People Forcibly Returned to Afghanistan, which focuses on Afghans just turned 18 deported from the UK (with final data based on 25 young persons returned), and Oxfam's 2018 Returning to Fragility: Exploring the Link between Conflict and Returnees in Afghanistan which considered returns in Afghanistan's current context more broadly.
} 


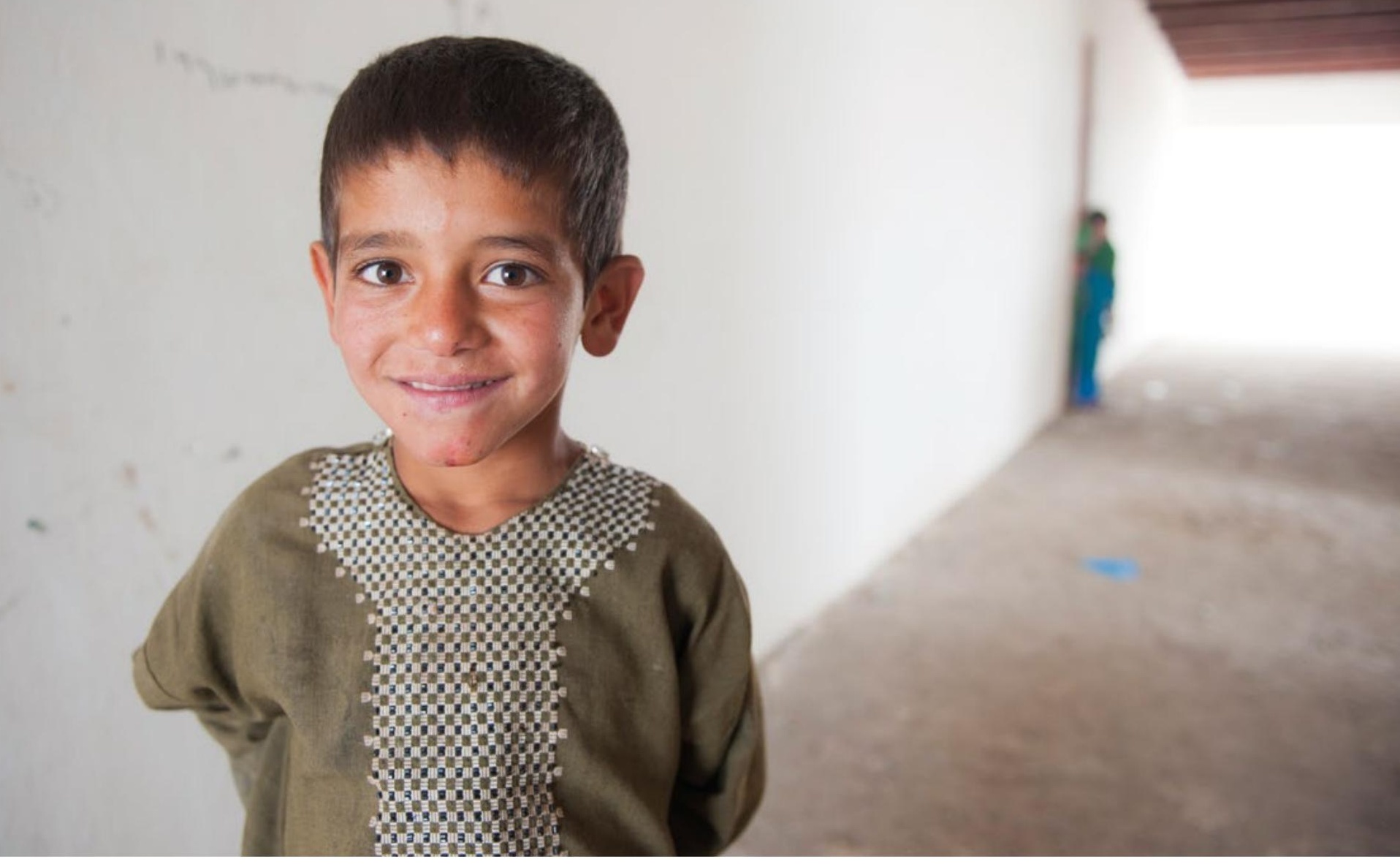

(C) Zubair Sahir Sherzay/Save the Children. The child in the photo did not participate in the research.

The Afghan government elaborated a National Strategy on Returns and Reintegration, but the massive scale of refugee returns from Iran, Pakistan and Europe poses significant challenges. ${ }^{16}$ The Child Act, which addresses the rights of children in Afghanistan, still awaits approval.

As European governments seek a reshaped common migration policy, this report highlights gaps and inconsistencies in policies and processes that prevent children's rights being respected in return settings. This case study of returns to Afghanistan reminds states of their obligations to put the rights of children ahead of migration management agendas.

\section{RESEARCH}

The research conducted for this report assesses the implications of returns for child returnees from Europe to Afghanistan. Interviews were conducted at three levels: the individual child; the community (parents, guardians and local stakeholders) and structural (governmental and non-governmental actors). In total, 57 individual child returnees, 24 parents or guardians and 30 key informants were interviewed in Afghanistan, ${ }^{17}$ with additional interviews carried out with Afghan children, families and professionals supporting them in Norway and Sweden. ${ }^{18}$ The research gathered information on children's material, physical, legal and psychosocial safety (including mental health), with a focus on information around specific rights accorded to children, in particular by the UNCRC. ${ }^{19}$

\footnotetext{
16 Of the over 2.3 million returns recorded between 2015 and 2017, just under 15,000 were estimated to be from Europe. See for example Returning to Fragility: Exploring the Link between Conflict and Returnees in Afghanistan, Oxfam, January 31, 2018 and Forced Back To Danger, Amnesty International, October 2017. Specific numbers for children are not available overall.

17 Stakeholders include representatives of the government and several European governments, Save the Children and other NGO staff members, international organisations working with children (such as UNICEF) and Afghan CSOs.

18 Consultations were conducted with: 16 unaccompanied children and young people in Sweden and Norway; 30 parents in Sweden and Norway; 8 children in families in Norway.A further 150 calls to the Save the Children helpline were considered, and 140 questionnaires completed by professionals, primarily education-related, in Sweden. Finally, consultations were conducted with representatives from CSOs and authorities in Sweden, and with guardians in Norway.

19 Chapter 2 further details these rights and durable solutions frameworks, as well as relevant European and country-level laws.
} 


\section{KEY FINDINGS}

\section{Safety in the Returns Process}

- Nearly three-quarters (39 out of the 53 children who completed questionnaires) did not feel safe during the returns process, with over half of them reporting instances of violence and coercion.

- Almost one in five children (10 of the 53 children) reported returning alone and 16 said they were accompanied by police.

- Despite guidance against forced removals, several children reported heavy police involvement in returns.

- Follow-up with families of unaccompanied children returned to Afghanistan is almost non-existent.

\section{Lack of Support During the Returns Process}

- Only three children interviewed received a specific reintegration plan.

- Although most families and children returning from Europe are entitled to money and travel expenses when they return, child-specific support remains limited to non-existent.

- Only one child who returned alone stated that the authorities abroad contacted family members prior to return.

\section{Physical Safety}

- Children face a very real threat to their physical wellbeing on return. In Afghanistan, neither children nor parents reported feeling secure outside when engaging in daily activities.

- Ten out of the 53 children who completed questionnaires stated that someone had "attempted to recruit them to fight in combat, commit acts of violence, or otherwise engage with armed groups".

- Almost across the board, children and parents interviewed in Sweden and Norway named security as a major risk they would face on return.

\section{Material Safety}

- The housing and economic situations are insufficient to meet the UNCRC's mandate of a standard of living 'good enough to meet their physical and mental needs' (Art. 27).

- Only 16 children of those interviewed were currently at school. While several are now older and less likely to be in school, this remains a steep drop-off and, in some cases, a stark contrast to life abroad, where 45 of the children were in school. This is in line with broader trends in Afghanistan, where 44 per cent of primary-aged children and 42 per cent of lower secondary-aged children are out of school. ${ }^{20}$

\section{Psychosocial Safety}

- The child returnees do not always return to their families' province of origin, which means they are not returning to a social network or stable living conditions. Several of the children (eight) had never been to Afghanistan but were born in Iran or Pakistan. ${ }^{21}$

- The vast majority lack access to psychological healthcare, a widespread problem in Afghanistan, and have limited networks beyond their families. ${ }^{22}$ Children do not feel included in the communities to which they return.

- They exhibit negative symptoms of psychological wellbeing - from anger to sadness.

\section{Legal Safety}

- Most children have some form of documentation only five reported having none. For those missing it, this is a significant challenge to accessing both education and employment.

\footnotetext{
Global Initiative on Out-of-school Children, Afghanistan Country Survey, 2018, MoE (GoIRA), Samuel Hall/UNICEF

For more information on Iran-born Afghans, see Second-generation Afghans in Iran: Integration, Identity and Return,AREU,April 2008

22 Children returned under IFA or alone just after their $18^{\text {th }}$ birthday in particular may not have familial networks present; older young people whose families sponsored their migration may return to families upset by their lack of 'success' in migration. A recent article detailing the story of Hussain, 27, deported from Finland, detailed his welcome as follows: "When he arrived home, his family didn't know of his deportation and was initially happy to see him. But the mood quickly changed. They now remind him daily of the financial sacrifices they made to get him to Europe." Majidi, N." Young Afghans Returning from Europe Face Isolation and Fear back Home"
} 


\section{CONCLUSIONS}

The research demonstrates that existing safeguards of children's rights are not being fully implemented. First, given the current Afghan security context, return cannot be considered a durable solution for a child. Even in zones deemed safe for internal flight alternatives by returning governments, the security context is worsening. ${ }^{23}$ Best interests procedures are inconsistently applied. Children are returning to an environment that does not enable them to fully access rights guaranteed in the UNCRC, including the right to protection, education and healthcare. Based on interviews with European government agencies, perceived legal responsibility by returning countries ends when children arrive in Afghanistan. Benefits provided to voluntary returnees (such as in-kind support) are often given at the family level, not necessarily benefiting children, and their type and scope depend on the returning country. ${ }^{24}$ Finally, there is limited communication between actors involved in returns, such as migration agencies, embassies, Afghan authorities and non-governmental organisations (NGOs) in Afghanistan.

\section{RECOMMENDATIONS}

- EU Member States and Norway should stop returning children to Afghanistan. Attempted recruitment, a lack of network, family and reintegration plans and the volatile security situation in the country mean that returning children to Afghanistan, whether unaccompanied or with their families, cannot be in their best interests.

- EU Member States and Norway should fully and consistently apply internationally accepted standards on best interests procedures. Formalised multidisciplinary best interests procedures should precede the identification of a durable solution for a child, duly taking into account the child's views.

- EU Member States and Norway should support migration and returns agencies in the development of robust child safeguarding and child protection policies. To ensure children feel safe during returns procedures, migration and returns agencies should develop child safeguarding and child protection standards to apply during returns procedures. These should include training of staff accompanying children in returns procedures, having a child protection and child safeguarding focal point during returns operations, and ensuring that families stay together during returns operations.

- EU Member States, Norway and the Government of Afghanistan should ensure that all children receive child-specific support in return procedures and individual reintegration plans. These plans should include mechanisms for post-return monitoring, coordinated between returning Member States and agencies, the country of origin and local child protection actors.

- The Government of Afghanistan should include returnee children in developing policies addressing child protection and child returnees, such as the Child Act. 


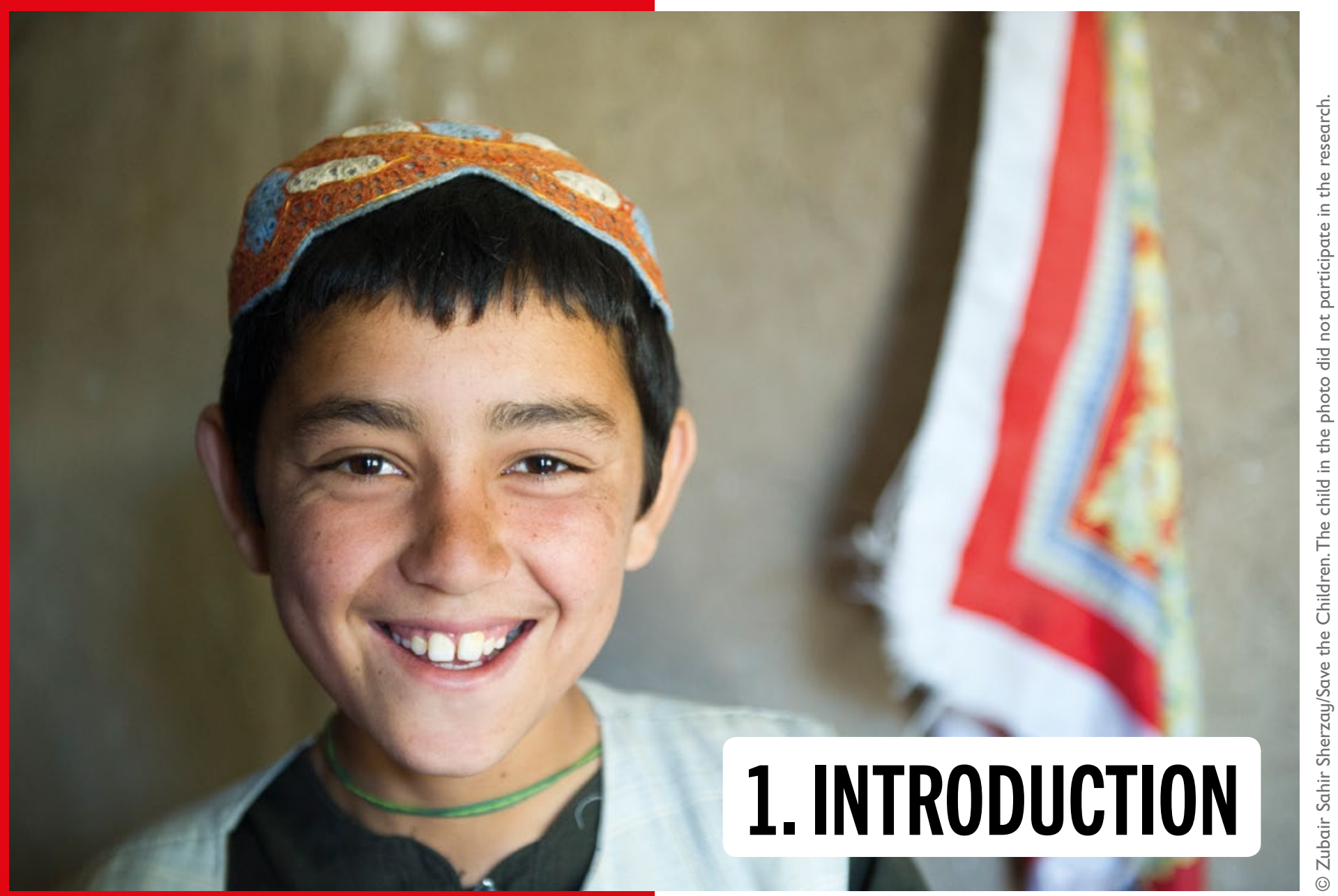

\subsection{CHILDREN RETURNING TO AFGHANISTAN}

Afghanistan is one of the main countries of origin for both unaccompanied and separated children and children in families seeking asylum in Europe. Official numbers peaked in 2015 and 2016, when almost 600,000 asylum applications were registered by Afghan asylum seekers in the European Union (EU). ${ }^{25}$ In 2017 this dropped to 43,625 first-time asylum applications. ${ }^{26}$ European governments are still addressing the 2015-16 applications. Decisions have been slow to come and often inconclusive for Afghans: in 2017, only 46 per cent of first-instance decisions on asylum applications by Afghans in the EU were positive. ${ }^{27}$ Although a negative answer does not entail an immediate return to Afghanistan, some will return to Afghanistan either by choice or by force.Among these are families and children, as well as young people who recently turned 18 . EUROSTAT data approximates that 8,340 people returned from the EU to Afghanistan in 2016; numbers decreased in 2017 , confirming an overall

25 Global Trends - Forced Displacement in 2015, UNHCR, and Eurostat data 2016, Eurostat

26 Asylum applicants in the EU, Eurostat, 2017

27 See EUROSTAT Data on asylum recognition rates, published in April 2018 
trend of falling returns rates in that year. Given the political pressure for quicker and more effective returns, an increase is expected. ${ }^{28}$

The number of children returned is unknown. No governmental agency interviewed for this research in Kabul - Afghan or other - was able to provide the total number of unaccompanied or separated children, nor that of those returned as part of a family. ${ }^{29}$ Our research team spoke to 57 of these children.

As European governments seek a reshaped common migration policy, this study highlights gaps and inconsistencies in policies and processes that prevent children's rights from being respected in return settings. It reminds states of their obligations to put the rights of children ahead of migration management agendas. Currently, there is a lack of clarity about what happens to children returning to Afghanistan. Existing research on returned children is limited and anecdotal, specific to one European country or one type of return. ${ }^{30}$ The Afghan government developed a National Strategy on Returns and Reintegration, but the massive scale of refugee returns from Iran, Pakistan and Europe poses significant challenges. ${ }^{31}$ The Child Act, which addresses the rights of children in Afghanistan, still awaits Parliament's approval.

This report provides information on children's experiences of return to Afghanistan, voluntary or not, to understand whether these returns are appropriate and in line with children's rights set out in the United Nations Convention on the Rights of the Child (UNCRC). ${ }^{32}$ Specifically, evidence is needed to understand the situation faced by child returnees with regards to their physical, material, psychosocial and legal safety. This report generates information to address existing gaps in knowledge around:
- Conditions for return in the country of origin. Access to healthcare, adequate standards of living and protection from violence, among others, are threatened and in some cases violated.

- Existing support and networks. Children 'return' to a country they may never have been to before or, under the European 'internal flight alternative', to areas of the country where they have no network. ${ }^{33}$ The implications of Afghan and European policies on return and reintegration is discussed, as well as whether the support currently provided to children before and after return is sufficient.

\section{- Procedural safeguards to ensure return is a} durable solution. At an individual level, procedural safeguards should exist to ensure children's rights are considered in return processess.

\section{Research context and relevance}

Afghanistan's overall security situation has deteriorated significantly in recent years, even during the course of this study, particularly in Kabul but also across the country. ${ }^{34}$ Kabul ranks as the first province in terms of civilian casualties, although Nangarhar is fast catching up. In Herat, the security situation has been worsening, particularly in districts where the Taliban presence is greatest, outside the provincial capital itself..$^{35}$ More than 1.3 million Afghans have been internally displaced by these high levels of conflict. This is also confirmed by the European Asylum Support Office (EASO)'s country of origin information. ${ }^{36}$ During the second half of 2018, attacks on education facilitities increased sharply, causing high levels of casualties and emphasising the risks children face. ${ }^{37}$

\footnotetext{
See EUROSTAT data on enforcement of immigration decisions, June 2017

As per the UNCRC, EU returns directive, and other child-specific international and national laws

30 Existing research does not focus on children - and child-specific rights - in the context of returns. The most recent relevant works are Amnesty International's 2017 Forced Back to Danger, which interviewed 26 Afghans returned to Afghanistan (including both adults and children), the Refugee Support Network's 2016 After Return: Documenting the Experiences of Young People Forcibly Returned to Afghanistan, which focuses on Afghans just turned 18 deported from the UK (with final data based on 25 young persons returned), and Oxfam's 2018 Returning to Fragility: Exploring the Link between Conflict and Returnees in Afghanistan which considered returns in Afghanistan's current context more broadly.

31 Of the over 2.3 million returns recorded between 2015 and 2017, just under 15,000 were estimated to be from Europe. See for example Returning to Fragility: Exploring the Link between Conflict and Returnees in Afghanistan, Oxfam, 31 January 2018 and Forced Back To Danger,Amnesty International, October 2017. Specific numbers for children are not available overall.

32 Guidance on how to implement these (such as from UNHCR and the Committee on the Rights of the Child) has also been taken into account.

3 Returning to Fragility: Exploring the Link between Conflict and Returnees in Afghanistan, Oxfam, January 31, 2018, page 3

34 See UNAMA reports Afghanistan - Protection of Civilians in Armed Conflict, Mid-Year Report 2017 and Mid-Year Updates on the Protection of Civilians in Armed Conflict: 1 January to 30 June 2018

35 See for example Eight Herat Districts Facing Security Threats, Tolo News, July 31, 2017

${ }^{36}$ EASO's country of origin information -security update, May 2018: https://bit.ly/2J1DTse'

37 See for instance Education under attack 2018, Global Coalition to Protect Education Under Attack.
} 
Concerns around rapid urbanisation and the lack of social protection hold true in Herat as well. ${ }^{38}$ With Pakistan and Iran revisiting their positions on Afghan migrants, increasing returns from those countries compound pressure on services to support returnees. ${ }^{39}$

European countries deal with returns in different ways. In some countries, authorities are responsible for forced and voluntary returns alike and in some countries, such as Germany, the International Organization for Migration (IOM) is responsible for voluntary returns. Countries and actors use different definitions and implement procedural safeguards to various degrees. This research covers all categories and makes no distinction between the two. It also aims to bring children's experiences broadly into the discussion.

As the situation in Afghanistan worsens, migrationrelated political discourse in Europe is becoming increasingly restrictive and solidarity is waning. European governments make use of the 'internal flight alternative', a legal provision that enables them to return people to regions qualified as safe in countries generally deemed unsafe. Discussions are ongoing about the provision of reception centres for unaccompanied returned children, reiterating plans that previously failed due to the continued lack of a protection and child-sensitive approach. ${ }^{40}$ Recent figures show that the EU is tightening borders, rejecting asylum claims and attempting to speed up deportations. ${ }^{41}$

\subsection{RESEARCH OBJECTIVES}

Awareness of the risks children face upon return and their needs in the context of return and reintegration will serve as a basis for Save the Children to plan its advocacy and provide guidance in the development of policies, programmes, tools and methods to assist children, young people and their families in Afghanistan and Europe. This study seeks to answer the following question:

\section{What are the consequences of return for children returned from Europe to Afghanistan?}

The research contributes knowledge about the experiences returned children, including protection gaps both in the return process and after return, and provides information to improve assistance and European decision making. Specifically, the report aims to:

(1) CONTRIBUTETO KNOWLEDGE ON RETURNS Examine return processes and conditions of return for children returned to Afghanistan from Europe, with a focus on key reintegration indicators ${ }^{42}$ considered through the lens of children's rights. Through this study, a tool for assessing return and reintegration contexts will be tested.

(2) VOICE CHILDREN and YOUNG PEOPLE'S

EXPERIENCES OF RETURN and the risks they face The views and recommendations of Afghan children, returned voluntarily or by force, are presented.

(3) SUPPORT ADVOCACY, PROGRAMMING AND POLICY EFFORTS related to children in migration Identify protection gaps and concrete recommendations for the fulfilment of children's rights for Save the Children and other stakeholders during return processes and after return.

\footnotetext{
38 See Political and Economic Dynamics of Herat, USIP, 2015, which details its haphazard urbanization. Attempts to support returnees through Land Allocation Settlements near the city have proven a failure. See Afghanistan's displaced people: 2014 and beyond, Forced Migration Review, May 2014, page 2014

39 When considering potential strain on (re)integration resources, to these numbers should be added the more than 300,000 Internally Displaced Persons (IDPs) displaced in 2017 alone.

40 Denmark, Norway Eye Kabul Center for Minors Denied Asylum, TOLOnews, June 21, 2018

41 Eurostat statistics of enforcement of immigration legislation and Eurostat quarterly report 2018 (25\% drop in first time asylum applicants, 37\% recognition rate in 2018)

42 As defined in the IASC Framework and adapted to child-specific needs by Save the Children in their Child Sensitive Durable Solutions Framework (see Methodology Section)
} 


\subsection{RESEARCH METHODOLOGY}

\section{Research design}

To answer the main research question, Samuel Hall conducted research at three levels - the individual (with children who had returned to Afghanistan); the community (with some of these children's parents or guardians and local stakeholders); and the structural (interviews with governmental, NGO, UN, international organisation and civil society actors, and academic representatives of the international community). In total, 57 individual child returnees, 24 parents/guardians of such children and $30 \mathrm{key}$ informants were interviewed. ${ }^{43}$ Of the 57 individual child returnees interviewed, 53 answered a questionnaire and 12 did case study interviews. Four children were part of the case studies but did not fill in the questionnaire. This is why the research at times refers to 53 children. ${ }^{44}$ Additional data was collected by Save the Children from Afghan children and families, and professionals supporting them, in Norway and Sweden. ${ }^{45}$

\section{The research approach is designed around $\mathbf{a}$} child rights approach to durable solutions. Based on existing durable solution frameworks, it gathered information on indicators of material, physical, legal, mental health and psychosocial safety, with a focus on information around specific rights accorded to children, in particular by the UNCRC. ${ }^{46}$ The European consultations, along with the data gathered in Afghanistan, allow the research to consider return processes from different angles - including what happens pre-departure and the conditions faced by children after return, including procedural and returns-related safeguards and their application.

\section{CASE STUDY \\ 14-year-old boy, who was 12 when he returned from Germany}

- 14-year-old boy, who was 12 when he returned

- Country of return: Germany

- Reason for migration: Insecurity

- Migration history:Travelled with his parents and one brother

- Return status: Returned voluntarily with his family

- Future plans: the family wants to re-migrate

I preferred living in the refugee camp than here - from all angles: security, education, opportunities and tranquility. We were very happy with how we were treated in camps.

Until my mom said that she could no longer live here. She said life in the camp was too difficult for her: "It has been five months that we all have been living with foreign families in one apartment. I want to return to Afghanistan." My father explained to her all the troubles we had been through to arrive, that we risked our lives, that our death was almost certain. He asked her "now that we have arrived, how can we go back?" But my mother insisted. No one asked me - or my younger brother - if we were satisfied with the idea of going back to Afghanistan. No one consulted us. If they had asked me, I would have told them that I did not want to go back, that I was not satisfied. I did not want to live in war anymore. I don't want to not be able to study peacefully. I do not want to constantly be scared of the risk of kidnapping if I leave my home -- or being killed.

Stakeholders include representatives of the government and several European governments, Save the Children and other NGO staff members, international organisations working with children (such as UNICEF) and Afghan CSOs.

44 Stakeholders include representatives of the government and several European governments, Save the Children and other NGO staff members, international organisations working with children (such as UNICEF) and Afghan CSOs.

45 Consultations were conducted with: 16 unaccompanied children and young people in Sweden and Norway; 30 parents in Sweden and Norway; 8 children in families in Norway. A further 150 calls to the Save the Children helpline were considered, and 140 questionnaires completed by professionals, primarily education-related, in Sweden. Finally, consultations were conducted with representatives from CSOs and authorities in Sweden, and with legal guardians in Norway.

46 Chapter 2 further details these rights and durable solutions frameworks, as well as relevant European and country-level laws.
After a few days my father decided to return us all. I was very saddened by this decision. I did not want to leave Germany. Sometimes there is conflict in the house and everyone blames my mother for returning. My only happiness is that in 2018 (1397) I have been re-registered in school and can resume my schooling. I have just started going back to school. We want to (re)migrate to Europe. This will happen as soon as possible after my dad sells his property. We are willing to go through all the difficulties of the journey. 
Children were specifically included in the research, not just as participants but as actors. Children's feedback was used to adapt the research tools after the pilot framework, and the tools were designed to provide clear opportunities for children to express their opinions. Finally, two restitution meetings were held in Kabul to allow the children to discuss and respond to the research findings, further contributing to the final analysis and report. ${ }^{47}$

Before the research was carried out, an extensive child protection protocol was developed and referral pathways for children at risk were identified by Save the Children in Afghanistan. Several children were referred to relevant organisations for support. The do-no-harm principle and child safeguarding guided all decisions on research design and methodology.

\section{Research framework}

\section{Research tools}

The following tools were used to gather information:

I. Desk Review: Samuel Hall surveyed the limited literature on the topic of children returning to Afghanistan from Europe and the broader base of literature on return migration.

II. Quantitative survey with returned children/ young people and their parents/guardians/ heads of household: when possible, this survey provided information on return processes and conditions on return using a standardised questionnaire with primarily closed questions. The parental portion of the survey focused on those indicators for which they could better give an answer (material and legal safety) while the child portion focused on their experiences, including physical and mental health and psychosocial safety.
III. Case studies with child returnees: children expressed opinions around their return experiences through narrative questions, interactive tools and role play.

IV. Key informant interviews: Samuel Hall interviewed actors knowledgeable on returns and/ or children's rights (including risks and needs in Afghanistan).

\section{Sampling}

Interviews with children and their parents. Children interviewed had travelled to Europe when they were older than eight and younger than 18 and returned to Afghanistan aged between 10 and 18. Three groups were considered:

- Children who returned unaccompanied before turning 18

- Children who returned with their families

- Children who returned alone within the year following their $18^{\text {th }}$ birthday. ${ }^{48}$ Although no longer defined as children in the UNCRC, these individuals go through child asylum-seeking procedures and should have access to durable solutions as children. Their return is tied to their age. ${ }^{49}$ Given the practice of returning young people as soon as they turn 18 years of age to avoid child rights obligations, understanding their situation is important. ${ }^{50}$

To ensure that younger children were represented in the sample, a maximum of 15 interviews with children returned after their $18^{\text {th }}$ birthday was set. A gender quota - targeting a minimum of three interviews with girls in Herat province and five in Kabul (eventually, three were interviewed in Herat and four in Kabul) - was also set to ensure that girls' specific experiences were integrated. Sixteen children interviewed had returned less than a year ago, 14 a year ago, another 14 two years ago, and the remaining nine three to four years ago.

47 Samuel Hall followed the ethical principles and considerations highlighted by UNICEF in its working paper What We Know about Ethical Research Involving Children in Humanitarian Settings:An overview of principles, the literature and case studies (June 2016) in designing this research, particular the seven categories identified as requiring reflection in the specific setting to the research, namely: Institutional capacity to involve children in research; Understanding power relations; Harms and benefits; Informed consent and capacities of participants; Privacy and confidentiality (including ICT); Payment, compensation, ancillary services and reciprocity; and Communication of results.

48 In this research, unless noted otherwise references to child returnees interviewed can be understood to include children returned alone within the year after their $18^{\text {th }}$ birthday.

49 In some cases, long asylum procedures mean they age out.

50 A 2016 article in The Guardian cites Labour MP Louise Haigh, describing this process: '“'Children who flee countries ravaged by war in the most appalling of circumstances are granted safe haven and build a life here in the UK, but at the age of 18 can be forced on to a flight and back to a dangerous country they have no links to and barely any memory of." See Refugee crisis:Thousands of child asylum seekers deported back to war zones, Home Office admits, The Guardian, February 9, 2016 
Table 1: Quantitative interviews disaggregated by country and type of return*

\begin{tabular}{l|r|r|r|r}
\hline Country/status & Unaccompanied minor & Family return & $18+$ & Total \\
\hline Austria & 1 & 2 & 3 & 6 \\
\hline Bulgaria & & 2 & & 2 \\
\hline Germany & 3 & 3 & 3 & 9 \\
\hline Greece & & 2 & 1 & 3 \\
\hline Netherlands & 3 & 2 & 1 & 3 \\
\hline Norway & 4 & 7 & 7 & 17 \\
\hline Sweden & & & 8 & 12 \\
\hline UK & 11 & & 1 & 1 \\
\hline Total & & 18 & 24 & 53
\end{tabular}

* The category of $18+$ here returned alone to Afghanistan; those in the 'family' category were aged under 18 , as were unaccompanied minors.

The research team sought to interview children who had been in a variety of European countries, with the specific inclusion of children returning from Germany, Norway and Sweden given the involvement of Save the Children organisations in those countries in the research. Children interviewed had returned from eight European countries: Austria (six); Bulgaria (two); Germany (nine); Greece (three); The Netherlands (three); Norway (17); Sweden (12); and the UK (one). The research included voluntary and involuntary returns based on children's own view of whether their return was voluntary or not and whether they felt involved in the process.

\section{Research was conducted in two cities in}

Afghanistan: Herat and Kabul. While there are no official figures for the number of children returned in terms of specific destination, these cities were selected as they are among the largest urban centres in the country and therefore highly likely to have a large returnee population. They are both deemed appropriate by returning governments for internal flight alternative (IFA) returns. However, given the current security, human rights and humanitarian situation in Kabul, an IFA is generally not available in the city according to UNHCR. ${ }^{51}$

In 24 cases, parents/guardians of children who had returned were also interviewed to gather further information. These were parents/guardians of all three types of children (unaccompanied/family/just turned 18).
Case study respondents included boys and girls interviewed for the quantitative survey and other child returnees. The research team only conducted case studies with children who had been interviewed for the quantitative survey when they expressed willingness to further share their stories.

Given the low sample size and difficulties in identifying respondents (see Research Limitations), the research team interviewed all children fitting the above criteria who could be identified during the research period. The research team adopted a referrals-based approach to the identification of child returnees for interviews, reaching out to community leaders, local civil society organisations (CSOs), non-governmental organisations (NGOs), international organisations, representatives from European governments and their service providers, and child returnees to find other returnees to interview.

All interviews were conducted face-to-face, except for three quantitative surveys conducted by phone with child returnees who moved from Kabul to Bamyan, Ghazni and Balkh, and one case study with a child returnee who remigrated to Turkey. Save the Children conducted further focus group discussions and consultations with children and families seeking asylum in Norway and Sweden. 
Figure 1: Final sample - primary research conducted

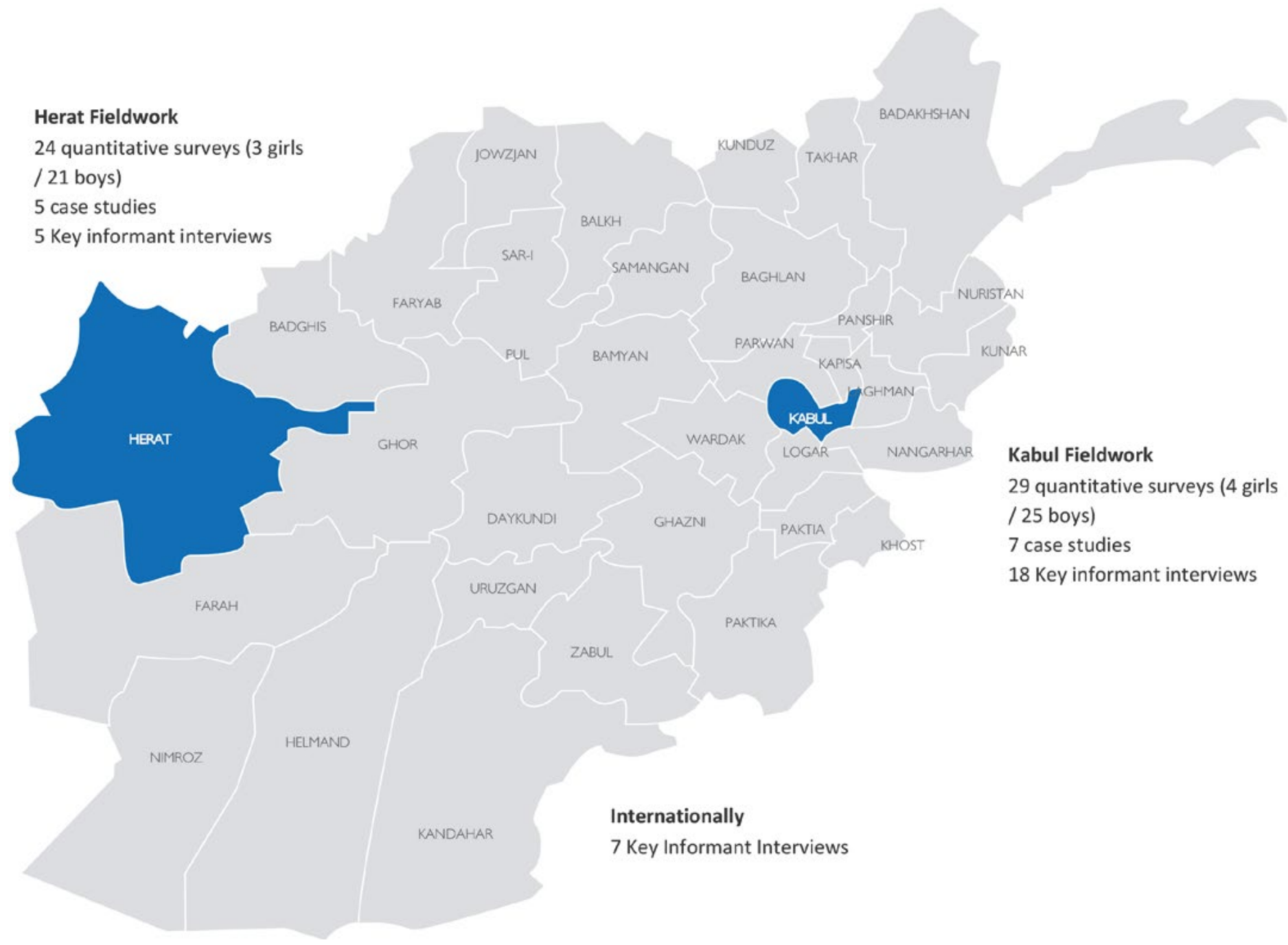

\section{Research limitations}

Interviewing children returned from Europe to

Afghanistan presents several difficulties. First, child returnees returned from Europe form a hidden population in Afghanistan; identifying them is inherently challenging. No agency or ministry keeps a clear record of all groups of child returnees from Europe and returning countries do not conduct structural follow-up.
The fear of stigma or risks associated with being known to have lived abroad means that child returnees from Europe may try to avoid being identified as such. High re-migration rates complicate the identification and interviewing of child returnees from Europe so the sample interviewed is neither statistically significant nor representative. However, stratified targeting was used to ensure the inclusion of different sub-groups of interest. 
Secondly, few girls who had returned from Europe were identified. This was anticipated since key informants confirmed that most unaccompanied child and young returnees are boys. ${ }^{52}$ This reflects trends in unaccompanied children seeking asylum. Of the girls interviewed, all had migrated with their families.

\section{Thirdly, the small sample size limited the} granularity of the research. Where clear differences and trends in the answers given were visible they are presented in the report, but generally such comparisons were not scientifically feasible. Key differentiators considered included gender, whether the children felt their return was voluntary or not, whether or not they were accompanied by family members, and the location of return.

Finally, security challenges led to the removal of Nangarhar as a fieldwork location. The research team focused its efforts on Kabul and Herat.

Given the difficulties in identifying respondents and the low sample size, the findings of this research should be considered illustrative. It is a qualitative study that does not claim to be statistically significant, but nonetheless represents one of the most substantive explorations of child returns to Afghanistan available to date, and an important departure point for further research. By applying a broad approach, it is indicative of areas where children's rights could be stenghtened and where support could be improved.

\section{CASE STUDY \\ 19-year-old boy, who was 16 when he returned from Austria}

- 19-year-old boy, who was 16 when he returned

- Country of return:Austria

- Reason for migration: Insecurity, murder of his father by the Taliban

- Migration history:Travelled alone

- Return status: Deported

- Future plans:Wants to re-migrate to Europe

When I returned to Kabul, the first night, there was a suicide attack at the Intercontinental Hotel. Several Afghans and foreigners were killed. At that very moment, so much fear and panic entered my body and increased. Since I had had no preparation, since I didn't know anyone in Kabul, I came back to Herat. My mother and three brothers live in Pakistan together. They did not want me to join them there because of the Taliban harassment there. I was scared for my own safety because of the daily attacks, terrorism and the distance from my family, were my daily worries.

I think children who returned from Europe are treated differently from those who returned from Pakistan and Iran. Some people say that the children who went to Europe have become infidels and are not Muslims anymore. Therefore, I do not tell anyone that I went to Europe unless I need to.

I am not integrated here. I do not have my family with me. I do not go to school. I do not have a job or income. I am not happy with my current situation.

\footnotetext{
52 A key informant interview conducted with an official from the Swedish Migration Agency noted that he knew of no cases of female unaccompanied children returned to Afghanistan.
} 


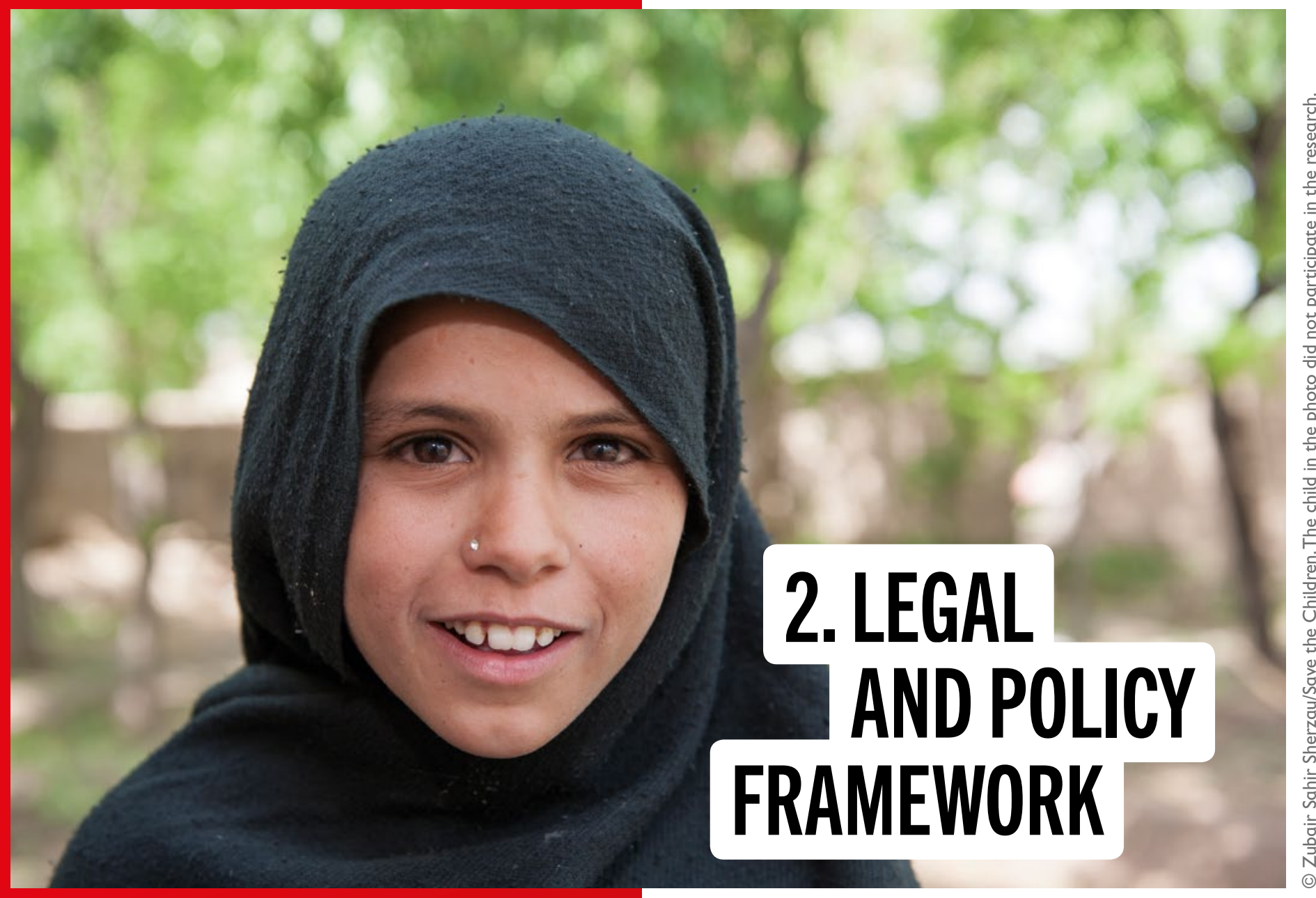

This chapter reviews key concepts and policy frameworks relevant to assessing the suitability of returning children to Afghanistan. Guidance is available in flagship documents: durable solutions guidelines, the UN Convention on the Rights of the Child (UNCRC), the Committee on the Rights of the Child (CRC)'s General Comments (which provide authoritative guidance on implementation of the UNCRC), the integration of the UNCRC into EU law, and the EU Return Directive. An overview of these frameworks concludes that states shall not return a child to a country where there are grounds for believing that there is a risk of irreparable harm to the child or when return is not in the best interests of the child.

\subsection{KEY FRAMEWORKS FOR UNDERSTANDING THE RETURN OF CHILDREN TO AFGHANISTAN}

\section{Understanding durable solutions}

Return is one of three durable solutions: return, resettlement and local integration. 'A durable solution is achieved when [...] persons no longer have any specific assistance and protection needs that are linked to their displacement and can enjoy their human rights without discrimination on account of their displacement.. ${ }^{53}$ The CRC and the Committee on the Protection of the Rights of All Migrant Workers and Members of Their Families further detail a durable solution as: 'A comprehensive, secure and sustainable solution is one that, to the greatest extent possible, caters to the long-term best interests and welfare of the child and is sustainable and secure from that perspective. The outcome should aim to ensure that the child is able to develop into adulthood, in an environment that will meet his or her needs and

53 "IASC Framework on Durable Solutions for Internally Displaced Persons", IASC, UNHCR,April 2010; page A-1 
Figure 2: Key Articles in the UNCRC related to conditions for return

PHYSICAL
Children are protected from
conflict (Articles 6, 38)
Children's life, survival and
development are protected
(article 6)
Children are protected from
abuse and trafficking
(Articles 19, 34-37)
Children do not suffer from
torture or other cruel,
inhuman or degrading
treatment or punishment, or
unlawful detention (Article 37 )

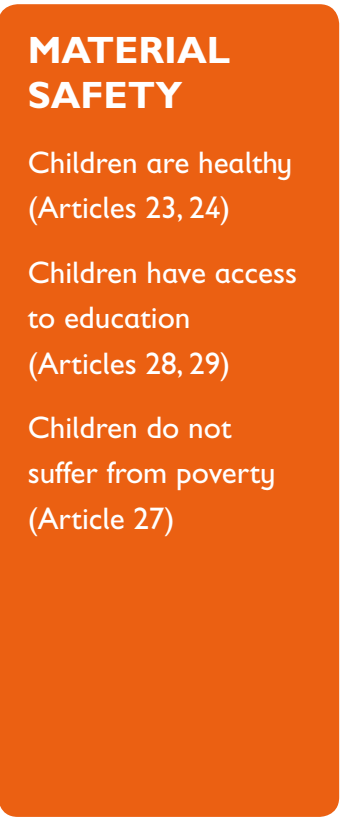

\section{MATERIAL}

Children are healthy

(Articles 23, 24)

Children have access

to education

(Articles 28, 29)

Children do not

suffer from poverty

(Article 27)

\section{PSYCHOSOCIAL SAFETY \\ LEGAL \\ SAFETY}

Children's mental

health is supported

(Articles 25, 39)

Children have a sense

of belonging

(Articles 13, 14, 30)

Children do not suffer

from discrimination

(Article 2)
Children have

civil documents

(Articles 4, 7, 8)

Children are united

with their families

(Articles 9, 10)

Children express

their views freely

in all matters

affecting them

(Article 12) fulfil his or her rights as defined by the Convention on the Rights of the Child. ${ }^{54}$ The identification of a durable solution should be based on a comprehensive approach to assessing and determining the best interests of the child.

Currently, durable solution frameworks ${ }^{55}$ are centred at the adult/household level and exclude child-

specific themes. Save the Children addresses this gap through its Child Sensitive Durable Solutions Framework incorporating elements from (1) general durable solutions principles and guidance and (2) child rights and protection standards. These are centred round four criteria - material safety, physical safety, legal safety and mental health and psychosocial safety. This framework has been the basis for assessing the conditions for return in Afghanistan. These frameworks are not applied in returns decisions but could be used in order to assess the general appropriateness of conditions for children in a specific context.

\section{The UN Convention on the Rights of the Child}

Globally, the foundation for children's rights is the UN Convention on the Rights of the Child (UNCRC), ${ }^{56} 57$ which all European governments and the Government of Afghanistan have signed and ratified. ${ }^{58}$ The legally binding Convention outlines state duties in protecting children, including child returnees. Afghanistan has not fully implemented the Convention in its national laws. No comprehensive law guaranteeing children's rights currently exists, but one is reportedly underway (the Child Act).

\section{Non-refoulement of children}

The non-refoulement principle is an essential protection under international human rights, refugee, humanitarian and customary law, and is therefore a core element of the legal framework on the return of children. It applies to all human beings, regardless of status.

\footnotetext{
54 Joint General Comment No. 3 (2017) of the Committee on the Protection of the Rights of All Migrant Workers and Members of Their Families and No. 22 (2017) of the Committee on the Rights of the Child on the general principles regarding the human rights of children in the context of international migration**

55 The IASC Framework, the UNHCR Handbook for Repatriation and Reintegration Activities, and IOM's Migration Governance Framework

56 Children are defined under the UNCRC as 'every human being below the age of 18 years unless under the law applicable to the child, majority is attained earlier', and are protected specifically by the UNCRC and its three additional protocols.

57 Convention on the Rights of the Child, OHCHR, United Nations, adopted on November 20,1989

58 United Nations Treaty Collection, https://bit.ly/2qMltm9

Note that "The Directive has been transposed into national law by all States bound by it (all EU States except UK and Ireland; plus the 4 Schengen associated countries: Switzerland, Norway, Iceland and Liechtenstein)." https://bit.ly/2thDUfe
} 
Under refugee law, it is enshrined in Article 33 of the 1951 Refugee Convention:

No Contracting State shall expel or return ("refouler") a refugee in any manner whatsoever to the frontiers of territories where his [or her] life or freedom would be threatened on account of his [or her] race, religion, nationality, membership of a particular social group or political opinion.

It is also enshrined in the Convention against Torture, ${ }^{59}$ the European Convention on Human Rights (through Article 3) and the EU Fundamental Rights Charter.

All European countries in this study are therefore bound not to send individuals to another country if they would then be at risk of serious human rights violations (such as execution, torture or other cruel, inhumane or degrading treatment, or other irreparable harm). Regarding children's refoulement specifically, in its Joint General Comment No. 22, the CRC and Committee for the Protection of the Rights of All Migrant Workers and Members of Their Families ${ }^{60}$ notes with concern that:

Some States parties choose to recognise a narrow definition of the non-refoulement principle.The Committees have already pointed out that the States shall not reject $a$ child at a border or return him or her to a country where there are substantial grounds for believing that he or she is at real risk of irreparable harm, such as, but by no means limited to, those contemplated under articles 6 (1) and 37 of the Convention on the Rights of the Child, either in the country to which removal is to be effected or in any country to which the child may subsequently be removed. Such non-refoulement obligations apply irrespective of whether serious violations of those rights guaranteed under the Convention originate from non-State actors or whether such violations are directly intended or are the indirect consequence of States parties' action or inaction.

This definition is broader than other definitions of nonrefoulement, as 'irreparable harm to the child' covers risks such as unlawful or arbitrary deprivation of liberty, inappropriate detention practices, underage recruitment, direct or indirect participation in hostilities, and risks to the child's survival and development. ${ }^{61}$ The Committee adds that 'the assessment of the risk [...] should, for example, take into account the particularly serious consequences for children of the insufficient provision of food or health services.' ${ }^{62}$

In all cases encountered in this report, the children were under the jurisdiction of the returning state and under their non-refoulement obligation. The question to keep in mind here is whether sending children back to Afghanistan exposes them to a risk of irreparable harm. NGOs such as Human Rights Watch ${ }^{63}$ and Amnesty International ${ }^{64}$ oppose returns to Afghanistan, generally based on non-refoulement obligations.

\section{Rights protected by the UN Convention on the Rights of the Child}

The UNCRC covers rights crucial in protecting children in the process of return and upon return to Afghanistan.

\section{Best interests of the child}

Article 3 entails a general obligation for States to consider the best interests of a child, a group of children or children as a group. This principle must be considered in all actions concerning children, including in the decision to return a child:

In all actions concerning children, whether undertaken by public or private social welfare institutions, courts of law, administrative authorities or legislative bodies, the best interests of the child shall be a primary consideration.

States Parties undertake to ensure the child such protection and care as is necessary for his or her wellbeing, considering the rights and duties of his or her parents, legal guardians, or other individuals legally responsible for him or her, and, to this end, shall take all appropriate legislative and administrative measures. ${ }^{65}$

\footnotetext{
Article 3 of the Convention against Torture and other Cruel, Inhuman or Degrading Treatment or Punishment. See also Article 16 of the International Convention for the Protection of All Persons from Enforced Disappearance. The Human Rights Committee in its interpretation of the 1966 Covenant on Civil and Political Rights encompass the obligation not to extradite, deport, expel or otherwise remove a person from their territory where there are substantial grounds to believe that there is a real risk of irreparable harm. For more information see e.g. OHCHR 'The principle of non-refoulement under international human rights law', 2018.

60 Joint General Comment No. 22, CRC, para 46.

61 "A Commentary on the Committee on the Rights of the Child's Definition of Non-Refoulement for Children: Broad Protection for Fundamental Rights", The Fordham Law School Institutional Repository, Res Gestae of HRW, December 2011, p. 42

62 Id.

"Pakistan Coercion, UN Complicity, the Mass Forced Afghan Returnees", HRW, February 2017

"Europe is betraying Afghanistan by Sending Its Refugees Home",A. Shea of Amnesty International in Times, October 5, 2017

Id.,Article 3
} 
This Article enshrines a core element of child protection. To ensure that a child's best interests are always safeguarded, States must perform a best interests determination (BID) as part of returns procedures. The precondition for the return of a child - whether unaccompanied, separated or within a family - is that their best interests have been examined, and return found to be in their best interests.

\section{Identifying durable solutions: best interests determinations and procedural safeguards}

In 2008, UNHCR developed Guidelines on Determining the Best Interests of the Child. ${ }^{66}$ These Guidelines describe $B I D$ as 'the formal process designed to determine the child's best interests for particularly important decisions affecting the child, that require stricter procedural safeguards. Such a process should ensure adequate child participation without discrimination. It should also allow the views of the child to be given due weight in accordance with age and maturity. It involves decisionmakers with relevant areas of expertise and balances all relevant factors to assess the best option. ${ }^{167}$ They detail clear procedural safeguards for determining the best interests of the child. ${ }^{68}$ The CRC's General Comment No. 14 goes into further detail on implementing the principle in guidelines relevant to all children. ${ }^{69}$

\section{The best interests of the child constitute a} primary consideration; considerations such as those relating to general migration control cannot override them..$^{70}$ If there is a conflict between the best interests of the child and the interests of the public or other persons such as family members, the rights of all parties involved must be carefully weighed. Procedural safeguards should be incorporated to ensure that the best interests of the child are examined before any decision on return and during return processes.

66 For more information see for example: Guidelines on Determining the Best Interests of the Child, UNHCR, 2008, Safe and Sound:What States can do to ensure respect for the best interests of unaccompanied and separated children in Europe, UNHCR/UNICEF, 2014, CRC General Comment no 14 (2013) on the right of the child to have his or her best taken as a primary consideration (art.3, para.1),

\section{Guidelines on Determining the Best Interests of the Child, page 23}

68 Id., page 57

69 General Comment 14, CRC, I.A.1, states "Article 3, paragraph 1, of the Convention on the Rights of the Child gives the child the right to have his or her best interests assessed and taken into account as a primary consideration in all actions or decisions that concern him or her, both in the public and private sphere."

\section{CASE STUDY}

\section{1-year-old boy, who was 18 when he returned from Sweden}

- 21-year-old boy, who was 18 when he returned

- Country of return: Sweden

- Reason for migration: Insecurity

- Migration history:Travelled alone

- Return status: Deported

- Future plans:Wants to re-migrate to Europe

I left Afghanistan because of the insecurity, after being close to a bomb explosion.

I saw so many difficulties on the road. When I crossed the Iranian border, I fell victim to thieves who took all the money that I had. In the forests, I saw so many cadavers.

When I got to Sweden, I was 17 years and 7 months, and therefore I was put with children until I turned 18. Meaning around five months later they put me with adults. For one year and seven months I was there, I was studying and working.

The moment I landed in Kabul, I was exhausted. I felt sad as I have no security here. I was tired but not hopeless. At least I could see my mother and father again. When I close my eyes at night I remember all the difficulties, everything I went through and coming back empty handed.

I have been with my family for the past month since my arrival and I am happy to be with them. I still live in fear of what happened to me and I do not go outside the house- unless it is in a car with a close relative. I am unemployed, and I just stay home. I attend family events but not social events outside. I want to travel to Europe through legal means and not illegal. 

durable solutions should look at all options, such as integration in a Member State, return to the country of origin, resettlement or reunification with family members in a third country. It is essential that a thorough Best Interests Determination be carried out in all cases.' As a general rule, EU law and policy that impacts children is required to be in line with the best interests of the child, and several legally binding frameworks include specific provisions on children's rights. The following are the most important in this context:

- Article 3(3) of the Treaty on the EU establishes the objective to promote the protection of children's rights.

- The Charter of Fundamental Rights of the EU guarantees the protection of the rights of the child by EU institutions and by countries implementing EU law.Article 24 on the rights of the child and Article 31 on the prohibition of child labour specifically cover children's rights.

- The European Convention on Human Rights (ECHR) provides standards applicable to migrants, including migrant children, regardless of status. ${ }^{75}$

- The Common European Asylum System contains various provisions on access to guardianship, age assessment, the child's best interests and access to rights such as healthcare and education.

Overall, the legal framework governing asylum and returns has become more restrictive in the last few years, with new measures being introduced that restrict access to international protection, such as temporary permits for children and an increased focus on medical age assessment procedures. These generate a lot of insecurity for children and have led to increased anxiety, depression and even self-harm and suicide across Europe. ${ }^{76}$

\section{EU return directive}

The return of third country nationals to their country of origin - including children - is governed by the

EU Return Directive. ${ }^{77}$. The Directive includes the following provisions:

- Article 5 calls for Member States to 'take due account of' the best interests of the child and family life when implementing the directive

- Article 10 guidelines for the return and removal of unaccompanied minors, listing necessary safeguards, including due consideration given to the best interests of the child, and ensuring that children can only be returned to a family member, a nominated guardian or 'adequate reception facilities'

- Article 14 access to the basic education system during the child's stay, highlighting the needs of vulnerable people (defined in the Directive as including children)

- Article 17 detention should only be a 'measure of last resort' for the 'shortest appropriate period of time' for unaccompanied minors and families with minors, and in the context of the child's best interests.

Moreover, according to Article 8(6), 'Member States shall provide for an effective forced-return monitoring system.' The 2017 Annex to the Return Handbook notes that this obligation holds through the reception of the returnee into their country. ${ }^{78}$ This last point is important considering the absence of monitoring systems for arrivals in Afghanistan or their inefficiency due to security issues and a lack of resources. $A$ recast returns directive is currently under negotiation.

While the Return Directive applies to 'all EU countries except Ireland and the United Kingdom and the following non-EU Schengen Area countries: Iceland, Liechtenstein, Norway and Switzerland', 79 it has been insufficiently transposed into national legal frameworks. ${ }^{80}$ To address this gap, it has been complemented by a Return

\footnotetext{
Ktistakis,Y. (2013) "Protecting Migrants under the European Convention on Human Rights and the European Social Charter:A handbook for legal practitioners", Council of Europe. https://rm.coe.int/168007ff59

Save the Children report Keeping children at the centre - Time for EU solidarity inprotecting migrant and refugee children's rights, 2017

77 DIRECTIVE 2008/115/EC OFTHE EUROPEAN PARLIAMENT AND OFTHE COUNCIL of 16 December 2008 on common standards and procedures in Member States for returning illegally staying third-country nationals,

80 Marie Walter-Franke, in "Asylum Detention in Europe: State of Play and Ways Forward" Jacques Delors Institut, May 18, 2017, specificies "While the adoption of EU rules on detention has had a measurable impact, questionable practices persist, due to deficient enforcement and to the vagueness, parsimony and built-in flexibility of EU rules that allow the continuation of a wide spectrum of policies." p. 16
} 
Handbook. ${ }^{81}$ Originally published in 2015, with guidance on how to implement the directive and a number of safeguards for children, it was updated in 2017. The Handbook acknowledges that return is only one option and that any Member State action must consider the 'best interests of the child'. It further underlines the need for adequate reception for unaccompanied minors in the state of return. Article 10(2) specifies that reception by the police in the country of return without the necessary follow-up measures cannot be considered 'adequate reception'.

\section{On the Afghan side: National laws and institutions}

The Ministry of Labour, Social Affairs, Martyrs and Disabled (MoLSAMD), alongside the Ministry of Refugees and Repatriations (MoRR), are leading efforts to coordinate a support system for returning children and young people. Responsibility for unaccompanied child returnees is shared between the two ministries, with insufficient resources and a lack of information and data.

Although Afghanistan benefits from a well-developed set of laws and policies relevant to children (Table 2), most focus on (1) security and violence, (2) economic and social protection and (3) solutions to displacement. Missing from this list is specific guidance or a directive on the return and reintegration of children.
Table 2: Afghan laws and policies relevant to children

\begin{tabular}{|c|c|}
\hline National Law/Policy & Year \\
\hline Constitution of Afghanistan & \multirow{3}{*}{2004} \\
\hline $\begin{array}{l}\text { National Plan of Action against Trafficking } \\
\text { and Kidnapping of Children }\end{array}$ & \\
\hline National Strategy of Children at Risk & \\
\hline The Juvenile Code & 2005 \\
\hline The Labour code & 2007 \\
\hline $\begin{array}{l}\text { Law on Counter Abduction and Human } \\
\text { Trafficking }\end{array}$ & \multirow{4}{*}{2008} \\
\hline $\begin{array}{l}\text { National Strategy for Children with } \\
\text { Disabilities }\end{array}$ & \\
\hline National Justice Sector Strategy & \\
\hline The Education Law & \\
\hline $\begin{array}{l}\text { National Law for the Rights and Privileges } \\
\text { of Persons with Disability }\end{array}$ & 2009 \\
\hline Shia Personal Family Law & $2009 / 10$ \\
\hline $\begin{array}{l}\text { Elimination of Violence against Women } \\
\text { (EVAW) }\end{array}$ & 2010 \\
\hline $\begin{array}{l}\text { Action Plan for the Prevention of Underage } \\
\text { Recruitment into the Afghan National } \\
\text { Security Forces }\end{array}$ & \multirow[t]{2}{*}{2011} \\
\hline $\begin{array}{l}\text { National Strategy for Street Working } \\
\text { Children (2011-2014) }\end{array}$ & \\
\hline $\begin{array}{l}\text { National Policy on Internally Displaced } \\
\text { Persons (IDPs) }\end{array}$ & 2014 \\
\hline National Labour Policy (NLP) & 2016 \\
\hline $\begin{array}{l}\text { National Policy Framework for Returnees } \\
\text { and IDPs }\end{array}$ & \multirow{2}{*}{2017} \\
\hline $\begin{array}{l}\text { National Return and Reintegration } \\
\text { Strategy }\end{array}$ & \\
\hline
\end{tabular}

\section{Joint Way Forward}

The outcome of negotiations between the EU and Afghanistan, the Joint Way Forward (JWF) is an agreement whose objective is to '[pave] the way for a structural dialogue and cooperation on migration issues, based on a commitment to identify effective ways to address the needs of both sides'. More practically, this document frames the return of Afghans whose asylum application has been rejected by EU Member States. 
The JWF provides for the technical aspect of the return, such as the organisation of flights, proof of nationality and flight costs. It was signed on 2 October 2016 and went into action for a renewable period of two years. The document overall makes it easier to forcibly return Afghans to Afghanistan including children once they turn 18, without the considerations discussed above..$^{82}$ This agreement has been denounced by human rights organisations as the organised deportation to an unsafe context, violating the non-refoulement principle. ${ }^{83}$ The agreement makes no specific mention of best interests or best interests procedures. It states that 'special consideration will be given to the needs of women, children and other vulnerable groups in the development and implementation of the reintegration programmes'.

\section{Facilities as adequate reception for unaccompanied children in Afghanistan}

To date, unaccompanied children have only been returned from Europe to family or relatives in Afghanistan.

Reception facilities and institutions have so far not been used.There have, however, been attempts by governments to set up such facilities. Stakeholders involved in this research flagged up that this is currently being discussed with Norway and Denmark, ${ }^{84}$ And the Norwegian Minister of Justice stated in a newspaper article that they are hoping to finalise agreements shortly. ${ }^{85}$ Setting up such facilities would enable European countries to return unaccompanied children by force and in cases where family members have not been traced. Article 10 of the EU Returns Directive gives little guidance on the criteria of 'adequate facilities'. However, setting up such facilities in Afghanistan is neither appropriate nor in line with child rights safeguards. First, children should only be returned when in their best interests. Secondly, facilities are generally not in the best interests of a child and there needs to be a guardianship system put in place following all safeguards as listed, for example, in the CRC's General Comment No. 6.

\section{CASE STUDY}

19-year-old girl, who was 18 when she returned voluntarily with her family from Bulgaria

-19-year-old girl, who was 18 when she returned voluntarily with her family

- Country of return: Bulgaria

- Reason for migration: Security

- Migration history:Travelled with her parents and siblings

- Return status: Returned voluntarily with her family

- Future plans:Wants to study
and re-migrate legally

Life was too difficult, we decided to return when my father took this decision, we were all in agreement as we couldn't bear any more difficult: we neither had money, savings, housing, assets to continue. After one year and eight months we were back in Kabul. But this time with no money or housing. As soon as we landed, I remembered that we have nothing else left - no money, no hope.

My only happiness was that we were still all together.We are still healthy. I have a constant feeling of fear and danger.We are not allowed to go out and be free. I don't even show myself in front of our relatives. We keep to ourselves. I would feel more integrated if there is security and employment for my mother and father. Currently I am scared of insecurity and kidnappings. We have relations with our close relatives but due to our fear of threats and kidnapping we are not very interested in getting in touch with people. My future plan is to go to Europe through legal means if possible.

\footnotetext{
82 The Joint Way Forward specifically notes that it "identifies a series of actions to be taken as a matter of urgency by the EU and the Government of Afghanistan with the objective to establish a rapid, effective and manageable process for a smooth, dignified and orderly return of Afghan nationals who do not fulfil the conditions in force for entry to, presence in, or residence on the territory of the EU, and to facilitate their reintegration in Afghanistan in a spirit of cooperation."

83 “Forced Back to Danger",Amnesty International Report, October 2017

4 See for example https://bit.ly/2CwXn4p

${ }^{85}$ https://bit.ly/2pLdUJA
} 


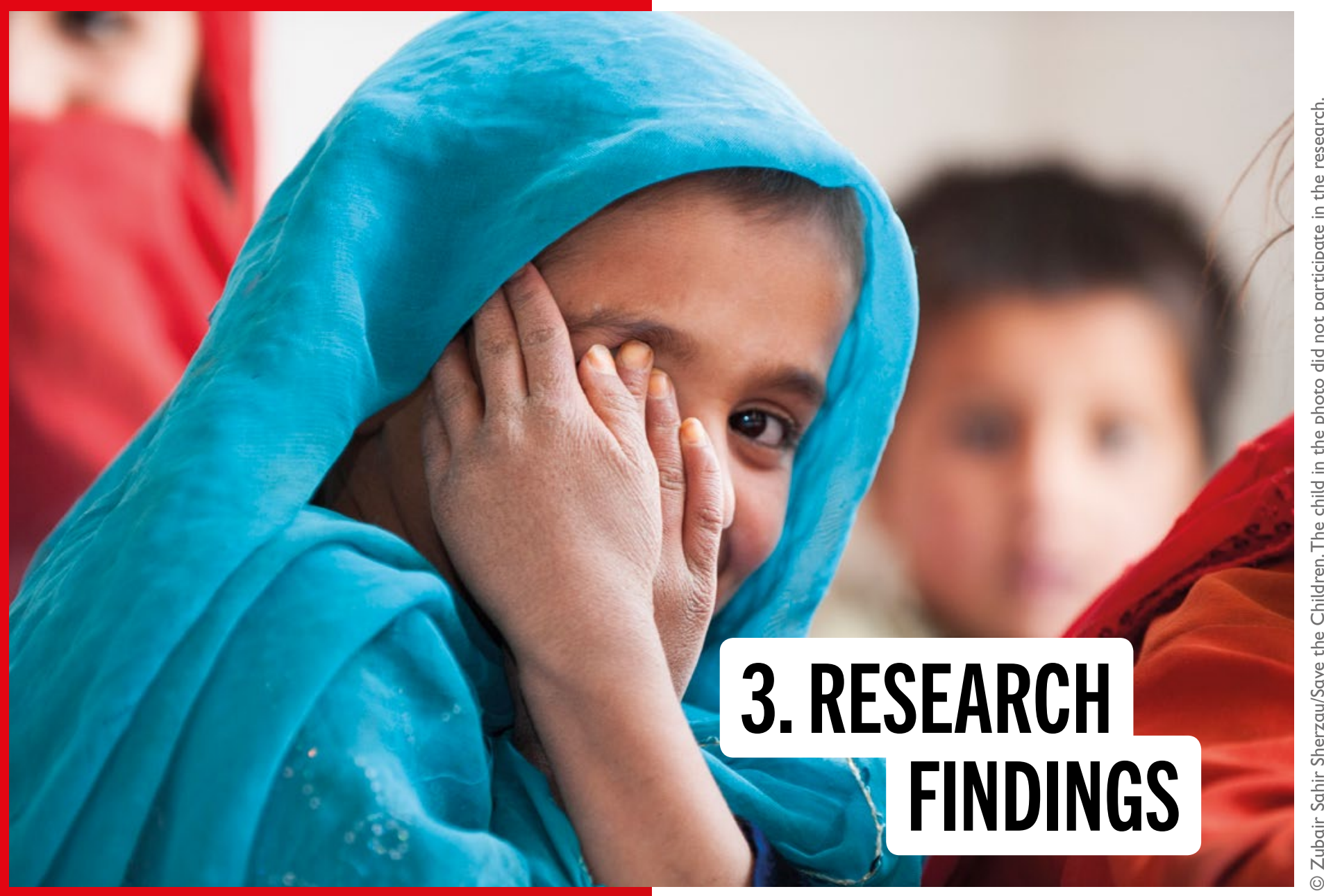

This chapter details the research findings both from the experiences of children returned to Afghanistan and focus group discussions conducted with children in Sweden and Norway about their concerns related to return. It focuses on the experiences of children and parents based on questionnaires and case studies, examining how children's rights are considered in returns procedures and what the conditions for return and reintegration are upon arrival in Afghanistan. The research also considered children's support needs and whether or not these are met before, during and after return.

\subsection{THE JOURNEY TO EUROPE}

Throughout the case studies, as well as in the discussions in Sweden, parents and children spent more time than expected discussing the experiences they had had on their way to Europe. Examining these journeys shows that, of the $\mathbf{5 7}$ children, eight were born in Iran or Pakistan and had never been to Afghanistan. ${ }^{86}$ Return and (re-)integration have different meanings for these children as they prepare to set off to a country that has never been home.

As there are almost no regular routes to reach Europe - including for those seeking international protection - the journey is often difficult and traumatic, resulting in a high need for psychosocial support. All the children recounted hunger, thirst and fear of death, while some spoke of witnessing death. The children's visual memories remain intact years later, ${ }^{87}$ according to a girl in Herat.

86 For more information on Iran-born Afghans, see Second-generation Afghans in Iran: Integration, Identity and Return, AREU,April 2008

87 Monish Bathia speaks of ongoing distress to reflect on the layering of trauma and stress that accumulate and continue to impact the wellbeing throughout a migrants' life. Bathia, M (2018) Mental Health and State Violence in the Asylum Process, https://bit.ly/2IMTYyL 
66

The fourth time it worked, we managed to make it to Greece and continue our trip. We saw many children on other boats, including another boat that sunk. We had spent two hours in the water when I saw that. I was completely shocked when I witnessed this. I was convinced our boat would sink too and we would drown, without anywhere to rescue us. I still vividly remember this scenery - they were all screaming, and no one was there to save them. At night, I would always re-live this moment and I would not be able to sleep anymore. I then re-lived all the difficulties - the forests we had to go through, my shoes ripped apart, I had to travel through the snowy mountains bare foot, until the drowning of this boat"

15-year-old girl returned from Greece

Some families and children avoided crossing the sea because of accounts they heard about deaths at sea. For these families, who went through the forests and woods, the journey lasted longer, on average one month.

66

The first thing I saw was a dead, torn, open human body, with clothes full of blood. My sister was screaming and saying 'animals will eat us'. My mother tried to reassure us, but I never thought we would make it alive"

19-year-old girl returned from Bulgaria

At the other end of this journey was Bulgaria, where instances of detention and trafficking were mentioned by children. In Sweden, parents raised concerns about the effects of the journey on theirchildren. One spoke of her daughter having nightmares from and never wanting to set foot on a boat again. ${ }^{88}$

Specific protection concerns reported by children along the journey include:

- Food deprivation, often eating five times a week or at best once a day

- Sleep deprivation and exhaustion, with five minutes of rest every eight to ten hours
- Walking across difficult terrain, often spending nights sleeping outside in the woods and in the mountains

- Physical abuse, ill treatment and beatings

- Shootings in border areas

- Theft and petty criminality

- Abduction

- Detention, notably in Turkey, Bulgaria and Hungary

- Family separation.

\subsection{RETURN PROCEDURES AND SAFEGUARDS}

\section{Participation of children in procedures}

\section{THE RIGHT TO BE HEARD}

Article 12 in the the UNCRC states:

States Parties shall assure to the child who is capable of forming his or her own views the right to express those views freely in all matters affecting the child, the views of the child being given due weight in accordance with the age and maturity of the child.'

UNCRC, art 12.1

The research reveals that of the $\mathbf{5 3}$ children who completed questionnaires, 33 stated that they were not involved in the decision to return and that other safeguards related to the procedure were not followed. ${ }^{89}$ This can be considered at two levels:

1. The official level.A follow-up question in the survey confirms that several children were not heard officially. Only 35 of the 53 children reported being interviewed as part of status/asylum proceedings. ${ }^{90}$ Parents in Sweden further expressed concern about how children were involved. They felt that interviewers were asking questions that were inappropriate and questioning the children about the route rather than focusing on their needs and views. ${ }^{91}$

\footnotetext{
Parent FGDs in Norberg, Sweden

The question asked, "Were you involved in the decision to return?"; it did not distinguish between involvement at the familial or official level.

90 A distinction here must be made between those returned as unaccompanied children - all of whom were interviewed, although not all reported involvement in the decision - and other types of children returned.

91 Specifically, parents in FGDs in Norberg, Sweden, noted that they felt questions were asked in a way that was not child-sensitive, implying that families were lying, and that in some cases interviews with children lasted too long.
} 
Figure 3: Were you interviewed as part of the decision to return?

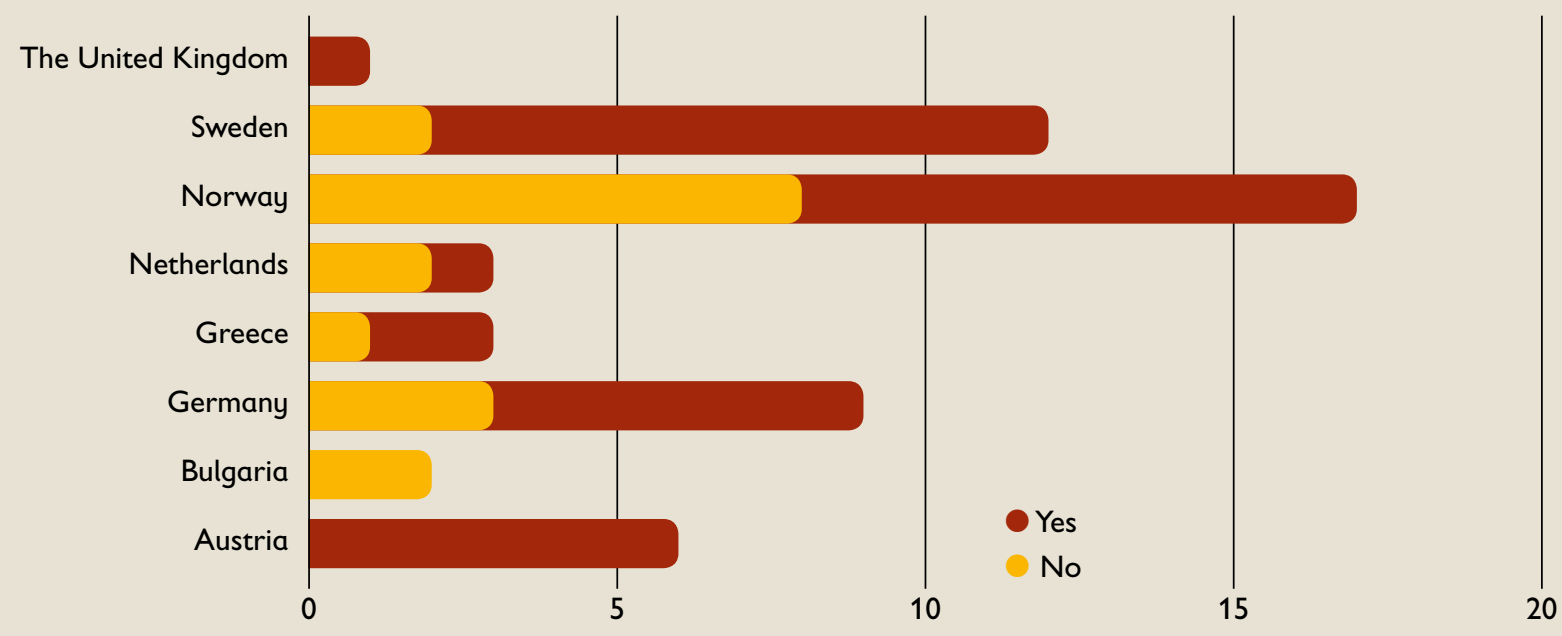

Further safeguards to ensure that the voices of children can be effectively heard are inconsistently applied and procedures are not always child-sensitive.

They [the authorities] were treating me like a criminal"

18-year-old boy returned from Norway when he was 17

2. The familial level. Several case studies underlined situations where the decision to return was taken by parents against their children's wishes.

\section{6}

We were very happy with how we were treated in camps. Until my mom said that she could no longer live here. She said life in the camp was too difficult for her. [...] No one asked me - or my younger brother - if we were satisfied with the idea of going back to Afghanistan. No one consulted us. If they had asked me, I would have told them that I did not want to go back, that I was not satisfied. I did not want to live in war anymore. [...] After a few days my father decided to return us all. I was very saddened by this decision. I did not want to leave Germany"

14-year-old boy returned from

Germany when he was 12
66

My father was not happy, and he was losing hope. He used to say, 'The borders have been closed, we will not be able to travel easily through the next borders and make it to Germany.' For this reason, my father decided one day that we should return to Afghanistan, all together. When I heard this decision, I became extremely sad and anxious. I tried very hard to explain to my father that I did not want to live in Afghanistan any longer, that I wanted to live where we were, that I wanted to progress, study...but my father only listened to himself and did not pay attention to what I had to say. I asked, I begged, I cried, I told him, "I do not want to go back to Afghanistan,' but no one listened to me"

15-year-old girl returned from

Greece when she was 14

66

My father said, I can't leave you here alone. [...] I did not agree with my father's decision because I had begun adjusting there and my school lessons were going nicely and I was learning well. I had no intention to return to Afghanistan, but my father brought me by force. Returning back to Afghanistan was actually accepting an evil because it is an insecure country"

20-year-old girl returned from

Austria when she was 18 


\section{Forced or voluntary return}

This report considers both voluntary and forced returns of children.Voluntary returns include so-called voluntary departure and withdrawn asylum applications. Of the $\mathbf{5 3}$ children who completed questionnaires, 23 stated that their return was voluntary (see Figure 4).

The concept of voluntary returns can be challenged for several reasons. The option to leave by voluntary departure after a rejected asylum application is not considered truly voluntary by children and families interviewed in Sweden. ${ }^{92}$ In 38 cases reviewed in this research - including some where children stated that they felt the return was voluntary - they subsequently considered not returning to Afghanistan after the initial decision. There can be up to a year between the voluntary decision to return and the actual return, during which time a person might change their mind or there may be changes in the home country's security situation.

The majority of those who returned voluntarily felt that they had been involved in the decision to return but the opposite was true for those whose return was not voluntary. ${ }^{93}$

\section{Family reunification requires further planning and follow-up}

The Return Directive gives clear safeguards for the return of unaccompanied children, especially around reception:'before removing an unaccompanied minor from the territory of a (Member) State, the authorities of that (Member) State shall be satisfied that the child will be returned to a member of his/her family, a nominated guardian or adequate reception facilities in the country of return.'

Articles 9 and 10 of the UNCRC outline a child's right to live with their parents, unless a separation is in the best interests of the child, and to reunite with them when living in separate countries. Best interests procedures require family tracing and an assessment of reception situation, to ensure that it is 'suitable and safe'. ${ }^{94}$ Yet, when
Figure 4: Did you return voluntarily?
28

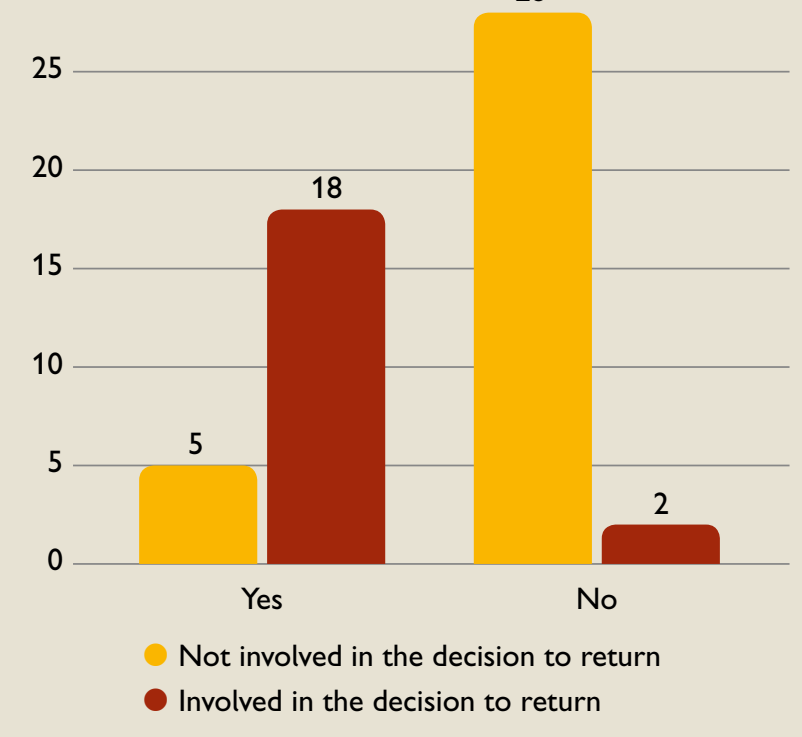

asked, only one child returned unaccompanied under the age of 18 stated that the authorities abroad contacted someone from their family prior to return. Four more said they did so themselves and the rest did not know or said that no one had been contacted. Only one child returned under 18 alone reported someone having visited their home prior to return. While this is a small sample size, and children interviewed may not have been aware of procedures, this is a finding of significant concern, as it suggests that key durable solutions safeguards are not being followed. Governments are not fulfilling their responsibilities prior to return. The potential impact of return on a family - and conflicting priorities that families returning together may face - requires actual follow-up after return of the child to validate that BID processes are being effectively conducted, and that the best interests of children are considered even when returning with their families. ${ }^{95}$ Key informants flagged the potential, for example, of in-kind support meant for educational fees being diverted to other purposes such as the purchase of a car for the family. ${ }^{96}$ Children who did not wish to return but were obliged to because of parental decisions may also face tensions within the family.

\footnotetext{
22 This opinion was shared by unaccompanied young people, parents and CSOs in Sweden consistently throughout consultations conducted.

93 This decision was made with Save the Children to allow the children involved, rather than external perception, to define voluntariness; additionally, children, especially those in families, may not have been aware of the specifics of their return (voluntary or forced). The perception of children is key to understanding the potential for durable solutions. UNHCR/UNICEF, in Safe \& Sound:What States can do to Ensure Respect for the Best Interest of Unaccompanied and Separated Children in Europe", UNHCR/UNICEF, identify sustainability and voluntariness as components to a durable solution.

4 The protection of Children in Migration EC COM (2017) 211.

95 Article 5 of the EU Returns Directive specifically notes that "When implementing this Directive, Member States shall take due account of: (a) the best interests of the child; (b) family life; (c) the state of health of the third-country national concerned and respect the principle of non-refoulement.' While this only applies to EU Member States, the best interests principle is enshrined in Article 3 of the UNCRC.

96 Key informant interview with the Afghan Center for Excellence in March 2018
} 
THE SITUATION OF UNACCOMPANIED

CHILDREN AND YOUNG PEOPLE

Throughout the consultations in Europe unaccompanied children and young people highlighted age assessments and temporary protection of different types as particularly stressful. Norway offers temporary stays to unaccompanied children with rejected asylum claims, meaning that they can stay in the country until they are 18 , and then be deported. As young people are no longer formally children they can be returned without family being there to receive them. The young people interviewed in Norway all had issues relating to their mental health, such as depression, insomnia and anxiety.

In the consultations in Sweden, young people mainly talked about age assessments, and how they experience them as arbitrary, unfair and incorrect, as well as how support disappears from one day to the next as soon as they turn 18. They associate turning 18 with deportation. Even for children who had been granted a status, these are often temporary.Young people spoke of never feeling entirely safe and noted that the long waiting times make people sick. The asylum process in Sweden can take several years and temporary permits can last for just 13 months. In 2017, there were 12 cases of unaccompanied children committing suicide in Sweden. The majority were from Afghanistan and were waiting for an asylum decision. ${ }^{97}$

\section{Safety in the returns process}

Of the 53 children who completed questionnaires, 29 did not feel safe in the returns process, including ten who identify their return as voluntary (Figure 5). Over half of the children report instances of violence and coercion in the return process. ${ }^{98}$ While 12 reported coercion and six reported violence, an additional nine children were exposed to both violence and coercion.
66

We were arrested with my mother and my siblings. My father was arrested the next day. They moved us to the deportation centre for one day. The next day at 9 am we were deported. They took our phones, we could not call our lawyer. The police said because you were supposed to leave the country and you did not, this is why we are deporting you"

12-year-old boy returned from Norway

Guidance around returns developed by the EU's Fundamental Rights Agency notes that:'Removals should not involve dawn raids, or interventions at or near educational, health, shelter, religious or other premises' ${ }^{\prime 9}$ and that "Children and families shall not be detained or separated from their parents by immigration detention at any point during the process due to their status or that of their parents. Non-custodial community-based alternatives should be used for the whole family.'100

However, forced returns are often accompanied by the intervention of the police to escort families and children out of their temporary European homes. A child in Norway, who had experienced attempted forced return to Afghanistan, stated that the police held her by both arms and legs. ${ }^{101}$

66

I couldn't breathe. I felt like I was going to die. I was put in a separate car from the rest of my family. I was so scared! My situation was very bad! I asked those who were driving if they could stop the car so that I could get out and kill myself."

Girl, aged 14, arrested to be deported but the deportation was stopped when they reached the airport

For children and families, returns can involve detention and family separation, much like their experience of migration to Europe, and much like the experiences at

\footnotetext{
Survey commissioned by the National Board of Health and Social Affairs in Sweden, https://bit.ly/2CVUKKK

98 Specifically, children were asked, "Was violence or coercion involved at any point in the returns process"

99 As per guidance of the EU Fundamental Rights Agency ("Apprehension of migrants in an irregular situation - fundamental rights considerations"), also in the Return Handbook, the European Commission against Racism and Intolerance (ECRI) (General Policy Recommendation No. 16), and others.

100 For more information see: UNHCR, UNHCR's position regarding the detention of refugee and migrant children in the migration context, January 2017, available at: http://www.refworld.org/docid/5885c2434.html and Options Paper 1:Options for governments on care arrangements and alternatives to detention for children and families, 2015, available at: http://www.refworld.org/docid/5523e8d94.html; International Detention Coalition, Captured Childhood: Introducing a new model to ensure the rights and liberty of refugee, asylum seeker and Irregular migrant children affected by Immigration detention, 2012,Available at: http://www.refworld.org/ docid/510a604c2.html; and UNHCR, Options Paper 1: Options for governments on care arrangements and alternatives to detention for children and families, 2015, available at: http://www.refworld.org/docid/5523e8d94.html.

101 Save the Children consultations in Afghanistan.
} 
Figure 5: Did you feel safe

in the returns process?

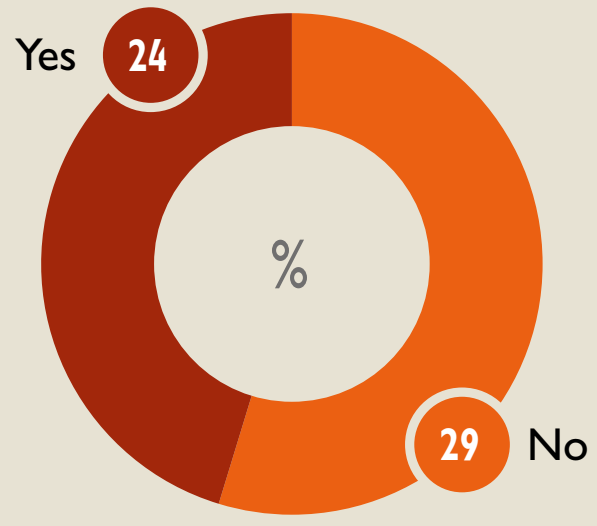

Figure 6: Was violence or coercion involved in the return process?

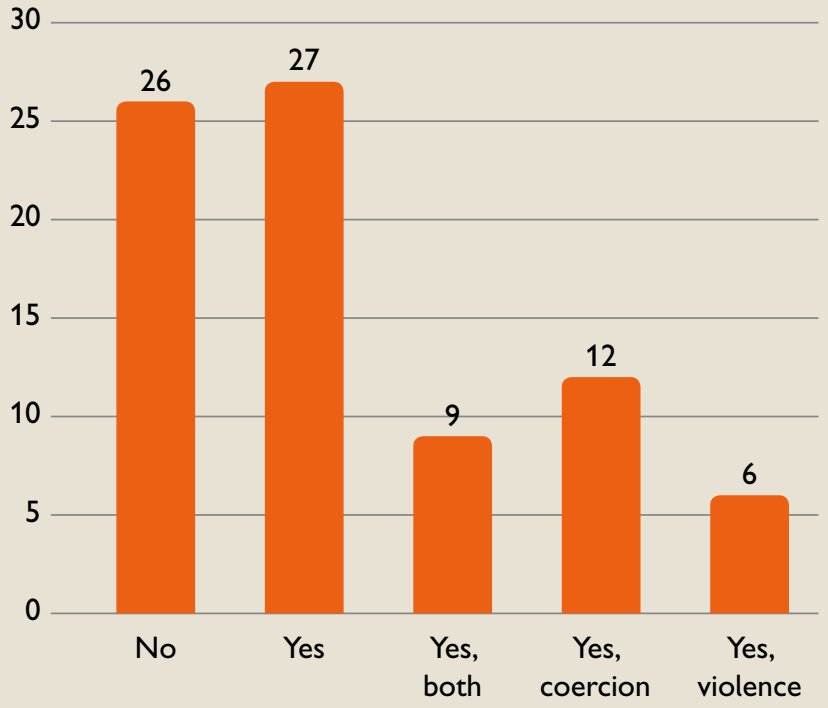

other border areas around the world. ${ }^{102}$ At these places, there are institutional representatives who can and do reach out to children. One boy interviewed explains,

\section{6}

We did not receive any kind of help or information. We were just taken back to Afghanistan. The police brought us to the airport. They were 11 to 12 police officers who came with us to Russia (some of them left there) then to Dubai (some left again there) and then to Kabul."

19-year-old boy returned from Norway when he was 17

\section{Limited support during the returns process}

Children receive very little child-specific support, and practices in the support provided by European governments and their service providers varied. While proper implementation of UNCRC safeguards to ensure child-friendly returns requires 'appropriate support and assistance', ${ }^{103}$ in actuality, a number of children of the 53 who completed questionnaires reported returning alone $(10)^{104}$ or accompanied by police (16). While most children received some type of pre-return support (41 of the 53), 13 of the 17 parents interviewed who had also returned from Europe confirmed that they had received cash (34), travel costs, transportation (21) and documentation (eight). Many children had questions about what would happen to their schooling - with few benefiting from educational transfers, and these seemingly on a more ad hoc basis. Most importantly, only three children interviewed spoke to representatives of organisations in Afghanistan, and only three received a specific reintegration plan.

Table 3: Pre-return support reported

\begin{tabular}{l|r|}
\hline Documentation & 8 \\
\hline Travel costs/Transportation & 21 \\
\hline Accommodation before departure & 6 \\
\hline Accommodation on arrival & 3 \\
\hline Counseling/Information & 1 \\
\hline Cash & 34 \\
\hline We spoke to representatives & 3 \\
\hline of organisations in Afghanistan & 3 \\
\hline Specific reintegration plan & 3 \\
\hline Other (specify) & 1
\end{tabular}

\footnotetext{
102 Family separation has been conducted at the US-Mexico border as well as for migrants trying to reach Australia. For more information see Addressing The Pain of Separation for Refugee Families, Refugee Council of Australia, November 2016 and The Trump administration's separation of families at the border, explained,Vox, June 15; 2018

${ }^{103}$ Necessary Provisions document, p. 18 in draft

104 Of which five were unaccompanied minors and five were returned as 18-year-olds.
} 
This defies procedural safeguards around returns, which call for children and families to be provided with information on the procedure throughout, and the stated needs of parents, who noted in Norway, for example:

We received information regarding financial support and related matters, but otherwise we have not received any separate information (regarding return). We did not flee because of financial difficulties. Our problems are political."

\section{6}

In the plane we were accompanied by policemen. My brother was handcuffed, he was just 15 or 16 at the time. The police treated us respectfully. No one welcomed us at the airport. Someone just put us into a car and sent us to a center of the ministry, note sure which ministry. It was two years ago but I don't remember the exact date. I don't think we received any support. When we returned, we did not have any family or friends to help us. My main concerns before returning were security and freedom"

16-year-old girl returned from Norway when she was 13

Figure 7: Who returned to Afghanistan with you?

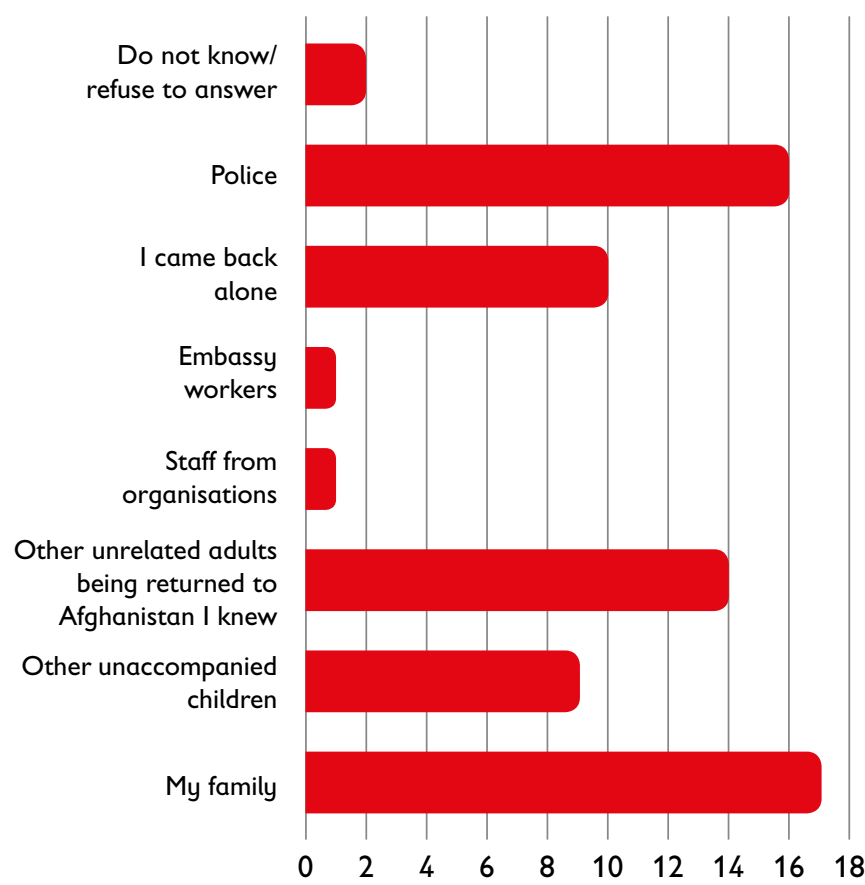

THEVOICES OF CHILDREN AND YOUNG PEOPLE IN SWEDEN AND NORWAY - IMAGES OF AFGHANISTAN

The next section examines fears and risks associated with return, as voiced by children and young people in Norway and Sweden.

On physical safety, beyond the risks of generalised violence, children spoke about specific persecution and threats against them. These were due to the presence of personal enemies and broader threats of kidnappings and to the impact of Westernisation.

\section{6}

It's not just about war. Chidlren are kidnapped, including for bacha bazi. The police - everyone - is bigger than you. [...] You are a child, so you can't protect yourself."

They were aware of the stigma that comes with having spent time abroad, and of questions they would be exposed to around their religious beliefs and practices.

66

If you have lived in Europe, you are not considered an Afghan. You are not a Muslim anymore.You are an infidel (kafir) and you have to be killed."

Older children were concerned about the risks of recruitment to armed groups.

\section{6}

It's not easier to return to Afghanistan when you turn 18 years old. In fact, there are bigger problems for adults in Afghanistan. This is because there is a bigger chance of being recruited for the Taliban when you are older."

Girls and boys believed they were more vulnerable than adult returnees because of their age. They spoke of the practice of Bacha bazi, of gender-based and sexual violence, and of child labour and child marriage, that are common in their locations. They also emphasised the lack of voice and rights for children, broadly and especially girls. 
Bacha bazi is a big reason that makes people flee. Children are taken as slaves. In some provinces especially, little/small children are taken, they pay the families."

\section{My uncle had a 13-year-old daughter.}

She had been forcibly married. I asked my mother, why, she is so small! She replied, because there is war, and because they are unable to care for all their children and to provide them with food and clothing."

\section{6}

Children can't decide for themselves. Family is the main person, that decides everything. Education, if you can have a cell phone or not. Children should pray, be religious, children are forced, beaten if they don't go to the mosque. According to the religion, parents can beat their children."

\section{6 \\ There is no respect for girls, women can't go to the bus, can't drive, you have to be home not to be raped."}

They spoke specifically of ethnic and religious discrimination, against the Hazara and Shia religious minorities specifically, as well as around the practice of religion more broadly.

\section{6 \\ If you kill one Shia then you will go to paradise; if you kill seven Shia you will get a fork and eat with Mohammed in paradise.This kind of view is a problem."}

Young people were then prompted about their material safety and legal concerns. On the latter, not being able to rely on the police to protect them due to corruption or brutality was a main barrier to the rule of law; and not being able to rely on government authorities to find one's family, for unaccompanied minors, meant that return would not be a return "home."

In Afghanistan, there is no authority to help you find your family."
On the former, the lack of employment, housing and education for all children but especially for girls, and health care were the main gaps that they knew they would return to. These are the very services that they can access in Europe, which are not available in Afghanistan for them.

66

When a family is returned, women and children are the most vulnerable. The man will try to gain an education and find a job, but this is often not feasible. The man is then unable to provide, boys are unable to get an education, and girls are often forcibly married."

Girls and boys were conscious that negative community perceptions would be an obstacle to their reintegration and their social mobility upon return. They feared discrimination, isolation and marginalisation, worsened by lack of networks. They feared not being able to talk to anyone about these or to receive psychological support. They knew they would not be able to access schools like other children in their locality.

66

Most people do not have any family in Afghanistan. Most of us have family in Iran, or in other places. There is nowhere to stay and live in Afghanistan. What to do? Sleep in the streets?"

Girls and boys were finally aware that the structural problems that caused them to leave in the first place would still be waiting for them upon return.

\section{Girls cannot choose for themselves. When} we are 14-15, we have to marry. When I lived in Afghanistan, I was not allowed to go to school. Because I was a girl. You can't because you are a girl."

As the next section will show, these fears are warranted. Children have very little mobility outside of their immediate microsystem or of their homes. The lack of interaction, of schooling and socialisation through schooling, means that their psychosocial needs increase after return. Faced with rejection in the asylum system, that rejection continues upon return and is felt as an injustice given the exposure that they had, in Europe, to greater mobility, even within the camps. 


\subsection{CONDITIONS FOR RETURN AND REINTEGRATION IN AFGHANISTAN}

Save the Children has developed a Child-Sensitive Durable Solutions Framework (CSDSF), ${ }^{105}$ which underlines that durable solutions are a process, recognising that reintegration encompasses multiple, non-sequential dimensions. The CSDSF defines four main criteria for child-sensitive durable solutions - Material Safety, Physical Safety, Legal Safety, and Mental health and Psychosocial Safety. The elements explored below take a rights-based approach to understanding the return of children to Afghanistan along these four criteria by considering whether the rights accorded by the UNCRC along each of these are being respected.

\section{Physical safety: High real and perceived risks}

\section{Children are coming back to an environment that is very hostile, more hostile than when they left."106}

Nearly all children and parents interviewed in Sweden and Norway named security as a major risk they would face on return. Parents in a focus group in Sweden in February, for example, specifically noted the broader situation in Afghanistan, forced recruitment and threats from armed groups as real concerns. This research confirms the reality of these concerns.

\section{THE UNCRCAND PHYSICAL SAFETY}

Article 6 of the UNCRC recognises the right of children to survival, while Article 38 recognises that governments must protect them from conflict and war, and specifically prohibits recruitment of children under 15. ${ }^{107}$ Article 37 states that no child shall besubject to torture or other cruel, inhuman or degrading treatment or punishment, or unlawful detention.

\section{Insecurity of surroundings}

Children face both real and perceived insecurity on return. OCHA notes that 'children continue to be disproportionately affected by the conflict. ${ }^{108}$ In the first half of 2018, according to the United Nations Assistance Mission in Afghanistan (UNAMA), civilian deaths hit a 'record high', and casualties (including injury) continued on a par with 2016 and 2017 numbers. Of these casualties, 1,355 were recorded as child casualties (including 363 deaths). Schools were increasingly targeted by anti-government elements. ${ }^{109}$ The report further notes that civilians living in Kabul, Nangarhar, Faryab, Helmand and Kandahar were most affected, with 321 killed and 672 injured in Kabul province. ${ }^{110}$

Few children reported arguments between themselves and members of their household. ${ }^{111}$ Neither children nor parents interviewed generally feel secure outside when engaging in daily activities (see Figures 9 and 10). Some returnees were not in their families' province of origin, potentially placing them at additional risk, as they then have more limited networks and may be more vulnerable.

Asked why they do not feel secure, 16 of the 21 parents cited 'problems because the child has lived abroad'. One child said:

66

Since returning, all of my family are trying not to draw attention from people. At school, I told the other students I returned from Iran. Outside, I don't speak Norwegian, for example when I'm with my brother. [...] We are very careful with our language, attitude, behaviour. We had to lie, I lied to my classmates"

19-year-old boy returned from Norway when he was 17

This danger is real: five of the parents interviewed reported that their child had been injured. Such security issues were flagged in both Herat and Kabul, casting doubt on whether these are safe zones for children.

\footnotetext{
See Chapter 2

106 Key informant interview with UNICEF Afghanistan in April 2018

107 CRC, UNICEF Factsheet on CRC. https://www.unicef.org/crc/files/Rights overview.pdf

The UNCRC's optional protocol on the involvement on children in armed conflict raises this age to 18.

${ }^{108}$ UN OCHA. December 2017. Humanitarian Needs Overview 2018:Afghanistan. Retrieved from https://bit.ly/2pUgf5n

109 Mid-Year Updates on the Protection of Civilians in Armed Conflict: 1 January to 30 June 2018, 2018,UNAMA, p.3

110 Ibid. pp. 1-2; No such data exists specific to returnees.

111 This could suggest that these children are better off than the average population; as a point of comparison the 2010-11 Afghanistan Multiple Indicator Cluster Survey found high acceptance of domestic violence, with 92 per cent of Afghan women believing their husband has the right to hit or beat them for at least one reason, and only 12.7 per cent of children 2-14 experiencing only non-violent discipline.
} 
Attempted forced recruitment to armed combat

Ten of the 53 children who completed questionnaires stated that someone 'attempted to recruit them to fight in combat, commit acts of violence, or otherwise engage with armed groups'. This includes all three types of returned children - unaccompanied, returned at 18 , and children returned with their families, and occurred both among those returned to Kabul and Herat. One child returnee from Europe subsequently went to Syria to fight. Born in Iran and having never lived in Afghanistan, he was returned to Afghanistan from Europe. Without family in Afghanistan, he quickly left for Iran, where he was recruited to go to Syria. From there, he eventually returned to Afghanistan again after falling seriously ill (18-year-old boy returned from Norway when he was 17).

Existing information on the topic is anecdotal but confirms the real threat of forced recruitment of children. UNAMA has verified the recruitment of 22 boys to armed conflict this year, and news articles have reported the recruitment of children to armed forces, both governmental and other. ${ }^{112}$ UNHCR lists protection from under-age recruitment - in line with the UNCRC as a child-sensitive understanding of sufficient persecution to form grounds for asylum. ${ }^{113}$

\section{Child labour}

Most of the returned children are too old to fall under the 'child labour' category, and only 15 work. One reported working for an NGO. However, for the majority of the 15 returned children interviewed who work (now all over 18), they do so in insecure, economically uncertain sectors: car washing, metal workshops, shop keeping, daily labour. More generally, children in Afghanistan are at a very real risk of child labour: the 2013-2014 Afghanistan Living Conditions Survey (ALCS) found that 46 per cent of boys aged 14 already work. ${ }^{114}$

\footnotetext{
See for example https://bit.ly/2v5211S and https://bit.ly/2b2r50B

Note that the 2018 Trafficking in Persons report by the US State department highlights that the Afghan National Army has enacted a policy which prohibits the recruitment of children, and has proactively prevented the recruitment of some of these, but yet still recommends that the GolRA "Cease the unlawful recruitment and use of children by Afghan security forces", suggesting the prohibition is not enough. p. 64 https://www.state.gov/documents/organization/282798.pdf

113 Guidelines on International Protection, Child Asylum Claims under Articles 1(A)2 and 1(F) of the 1951 Convention and/or 1967 Protocol Relating to the Status of Refugees, UNHCR, HCF/GIP/09/08, p.8

114 National Risk and Vulnerability Assessment (NRVA), Central Statistics Office, Afghanistan, 2014 p. 28
}

\section{CASE STUDY}

\section{8-year-old boy, who was 17 when he returned from Norway}

- 18-year-old boy, who was 17 when he returned

- Country of return: Norway

- Reason for migrating: Discrimination in Iran, lack of access to education, services

- Migration history:Travelled alone

- Return status: Deported

- Future plans:Wants to go back to Europe or to go back to Syria

They asked me about my destination in Afghanistan, but my family was still in Iran. The only persons I knew in Kabul were a person from a support organisation and a friend who had been deported one week before me. My 'return' to Afghanistan was the first time I ever went to Afghanistan.

After Kabul, I went to Iran, but I did not meet with my family: my father was thinking that I might have done something wrong to have been deported and was angry at me. As a result, me and two other decided to go to Tehran to register to go fight in Syria. We received 20 days of military training and were then moved to Syria and given guns.

I was in Syria for seven months, and the reason I returned was because I felt severely ill and could not fight any more. When I left the hospital, I left for Turkey because I wanted to go back to Europe. We were arrested right before the border by the Iranian border police, and then deported to Afghanistan.

There were times where I reached the conclusion that suicide is a solution to this situation. One of the reasons I had gone to Syria is that I was sure I would not survive there and thought dying in Syria was better than committing suicide. 
Figure 8: How would you rate the standard of the housing you live in today?

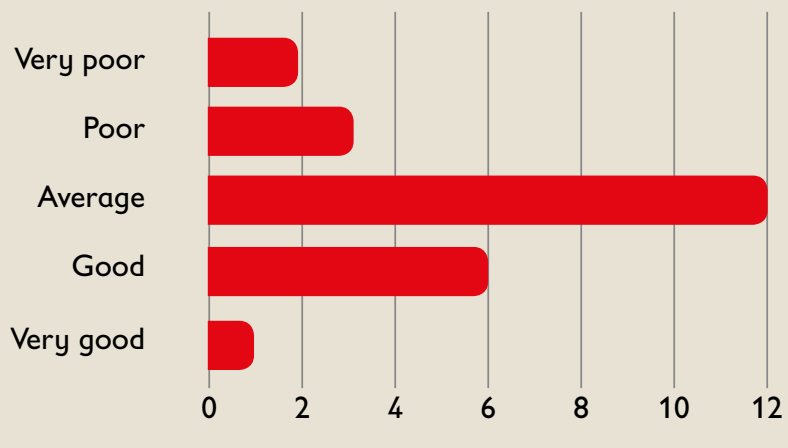

Figure 9: Do you feel secure for yourself and your family outside when engaging in daily activities?

(Returned children)

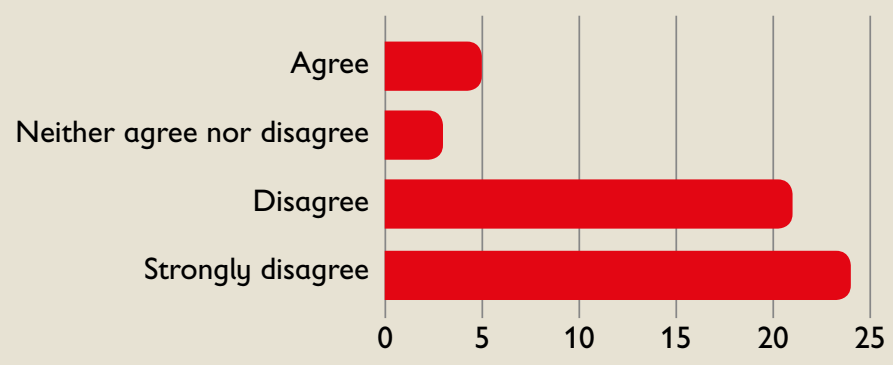

\section{Child marriage}

Only two of the children and young people interviewed are now married (one at 20, the other at 15). Two others are engaged. The fact that most respondents were boys likely contributes to this: according to the 2015 Demographic and Health Survey, 'while $45 \%$ of women marry by age 18 , only $11 \%$ of men marry that young'. ${ }^{115}$

\section{Material safety: Facing challenges common to all Afghan children}

The UNCRC details children's rights to health and health services, education and adequate standards of living (Art. 24, 28, and 27, respectively). These rights are not realised by a significant number of children in Afghanistan who are not returnees.

\section{THE UNCRC AND MATERIAL SAFETY}

Articles 23 and 24 articulate the rights of children to the best healthcare possible - to safe drinking water, nutritious food, a clean and safe environment, and information to help them stay healthy, and special care and support for children with disabilities. Article 27 confers the right to a standard of living 'good enough to meet their physical and mental needs', and Article 28 states that all children have the right to free primary school education and should be further encouraged to continue their education. ${ }^{116}$
As many as 3.7 million children are out of school in Afghanistan. ${ }^{117}$ As of 2010-11, only 56.7 per cent of the population uses an 'improved' source of drinking water; ${ }^{118}$ 31 per cent of the population uses 'improved' sanitation facilities; ${ }^{119}$ and 39 per cent of the population, in 2013-14, lived below the poverty line, with one-third suffering from food insecurity. ${ }^{120}$ This cannot be considered an 'adequate' standard of living, as it is insufficient to meet physical needs. The material situation reported by the returned children and their parents is - in relative terms - not worse than most inhabitants of their country but must be considered in absolute terms, confirming that children's rights are not being met (UNCRC Articles 23/24).

\section{Physical health}

Sixteen of the 24 parents interviewed - living in two of Afghanistan's most developed urban areas - said their household has access to health services. However, even when do, the quality is questionable. One respondent in Kabul reported that his sister had to wait two months for treatment for epilepsy. Nutrition is also a problem: all but two parents interviewed had to reduce the quantity or quality of food consumed for lack of means, and only four stated that they had to do so rarely.

Clearly, children's rights under Article 24 are not accorded. This is in line with conditions in the country as a whole: as of 2013 , only 45.5 per cent of the population used improve drinking water and nearly one-third of the Afghan population are severely to moderately food insecure. $^{121}$

\footnotetext{
115 Id., p. 63

${ }^{116}$ Fact Sheet,A summary of the Rights under the Convention on the Rights of the Child, UNICEF

17 Global Initiative on Out-Of-School Children -Afghanistan Country Study, UNICEF/UNESCO/Samuel Hall, Foreword, page 9

${ }_{118}$ Afghanistan Multiple Indicator Survey (AMICS), UNICEF 2011, p 68

119 Id., page 75

${ }^{120}$ NRVA, 2014, p. xxxi

121 Id.. Severely food insecure households have an average Kcal intake per person per day of 1,500 to 1,799, and moderately insecure households of 1,800 to 2,099 Kcal per person. Improved drinking water sources include "hand pump (private or public), bored wells, protected spring, piped water (private or municipal)"
} 
Figure 10: Do you feel secure for yourself and your family outside when engaging in daily activities Parents/guardians

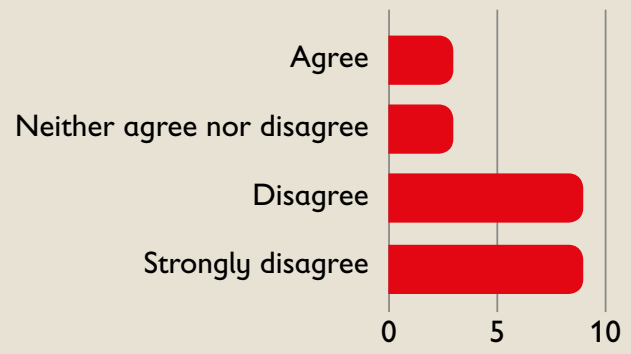

\section{Adequate housing}

Parents and guardians interviewed report average living conditions. Basic housing is generally available, with 49 of the 53 children who completed questionnaires reporting having electricity at home, 50 with access to piped water or a well, and 48 with access to an indoor or covered toilet. This reflects the urban focus of the research: 99.5 per cent of urban Afghans have access to electricity and 83.2 per cent use an improved sanitary facility. ${ }^{122}$

Access to housing is precarious and dependent on negative coping strategies. Most parents/guardians interviewed (16) rent their home, with only six owning it. This is in contrast to the Afghan population as a whole, of whom 89 per cent own the house where they live. ${ }^{123}$

Past research on IDPs has underlined how renting can lead to decreasing quality of housing as rising rents force households to seek out cheaper housing. ${ }^{124}$ One case study respondent in Herat noted that since returning his family has been sustaining itself through spending their savings and selling property to provide for daily expenses; the family's living conditions changed negatively after migrating to Europe. ${ }^{125}$

\section{Guardian presence}

Forty of the 53 child returnees live with a parent or a relative. Those who do not returned either as unaccompanied children or as 18-year-olds, and only one was under 18 at the time of the interview. Living with a parent or relative does not guarantee support. From a protection and support perspective, it is important to note that children may be disappointed by those meant to protect and support them.

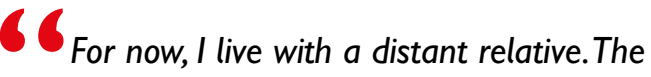
place is average. I don't like this situation. With this family member, I only live out of obligation, I have no other choice"

19-year-old boy returned from

Austria when he was 16

\section{Access to education}

Sixteen of the 53 children are currently in education, three at university level, with the youngest most likely to attend school. This is in contrast to the $\mathbf{4 5}$ children who studied while abroad. While several are now older and therefore less likely to be in school, this is still a steep drop-off and, in some cases, marks a stark contrast to life abroad. It is, however, in line with broader trends in Afghanistan, where 44 per cent of primary-aged children and 42 per cent of lower secondary-aged children are out of school. ${ }^{126}$

Other research confirms this challenge, noting that ' $[t]$ he most significant barrier faced by the young returnees has been the need to invest their time and energy into work to survive. Gaps in previous education, issues with certification of prior learning and the cost of study have also been prohibitive.'127

\section{$\checkmark 6$ Life in the camp [in Greece] is difficult, but} even there I was happier than living in my own country, with fear and without education. From 9 am to $11 \mathrm{am}, \mathrm{I}$ would attend school there [...] it gave me a great feeling since I have never been in school or studied in my life"

15-year-old girl returned from

Greece when she was 14

\footnotetext{
Afghanistan Living Conditions Survey (ALCS) 2016-2017, 2018, Central Statistics Office, p. ix

NRVA, 2014, p. 83

A Research Study on the Challenges of IDP Protection in Afghanistan, Norwegian Refugee Council/Samuel Hall, January 2018 page 6

125 Based on a case study conducted by the research team.

126 Global Initiative on Out-of-school Children, Afghanistan Country Survey, 2018, MoE (GoIRA), Samuel Hall/UNICEF

127 RSN, After return, p.32
} 
This highlights two areas for further support: first, the translation of educational documents from abroad and, secondly, the need to ensure access to documentation so that returned children can enrol in school. While European migration agencies recognise the importance of preparation in allowing children to return to school, noting the need to have documentation translated, ${ }^{128}$ in practice this is not occurring. Only five children reported having had this child-specific support. "Children must be linked to services - especially education. Any intervention without education does not make sense," underlined a UNICEF staff member in Afghanistan. ${ }^{129}$ Security risks of several types also threaten school attendance. Recent attacks on schools, including in Kabul, corroborate these concerns and make it more difficult for children returned from Europe, who already face an educational system challenged by structural limitations, to attend school. ${ }^{130}$

\section{6}

I have never attended school, I have never studied.

I always wanted to, but because of security problems, I have never been enrolled in school. [...] My father told me 'I am scared of someone kidnapping you, I cannot take this risk with you",

15-year-old girl returned from

Greece when she was 14

66

We are sitting in the class, but all the minds are on the door, because our school is under threat, because it is a girls' school"

16-year-old girl returned from

Norway when she was 13

\section{Economic situations}

Afghanistan's 2016-2017 Living Conditions Survey (ALCS) shows that poverty is more widespread today than it was immediately after the fall of the Taliban regime, and at the same time development aid has decreased. ${ }^{131}$

Ownership of key assets (fridge, stove, TV, mobile phone, etc) categorises most returnee households as relatively well off. ${ }^{132}$ Selling these assets is part of negative financial coping mechanisms and a sign of precarity. However, only 5 of 24 parents interviewed are satisfied with their current economic situation. Of those who work, 12 do so in poorly paid or unstable sectors: daily labour, services, transportation, wholesale and retail trade. Finally, only half of households have access to credit. When they do, it can place them in a debt 'trap' if they cannot repay the money.

\section{6}

Our economic situation is not very good, and we sometimes borrow money from our relatives to buy food"

19-year-old girl returned from Bulgaria when she was 18

\section{THE UNCRC AND MENTAL HEALTH AND PSYCHOSOCIAL SAFETY}

Article 24 focuses on the broad right to health of children, while Articles $\mathbf{2 5}$ and $\mathbf{3 9}$ specifically mention mental health and the rehabilitation of children who have been neglected, abused or exploited.

Articles 13 and 14 articulate the rights to freedom of expression, thought, conscience and religion, and Article 30 further highlights the rights of minorities in practising their own language, religion and culture.

Article 2 specifies that children should not suffer from discrimination.

Many families originally had more resources, paying migration costs in the tens of thousands of dollars. This money may have been sourced from extended family members - one case study respondent was held in Iran until their grandfather wired $\$ 10,000$ to the smugglers. Returnees return to a financial situation where they are worse off - and with less access to credit - than when they left. A lack of support networks limits employment opportunities. ${ }^{133}$

\footnotetext{
128 Key Informant Interview with the Swedish Migration Agency in February 2018

129 Key Informant Interview with UNICEF Afghanistan in April 2018

130 Afghanistan attack targets Kabul classroom with 600 children inside, Norwegian Refugee Council, March 19, 2018, and Global Initiative on Out-Of-School Children Afghanistan Country Study, UNICEF/UNESCO/Samuel Hall, Foreword, page 9

131 Aid Effectiveness in Afghanistan, 2018, Oxafam and Swedish Comitté for Afghanistan, https://bit.ly/2p/lftb, and https://bit.ly/2OLR4Q0

132 Durable goods here were identified and weighed based on the methodology used for the PIN/DRC Urban Poverty Report. See Urban Poverty Report:A Study of Poverty, Food Insecurity and Resilience in Afghan Cities, 2014, p. 119, for details on the weighing of assets and asset ownership.

133 Past research has highlighted the reliance on informal networks for hiring and employment, posing challenges to returnees' employment opportunities. Designing livelihoods programmes for displaced populations in urban settings in Afghanistan and Pakistan, 2013, for the DaniRefugee Council, p. 44
} 


\section{Mental health and psychosocial safety:A clear call for support}

Upon return, most children interviewed lack access to psychological healthcare, have limited networks beyond the family (and even those may be complicated by return-related tensions), and experience limited inclusion. ${ }^{134}$ They exhibit negative symptoms of psychological wellbeing and inclusion, ranging from rarely participating in social activities to suicide attempts. Past research has highlighted the stigma of return, particularly for deportees. ${ }^{135}$ The contrast between an idealised life in Europe and return to Afghanistan is stark, especially for those who had never been to Afghanistan.

\section{6}

When we arrived to Norway, I was 12, I think. It was like a dream [...] I was very happy to be able to finally breathe and relax after so many years"

19-year-old boy returned from Norway when he was 17

\section{6}

When I was seated in the plane by a policeman I felt very disappointed and while watching the Afghan soil from the plane I was crying. It was really hard to bear. I did not belong to this country and it is the first time I have come here. Everything is difficult in Afghanistan. I am afraid of everything and all people are looking at me in a strange way. I really go backward instead of going ahead. I don't feel comfortable at all"

18-year-old boy returned from

Austria when he was 18

Little support for mental health exists in Afghanistan, although a national mental health strategy has been developed. Limited research on the topic has underlined

\footnotetext{
34 Children returned under IFA or alone just after their 18th birthday in particular may not have familial networks present; older young people whose families sponsored their migration may return to families upset by their lack of 'success' in migration. A recent article detailing the story of Hussain, 27, deported from Finland, detailed his welcome as follows: "When he arrived home, his family didn't know of his deportation and was initially happy to see him. But the mood quickly changed. They now remind him daily of the financial sacrifices they made to get him to Europe." Majidi, N.,"Young Afghans Returning from Europe Face Isolation and Fear back Home"

135 Specifically noting, 'The authors of this report have analysed the stigmatisation that negatively impacts the displaced: the experience of stigma is probably the most difficult social and psychological issue confronting deportees. This research confirms this finding and the vulnerabilities of deportees and internally displaced youth specifically' Urban Displaced Youth in Kabul: Mental Health Also Matters, 2016, Samuel Hall, p. 11; Schuster, L. Majidi, N. "Deportation, Stigma, and Re-Migration”, Journal of Ethnic and Migration Studies, 41 (4), 2015
}

\section{CASE STUDY \\ 12-year-old boy, who was 12 when he returned from Norway}

- 12-year-old boy, who was 12 when he returned

- Country of return: Norway

- Migration history: travelled with his parents and siblings

- Return status: Deported with his family

- Future plans:The family wants to remigrate

I was born in Pakistan. I used to study there. It was $\mathrm{OK}$, mediocre. We then moved to Iran where we stayed for two years. I was not happy in Iran, Iranians would swear at us. We migrated to Europe because of the discrimination: I had trouble going to school, my father did not have legal papers to work, etc

I used to go to school, mainly language classes. I was in class with Norwegian kids, I used to play football with them. In Norway it was clean, beautiful, everything was managed, I was not discriminated against. We were arrested with my mother and my siblings. My father was arrested the next day. They moved us to the deportation centre for one day. The next day at 9am we were deported. They took our phones, we could not call our lawyer.The police said, "Because you were supposed to leave the country and you did not, this is why we are deporting you."

We did not know anyone in Afghanistan except a friend. My main concerns about going to Afghanistan was that I might get killed because there are all these suicide attacks and everything, we were afraid to be at the wrong place at the wrong time. When I arrived, I did not like the weather. The people are strange, the clothing is strange, the schools are not good. Now l'm not going to school because my father cannot offer private schools and for public schools we have to wait until next cycle. The behaviour of the other children here is ok. I did not tell them about the deportation. I am afraid they will think differently about me. I am not happy here. I don't know if we will leave again or not.

We live with the friend of our mother. We only have two rooms for 12 people. At night, we sleep in a tent with my parents and three siblings. My parents were not able to find a job. 
Figure 11: Do you suffer from the following on a regular basis?

Do not know/refuse to answer

None of the above

Difficulty concentrating

Feeling of low self-worth

Feeling lonely

Feeling stressed

Feeling afraid

Feeling sad

Feeling angry
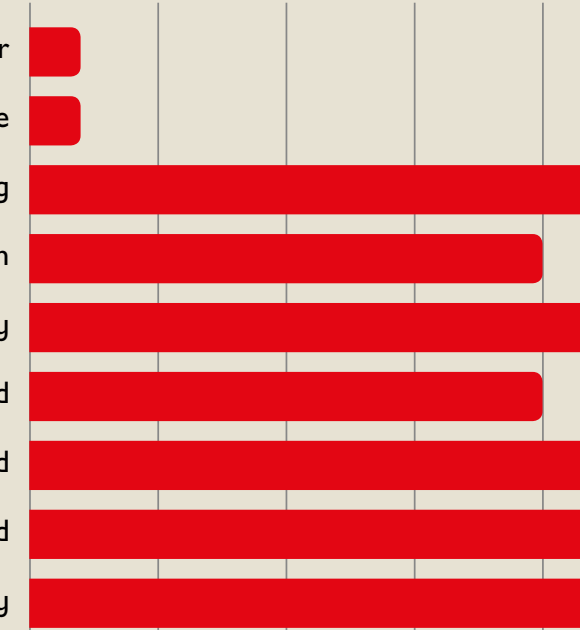

0

5

10

15

20

25

40

45

significant capacity gaps around the provision

of psychosocial healthcare, juxtaposed with high need. ${ }^{136}$ Local NGOs attempt to address this gap, but institutionalised support is lacking. Although NGOs are training counsellors to provide support, the Central Statistics Office noted just 54 psychiatrists in the country in 2016-2017 (46 of whom are in Kabul), while the World Bank finds 'only 320 hospital beds in the public and private sector are available for people suffering from mental health problems. ${ }^{137}$ Furthermore, mental health support is challenged by 'long-held traditions and a culture of stigmatisation of the mentally ill'. ${ }^{138}$

\section{Children's mental health}

Children interviewed exhibit negative symptoms of psychological wellbeing, ranging from fear to anger and sadness (see Figure 11), in addition to recalling traumatic events and incidents linked to their migration. When shown cards representing both positive and negative emotions and asked which represented the emotion felt the most since return, over half - $26-$ selected sadness, and an additional 18 chose worry. The Refugee Support Network (RSN)'s research with young people forcibly returned from the UK to Afghanistan similarly found that 'mental health difficulties and a protracted deterioration in emotional wellbeing are clear and significant outcomes for former unaccompanied minors returned to Afghanistan. ${ }^{139}$
The tendency towards suicide - and consequent need for mental health support on arrival - is thus not an isolated incident. One case study noted a suicide attempt prior to deportation, and five individuals called Save the Children Sweden's helpline to ask about mental health support. One mother in a focus group discussion (FGD) in Sweden noted that her daughter threatened to kill herself if they had to return. Two of the boys interviewed in Norway showed scars from selfharm. One reported,

\section{6}

When I received the first rejection, I lived on the fourth floor. I tried to jump out of the window."

A returnee from Europe and Syria considered the potential for death in Syria as an alternative to suicide. Yet, only seven parents, all of them in Herat, stated that they or their children could access specialised psychological healthcare where they lived, if needed.

\section{Support systems centre on the family}

Parents and children interviewed concur that they do not have people on whom they can rely for support, with only 13 children and three parents or guardians agreeing that they have a network they or the child can rely on for support. The vast majority of networks and people mentioned are at the microsystem level - family and

\footnotetext{
136 Global Health Observatory Data Repository:Afghanistan, 2014,WHO

${ }^{137}$ Afghanistan Statistical Yearbook 2016-2017, 2018, Central Statistics Office,Afghanistan World Health Organisation Situational Update http://www.emro.who.int/afg/programmes/mental-health.html

138 "Afghanistan Tackles Hidden Mental Health Epidemic",2 Sept. 2015, Sune Engel Rasmussen, The Guardian

139 RSN, After return, p. 6
} 
friends. Notably, nine returned children stated having 'no one' in the community who can support them. Returnees need to be better linked and referred to humanitarian governmental support.

Relying on child returnees' abilities to gain support from their families can lead to failure: 'The simple existence of family in Afghanistan does not equate to protection for the returnees. Some young people are not welcomed by family as they have returned from the UK without having met family expectations of their initial migration, while, for others, family resources are too limited for them to provide for a returning young person.140

\section{Limited inclusion and support at the community level}

Interviewed children are split in their feelings of belonging to the community where they live. Both children in Kabul and those returned as unaccompanied children are less likely to feel they belong to the community where they currently live. One explains,

\section{I did not belong there. I did not know anyone}

in Kabul and therefore I was alone most of the time.There was no one to help me with anything when I had a problem. [...] Returning to Kabul after four years without a social network or family is not very easy"

18 year-old boy who was 17 when he was deported from Norway

Child returnees rarely (13) or never (23) participate in social activities within their community, and parents interviewed confirm this (17 of 24 rarely or never participate in such activities). Those who have been returned involuntarily are more likely to report that they never participate in these activities. The importance of these networks is recognised by government agencies returning children to Afghanistan ${ }^{141}$ - yet little is put in place to ensure that returned children can benefit from them.
Figure 12: Do you feel like you belong to the community where you currently live?

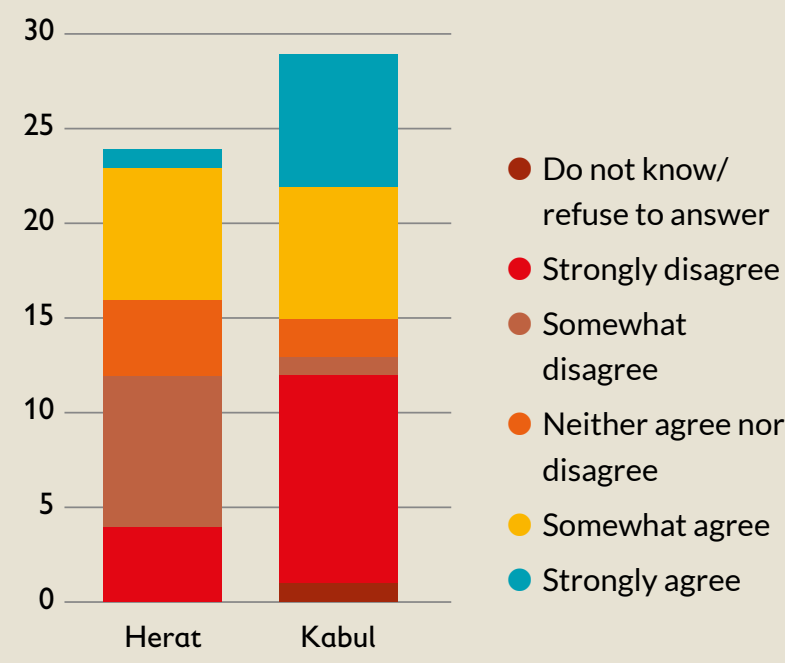

\section{Linguistic inclusion}

All children interviewed report speaking Dari, with ten also speaking Pashto. However, for five children - all involuntarily returned - these are not the languages in which they are most comfortable. Such language barriers can form a great barrier to reintegration and are addressed neither pre nor on return.

\section{Legal safety: Documented but no recourse for action}

Nearly half of children returned to Afghanistan have passports, and they possess tazkera (the primary Afghan personal identification document, which serves as proof of national identity) at rates comparable to that of adult men in Afghanistan more broadly (Figure 13). ${ }^{142}$ However, five children interviewed reported having neither these nor other documents. Although this represents a small portion of the returned children, lacking such documentation means that they cannot enrol in school or access many jobs or higher education. The consequences are severe, and remedies challenging. ${ }^{143}$

\footnotetext{
140 RSN, After return, p. 22

141 Key Informant Interview with the Swedish Migration Agency in February 2018

142 The Norwegian Refugee Council found rates of possession of civil documentation for adult men ranging from $86 \%$ for IDPs/returnees to $94 \%$ for host community members, See Access to Tazkera and other Civil Documentation in Afghanistan, NRC, 8 November 2016, pages 16, 29
} 
Figure 13: Documents possessed by returned children

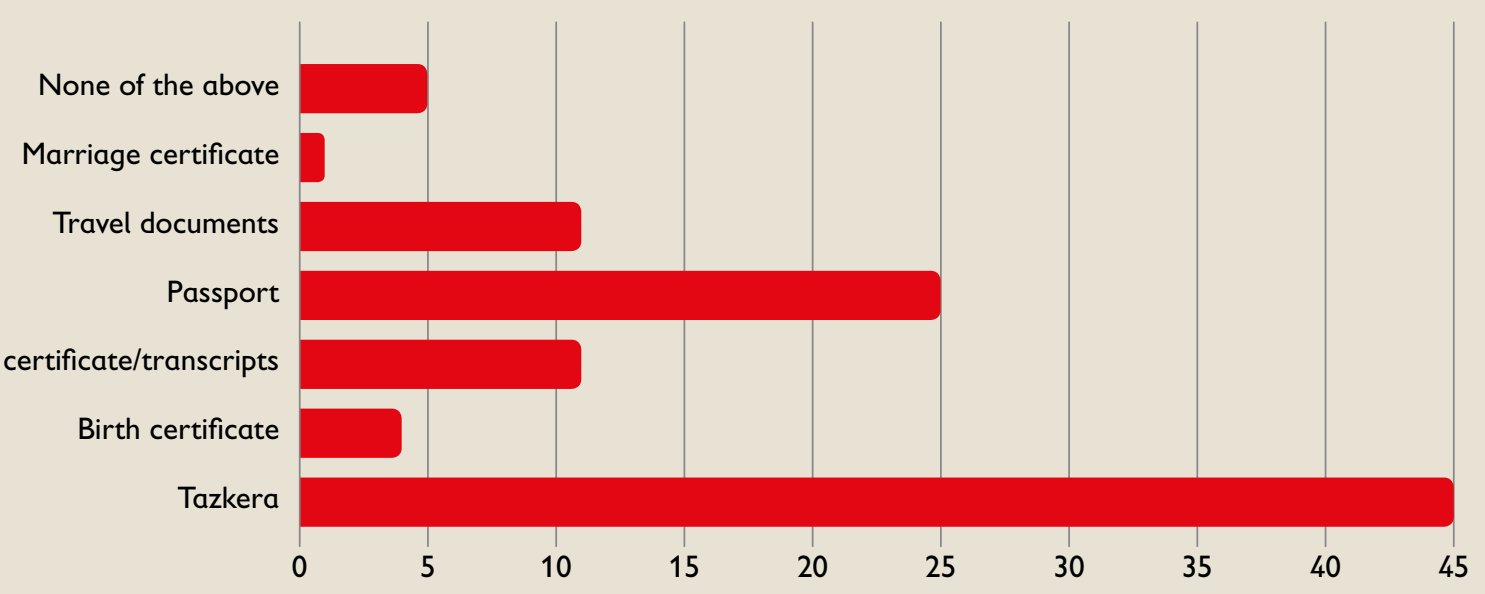

\section{THE UNCRC AND LEGAL SAFETY}

Articles 4, 7, and 8 together detail rights to a legal identity and documentation, for which governments are responsible.

Articles 9 and 10 centre on children's right to be with - or reunited with - their families, excepting in cases where it is bad for them.

Article 12 states that children have the right to freely express their opinion.

\section{6}

I can't enroll at school as I don't have a Tazkera. When I tried to get a Tazkera, I was told I did not belong to this country"

(18-year-old boy returned from Austria when).

Stronger coordination around the return of children needs to occur - and this support should begin before return.

\section{Lack of faith in judicial recourses}

Only a minority of returned children stated that they feel they have a safe access to recourse for justice; 39 saying that they would not go to the police or courts for help if they feel threatened and four others do not know or refused to answer. None of the girls interviewed would consider doing so, although this may demonstrate a broader lack of access to judicial systems for women. ${ }^{144}$

\section{Gender and returns}

Exploring the difference in return for girls and boys was an important part of the research. While, as noted in the research limitations, fewer girls are returning to Afghanistan, ${ }^{145}$ making identifying and interviewing girls challenging, the sections above have highlighted some of the challenges they may face - a difference more broadly confirmed by the children interviewed.

Interviewed children were specifically asked if they had ever felt discriminated against because of their gender. ${ }^{146}$ Both boys (eight out of 46 ) and girls (five out of seven) reported discrimination. Boys also reported discrimination from European governments - perceived as there being less likelihood of girls being returned than boys. The differences between return for girls and boys, often flagged in discussions in Sweden and Norway, was less noted in Afghanistan where only about half

144 A Research Study on the Challenges of IDP Protection in Afghanistan, Samuel Hall/NRC/IDMC, January 2018

145 While no clear gender differential appears within children returning with their families, both other groups considered - unaccompanied minors and children returned at 18 - are almost exclusively male.

146 Intentionally, the interpretation of discrimination was left up to the children interviewed, to allow them to express a breadth of experiences.A later question asked whether there was a difference in return for boys and girls, with an open question allowing these differences to be detailed, to further explain what may have been perceived as discrimination. 
of parents and children interviewed noted differences between return for boys and girls. Among the differences underlined were:

- For girls, a lack of freedom, violence against women, social pressure, and limited ability to protect themselves from harassment. Girls returning to Afghanistan face an additional burden, made heavier by the years they spent in countries where their rights were more respected.

- For boys, pressure to work, being deported more easily than girls, and being less attended to (by foreign governments) than girls.147

Inequality challenges for girls in Afghanistan are huge, with the UNDP indicating that 'women are largely restricted to low-paid, unregulated employment, harassment is widespread, political participation and educational opportunities are limited, and women face numerous obstacles to getting fair treatment from the justice system.' Education is not free from these problems, with primary school participation being of 62.9 per cent for boys but 46.4 per cent for girls, and secondary school participation $\mathbf{4 2 . 8}$ per cent for boys but 21.1 per cent for girls. ${ }^{148}$ Consequentially, Afghanistan is rated $169^{\text {th }}$ on the UNDP Gender Inequality Index. ${ }^{149}$
147 The question of deportation was further detailed by one young returnee as follows in the restitution workshop held in Kabul in August 2018:"The level of boys' deportation is way more than girls. The reason behind this problem is the existing gender discrimination in Afghanistan which influences the European governments as well and they take the decision to deport boys more than girls because they think we can survive in Afghanistan more easily than girls."

148 Afghanistan Statistics Page, UNICEF

149 Human Development Data, UNDP

\section{CASE STUDY}

\section{8-year-old boy, who was 18 when he was deported from Austria}

- 18-year-old boy, who was 18 when he was deported

- Country of return:Austria

- Reason for migration: Domestic violence, forced labour, discrimination

- Migration history:Travelled alone

- Return status: Deported

- Future plans:Wants to re-migrate to Europe

I was very happy and secure in Austria. Everyone treated me like other kids and respected me, I realised what is life and I wanted to live there. I didn't have any problem except the asylum problem.

When I was seated in the plane by a policeman I felt very disappointed and while watching the Afghan soil from the plane I was crying. It was really hard to bear. I did not belong to this country and it is the first time I was going there. My birth place is Iran and I could not even think I would come to Afghanistan.

As I returned to Afghanistan my unfortunate days began. On the same day of my return I was taken to a hotel and 20 minutes later six explosions and an earthquake took place in Kabul. I could not sleep till morning and I heard it will happen again. I was about to die because here in Kabul I had no one. Everything is difficult in Afghanistan.

Everything is quite different here and I can't adjust in this society at all. I can't get enrolled at school because I don't have Tazkera. When I intended to get Tazkera I was told that you don't have a history with us it is why we can't issue you a Tazkera so you don't belong to this country. I have problem even with sleeping in bed, taking bath, shopping all and all and I have no one here to seek help from. Nothing is good here; I have not faced anything good.

People are treating me as a foreigner I am treated badly and people are making fun of me. I don't belong to here and I don't want anything too, I just want to go back. I don't know anyone here. I don't feel safe at all and I don't know whether I will stay alive till the end of this week or not. The main difficulties are with the suicide attacks, I am too afraid.

I currently live in a dormitory with some friends of my friend, who told me I can stay here for 20 days. I am not happy here, there is no electricity, no water and no toilet. I can't buy even a SIM card, so I don't know how to work and earn money. I don't have money apart from the AFG2,500 (N.B. around \$35-40) that I don't know who paid us in the airport. I have a bad toothache and I don't know where to go and how much to pay the doctor. The only dream, ambition and inspiration I have is going out from Afghanistan. 


\subsection{SUPPORT NEEDS AND EXISTING SUPPORT SYSTEMS}

For children in families, support is given at the family level. Unaccompanied children receive the same kind of support as adults, ${ }^{150}$ with the same timelines and duration of follow-up. This points to the lack of child-sensitive counselling and programming both when it comes to preand post-return support. Organisations are reluctant to implement programmes supporting child returnees and unaccompanied children from Europe, possibly because they do not want to generate a precedent where children are returned to unsafe contexts.

Returning children and parents highlight support needs pre-return (Figure 14) and on return (Figure 15). These unmet needs confirm gaps in the implementation of children's rights in return processes ${ }^{151}$ Children are currently being returned to Afghanistan without their protection being assured and without services to afford them the rights accorded in the UNCRC (as detailed previously in this chapter). For states to be able to assess the best interests of children as a group and provide safeguards around their return, and to verify adequate reception for unaccompanied children, including family tracing, there needs to be further communication, cooperation and coordination transnationally. ${ }^{122} \mathrm{To}$ make this feasible, returning countries and organisations should better understand the situation in Afghanistan and coordinate with support available there.

Returns from Europe are lacking a coordinated assistance framework. Existing support is provided at the familial level and depends on the country from which returnees are coming (returnees from Austria, for example, can access both in-kind support and cash grants). ${ }^{153}$ According to key informants, European governments are not coordinating in advance with the Afghan government on the return of children. More broadly, child-specific support for these returnees is missing. Existing programming that could provide support is not coordinated with returns from Europe.

\section{Support needs pre-return}

Support needs specific to children were flagged by 19 respondents. Most child returnees lack access to the education system, while re-adaptation and language classes are recognised as being key to their mental health. Through migration, most of the children interviewed had lost critical years of their education - on average three years: two years during their journey to and in Europe, and one year upon return. This creates a gap between age and enrolment that leaves many unprepared to re-enrol once they obtain necessary documentation and know how to do so. To avoid returnee children falling out of the school system, and ensure that these children have the necessary tools and skills to succeed in the Afghan educational system, re-adaption and language classes are necessary. ${ }^{154}$

Children worry more than their parents about the lack of healthcare and community support (see Table 4 below), and that their own network stops with their family ${ }^{155}$ They do not know who to reach out to outside of their homes, they have not socialised in their new environment and they cannot rely on having phones or means of communication with others. Their psychosocial health and physical needs rank much higher than that of their parents and guardians.

\section{Support mechanisms and stakeholders}

Existing support to child returnees in Afghanistan is fragmented and inconsistent. There are no guidelines or dedicated support to integrate them as part of other child-specific interventions. A mapping of actors at national and local levels and a structured network of civil society organisations could strengthen support for returning children.

\footnotetext{
150 In some countries such as Norway unaccompanied children might recive a higher cash grant that adults

151 See Chapter 3.

152 The EU Returns Directive in Art. 10 specifically notes that for the return unaccompanied minors, "Before removing an unaccompanied minor from the territory of a Member State, the authorities of that Member State shall be satisfied that he or she will be returned to a member of his or her family, a nominated guardian or adequate reception facilities in the State of return."

153 Key Informant Interview,ACE, Kabul, March 2018

154 Children studying abroad may have been following a different curriculum and studying in a different language. Children not studying abroad may have fallen behind their age group. Preparation prior to return to reintegrate the schooling system can reduce some of the factors likely to lead them to drop out.

155 While the sample size is low, 24/53 (45\%) of children listed community support as a need on return, versus 33 per cent of parents interviewed.
} 
Figure 14: Pre-return priority support needs*

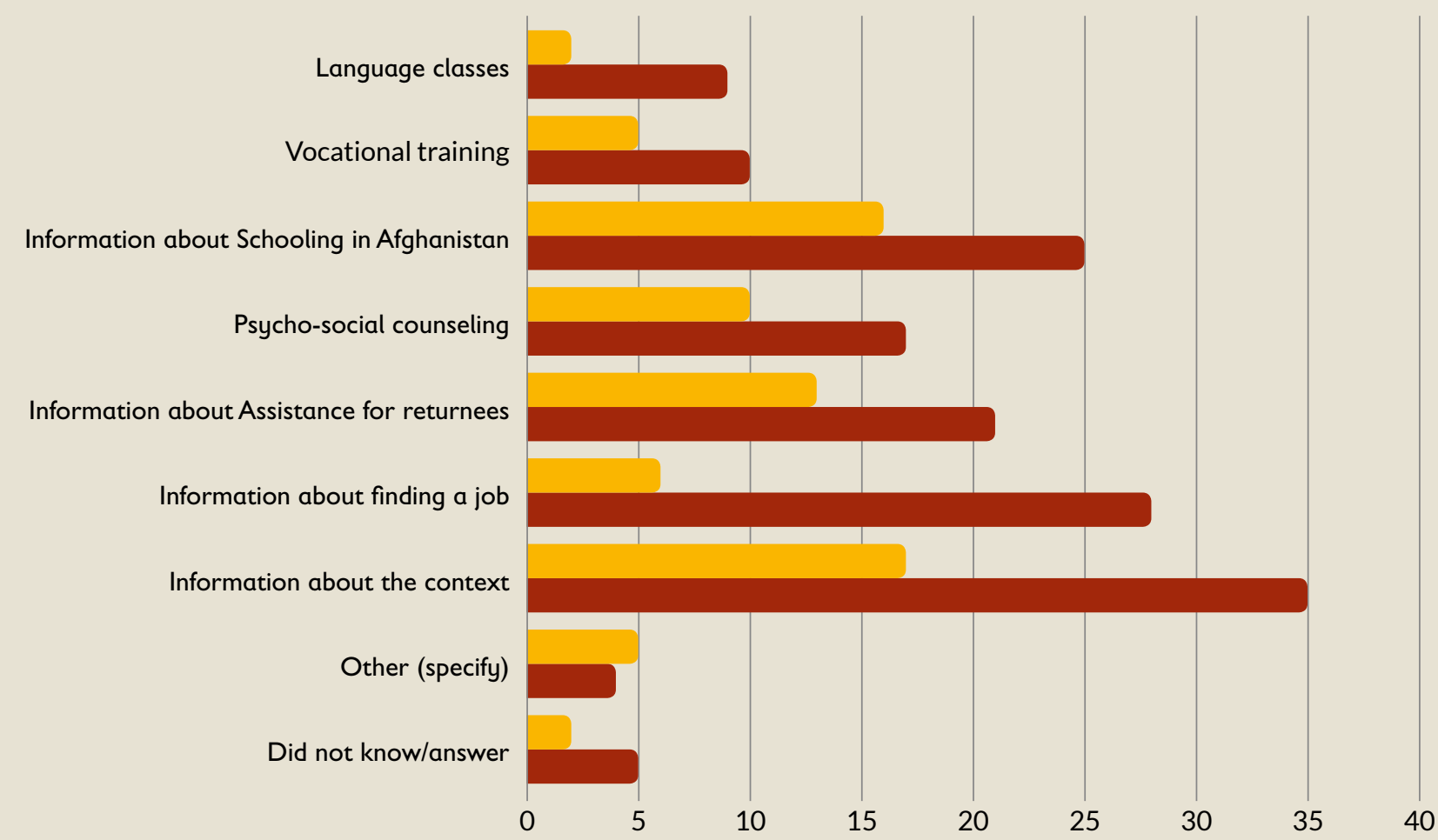

What support do children require before returning to Afghanistan? (parents/guardians interviewed)

What support do children require before returning to Afghanistan? (children interviewed)

* Other includes financial support, security, and basic needs (accommodation, food).

Figure 15: Organisations currently and potentially working with children returned from Europe
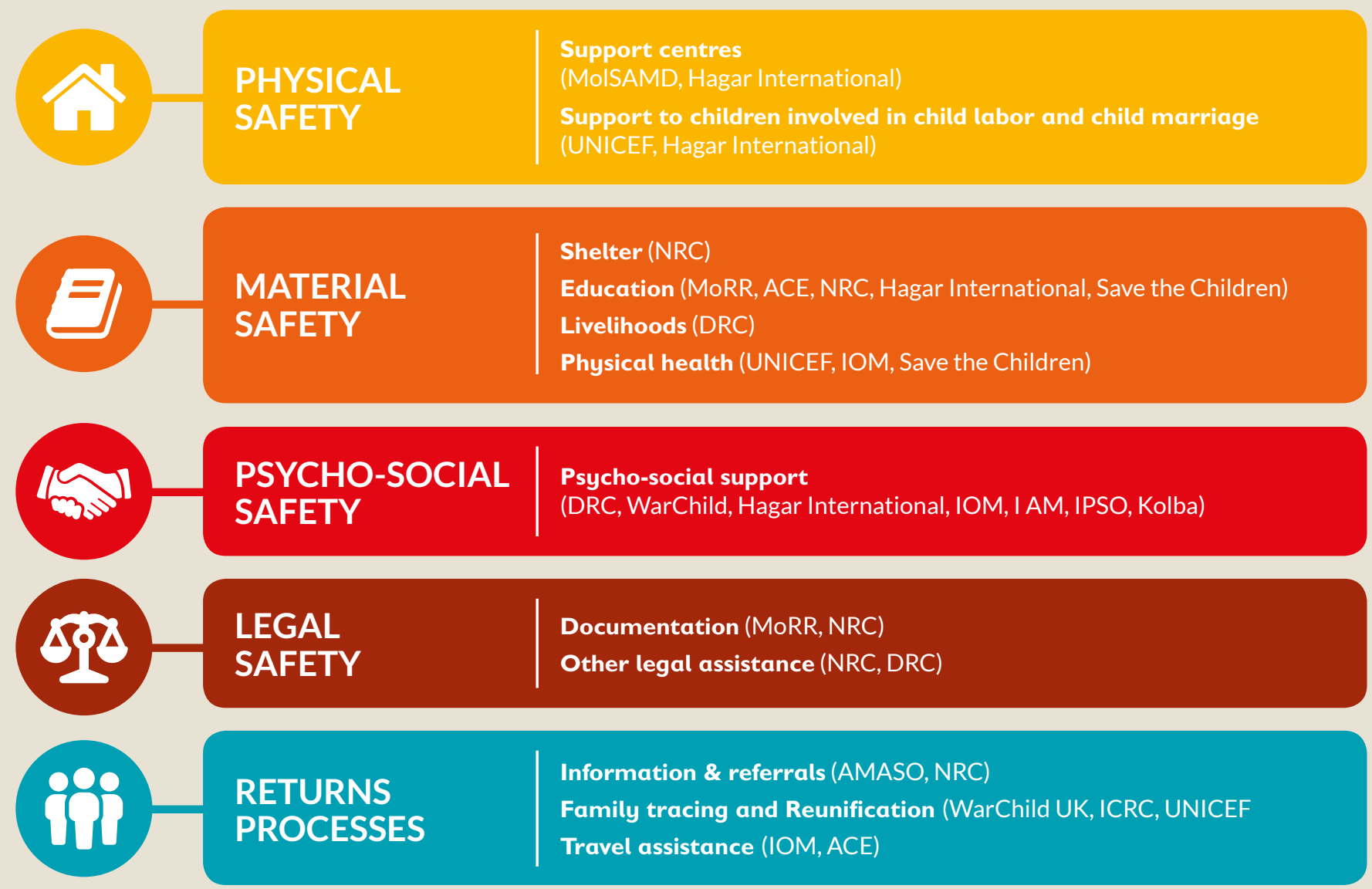
Table 4: Key needs on return to Afghanistan, parents and children interviewed

\begin{tabular}{|c|c|c|c|}
\hline $\begin{array}{l}\text { Durable } \\
\text { solution } \\
\text { dimension }\end{array}$ & Greatest needs & $\begin{array}{l}\text { What do you think are } \\
\text { the greatest needs for } \\
\text { children once they return to } \\
\text { Afghanistan? } \\
\text { (Children) }\end{array}$ & $\begin{array}{l}\text { What do you think are } \\
\text { the greatest needs for } \\
\text { children once they return to } \\
\text { Afghanistan? } \\
\text { (Parents/guardians) }\end{array}$ \\
\hline \multirow[t]{3}{*}{ Physical } & Health support (psychosocial/physical) & $34(17 / 17)$ & $14(8 / 6)$ \\
\hline & Community support & 24 & 8 \\
\hline & Social network & 3 & 3 \\
\hline \multirow[t]{2}{*}{ Material } & Financial support & 41 & 15 \\
\hline & Support specific to children & 14 & 5 \\
\hline \multirow{3}{*}{$\begin{array}{l}\text { Psychosocial } \\
\text { and mental } \\
\text { health }\end{array}$} & Access to the education system & 43 & 17 \\
\hline & Re-adaptation classes & 13 & 4 \\
\hline & Language classes for returnees & 9 & 5 \\
\hline \multirow[t]{4}{*}{ Legal } & Documentation & 23 & 13 \\
\hline & Family reunification & 14 & 1 \\
\hline & Access to a lawyer & 7 & 2 \\
\hline & Legal advice & 4 & 1 \\
\hline \multirow[t]{2}{*}{ Other } & Do not know/answer & 2 & 13 \\
\hline & Other (specify) & 1 & 2 \\
\hline
\end{tabular}

The lack of a clear policy framework on child returnees in Afghanistan and the lack of verification around implementation of safeguards are critical gaps that prevent coordination and administration of responsibilities:

- Existing child rights safeguards are not fully implemented, as seen in the section on returns processes.

- Children are returning to an environment that does not afford them access to rights guaranteed in the UNCRC.

- Based on interviews with European government agencies, legal responsibility by returning countries ends when children land in Kabul. Benefits provided to voluntary returnees (such as in-kind support) are often given at the family level, not necessarily benefiting children, and their type and scope depends on the returning country (returnees from Austria, for example, can access both in-kind support and cash grants).

Figure 15 shows organisations currently and/or with the potential to work with children from Europe. At the time of writing, the organisations involved do not have adapted structures to support child returnees specifically. This may in part be because organisations do not feel comfortable supporting the return of children to a precarious context such as Afghanistan, as this could create a precedent for returning more children to other unsafe situations. Support occurs on a case-by-case basis with no standardised procedure or clear point of contact at the Afghan ministries. Additional support could be provided by organisations working with returnees from other countries such as Pakistan and Iran if clear referral mechanisms existed. Many of the organisations interviewed noted that they have no way of identifying child returnees from Europe, and that these are not being referred to them.

If reintegration as a process is to succeed, the gaps between economic (encouraged by current 'packagebased' support provided at the familial level) and social reintegration must be bridged.

\section{Limited support, challenged reintegration}

Existing support for children returning from Europe is limited and fragmented. The full potential of existing programming is not targeted specifically at these groups or is underutilised. This lack of support places a further barrier on the realisation of returnee children's rights as detailed in the UNCRC. ${ }^{156}$ The IASC Framework notes that 'the needs, rights and legitimate interests of IDPs should

156 The earlier sections of this chapter flag articles making proviso for rights which the research shows are not respected for returning children. 
be the primary considerations guiding all policies and decisions on durable solutions. ${ }^{157}$ This chapter highlights that both the needs and rights of returnee children from Europe, as voiced by the children themselves and accorded by the UNCRC, are currently not being met. While the problems evidenced are not all specific to returned children and also reflect challenges faced by children and adults in Afghanistan overall, with only ten children saying they are not planning to re-migrate the processes and support necessary to ensure sustainable returns for children are clearly not in place.

\section{WHAT CHILDREN WANT}

Children in the research specifically asked for the following support to be provided by returning countries:

- Information about Afghanistan, how to find a job, access to education and return support

- Psychosocial support and counselling

- Vocational training

- Language courses

- Help in transferring and translating grades

Children also prioritised the support they need in Afghanistan:

- Access to good-quality education

- Financial support

- Access to healthcare and psychosocial support

- Access to community support and social networks

- Help with documentation

- Family reunification

- Re-adaptation classes

- Language classes for returnees

- Access to a lawyer and legal advice

\section{CASE STUDY}

18-year-old boy, who was 17 when he was deported from Norway

- 18-year-old boy, who was 17 when he was deported

- Country of return: Norway

- Reason for migration:Threats against him after the Taliban killed his father

- Migration history:Travelled alone

- Return status: Returned voluntarily with his family

- Future plans:Wants to travel to Europe

I applied for asylum in Norway.After 5 months, I was interviewed, but they were confused about whether I was a minor. They did age assessment, I was sure I was a minor so I had no problem. Different people had different opinions, some said I was 15-16, some said 18. I got first negative after five to six months. I appealed and many of my teachers and the doctor wrote letter to the Immigration Department to accept me as a minor, but it didn't help. The lawyer they provided me with didn't help me at all. They took me to the deportation centre where I stayed for a month and then I was deported back to Kabul. I wasn't ready, and nobody had told me anything about the situation in the country. Security was the biggest concern for me and I was afraid that I will get killed if I return. I used to hear about the bomb blasts and suicide attacks and that was on my mind at all time during and after return to Afghanistan. It is kind of the same for both boys and girls to return. If there is a bomb in the city there is not difference either you are a boy or a girl, you both can be a victim. The Taliban mostly takes the boys, so for boys it can be more dangerous, but girls also have their own problems.

When I was deported, it was the first time I was setting foot in Kabul. They were telling us to go and live in Kabul because Kabul was safe to return to. There were also two journalists who were following up the return of boys from Norway and interviewed us. I didn't go to school in Kabul. I didn't belong there. I didn't know anyone in Kabul and therefore I was alone most of the time. There was no one to help me with anything when I had a problem. Social network would have made life a little easier for me. Returning to Kabul after four years without a social network or family is not very easy. I used to get mad and upset living alone without any support. No one should be deported to Afghanistan, especially children. If they are deported, they should be provided with support for school, accommodation and health services. None of them exist for the child returnees now.

I returned in January 2018, and in May 2018 I went to Turkey; I'm currently living there. Here I feel safe from bomb blast and suicide attacks. But still I have a fear, the fear of being arrested by Turkish police and deported back to Afghanistan. I work in a factory here, they pay us, provide accommodation and lunch. 


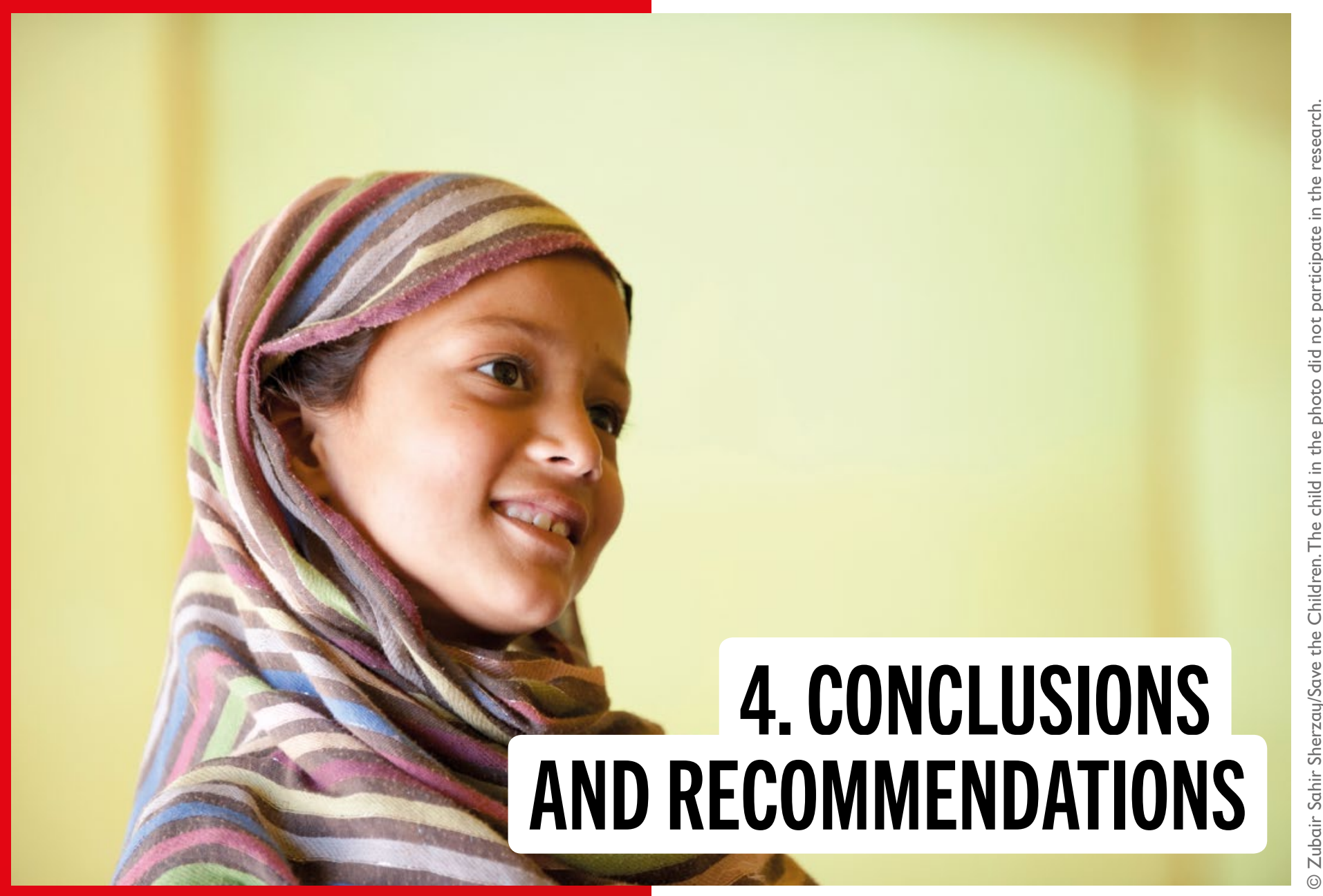

\subsection{CONCLUSIONS}

This research presents the experiences of children returning to Afghanistan from Europe. The stories of these children - unaccompanied, with families, or recently turned 18 who returned both voluntarily, through voluntary departure, and involuntarily - reveal concerning gaps in the implementation of safeguards in children's returns and, more broadly, call into question the appropriateness of such returns to Afghanistan.

The Afghan security context, even in zones deemed safe for internal flight alternatives by returning governments, is worsening. UNHCR stated in its recent eligibility guidelines that 'given the current security, human rights and humanitarian situation in Kabul, the internal flight and relocation alternative is generally not available'. 158 In the first quarter of 2018 alone, there were 2,258 civilian deaths in Kabul. ${ }^{159}$ In addition to general security concerns, education facilities are increasingly targeted

158 UNHCR, Eligibility Guidelines forAssessing the International Protection Needs of Asylum-seekers from Afghanistan, 2018, http://www.refworld.org/pdfid/5b8900109. $p d f$

159 UN Officials, as reported in "Civilian casualties in Afghanistan at nearrecord level this year, according to UN report" 13 April 2018, Pamela Constable in The Washington Post 
by armed groups. ${ }^{160}$ Furthermore, the case studies in Afghanistan - as well as the discussions with children in Sweden and Norway - reveal that stigmatisation due to perceived 'westernisation' is a very real fear. While having spent time abroad does not always imply a risk of specific targeting, the risks faced by returning children are worsened by the fact that, in some cases, the threats that led families and individuals to go abroad, such as targeting by insurgent groups or fear of kidnapping, remain upon return.

Children return to an environment where their rights accorded by the UNCRC cannot be fully realised, and conditions defy requirements for return. Limited cross-border cooperation and lack of monitoring at different levels further complicate the application of safeguards. Representatives of several migration agencies and embassies interviewed could not identify children returned to Afghanistan. To our knowledge, no monitoring at individual or structural level post return is currently taking place.

Families and unaccompanied children migrating to Europe are sometimes seen as better off financially than other populations in Afghanistan and therefore not in need of support. Even if this were true, they are not necessarily better off after return. On the contrary, the lack of networks, for example, can make it difficult to find livelihood opportunities. It appears that returnees from Europe are not accessing existing services and support.

Durable solutions require that a child is able to develop into adulthood in an environment that will meet his or her needs as well as fulfil her/his rights as defined by the UNCRC and that will not put the child at risk of persecution or harm. ${ }^{161}$ The research shows that the environment to which children are being returned in Afghanistan is not conducive to such development. Migration management approaches driven by political developments in Europe appear to be driving returns decisions rather than an assessment of the appropariateness of returning children to Afghanistan.
Children returning to Afghanistan face difficulties in accessing reliable shelter, education, jobs and medical support, and risk recruitment to armed groups and physical harm due to conflict. Child returnees face psychosocial and in some cases legal challenges, which render reintegration improbable and pose fundamental challenges to their wellbeing. Currently, returns to Afghanistan cannot be considered durable.

\subsection{RECOMMENDATIONS}

The recommendations are designed to support stakeholders in Afghanistan and in Europe in ensuring that children seeking asylum have access to sustainable solutions that are in their best interests, as required by the UN Convention on the Rights of the Child. It is evident that children's rights need to be strengthened and placed higher on the migration agendas, especially regarding return and reintegration practices.

The main point of departure for these recommendations is the UN Convention on the Rights of the Child and the authoritative guidance provided by the Committee on the Rights of the Child on States Parties' obligations through its various General Comments. ${ }^{162}$ Article 3 in the Convention, which obliges states to consider the best interests of the child in all decisions concerning a child, has been the overarching guiding principle of this study and the recommendations. Additionally, children have the right to be heard and to express their opinions, in all matters concerning them, and therefore their experiences and suggestions provided the backbone of the recommendations on how to realise the rights of children in a returns context; in this case, returning children from Europe to Afghanistan. It is our hope that these recommendations can also be used to ensure safe returns and durable solutions for all children concerned.

\footnotetext{
160 See for instnce NRC article: https:/www.nrc.no/news/2018/august/cut-the-throats-of-three-school-employees/

161 Safe \& Sound, UNHCR/UNICEF, 2014, Save the Children expands this definition to include all children, including children in families.

162 CRC General Comment No 6 (2005): Treatment of unaccompanied and separated children outside their country of origin, CRC General Comment No 14 (2013) on on the right of the child to have his or her best interests taken as a primary consideration (art. 3, para. 1)*Joint general comment No. 3 (2017) of the Committee on the Protection of the Rights of All Migrant Workers and Members of Their Families and No. 22 (2017) of the Committee on the Rights of the Child on the general principles regarding the human rights of children in the context of international migration*, Joint general comment No. 4 (2017) of the Committee on the Protection of the Rights of All Migrant Workers and Members of Their Families and No. 23 (2017) of the Committee on the Rights of the Child on State obligations regarding the human rights of children in the context of international migration in countries of origin, transit, destination and return*
} 


\subsection{OVERARCHING RECOMMENDATIONS}

(1)

\author{
EU Member States and Norway should \\ immediately stop returns of children to \\ Afghanistan.
}

Findings such as attempted recruitment, a lack of network, family and reintegration plans combined with the volatile security situation in Afghanistan, show that returning children, both unaccompanied and with their families, cannot be considered to be in their best interests.

We therefore recommend that returns of children to Afghanistan are halted immediately and not resumed until significant lasting changes can be seen and thoroughly documented, ensuring effective protection of returnee children. Our research shows that very few returns from Europe are motivated by a genuine wish to go home, but rather by the fact that no other options are available. Therefore, governments cannot justify returns by labelling them as voluntary. These returns do not happen with the child as a key agent.

2

\section{EU Member States and Norway should fully} and consistently apply internationally accepted standards on best interests procedures.

To ensure that returns to any country of origin are sustainable and child-sensitive, formalised multidisciplinary best interests procedures should precede the identification of a durable solution for a child, duly taking into account the child's views. Improved best interests procedures should include a detailed outline of how best interests assessments are carried out and which necessary safeguards should be implemented. These obligations refer to all asylum-seeking children and not specifically to children from Afghanistan. Returns should only take place when in the best interests of the child. Children who started the procedure before turning 18 should continue to be treated as children, and their cases should be dealt with urgently by the states to ensure that they have access to a sustainable solution before they reach the age of majority.
(3)

EU and Member States to support migration and returns agencies in the development of robust child safeguarding and child protection policies.

To ensure that children feel safe during returns procedures, migration and returns agencies should develop and apply child safeguarding and child protection standards during returns procedures. These should include training of staff accompanying children in returns procedures, having a child protection and child safeguarding focal point during returns operations, and ensuring that families stay together during returns operations.

(4)

EU Member States, Norway and the Government of Afghanistan should ensure that all children receive child-specific support and individual reintegration plans.

While some attention is given to pre-return preparations, there is little to no investment in the reintegration of children and families after return. Governments responsible for returns need to establish proper reintegration processes. Generally, individualised reintegration plans can facilitate sustainable and childfriendly returns. These plans should include mechanisms for post-return monitoring, coordinated between returning Member States and agencies, the country of origin, and local child protection actors.

5

The Government of Afghanistan should include children returned from Europe in policies addressing child protection and child returnees.

The Afghan national child protection legislative and operational framework offers opportunities to integrate returned children. A policy framework for returnees and IDPs exists, but there are no specific directives for child returnees. The domestic law needs to fully integrate the UNCRC, and the Child Act needs to be urgently finalised in order to strengthen national and local child protection systems. Such laws should include returned children and their hosting communities. 


\subsection{RECOMMENDATIONS TO EU MEMBER STATES AND NORWAY}

(1)

EU Member States and Norway should ensure that children receive age appropriate and specific support before, during and after return.

Children who participated in this research identified specific needs to facilitate their returns procedure. These include:

- Information about the general context in Afghanistan, access to education, and livelihoods opportunities

- Psychosocial support and counselling to provide information and prepare for a potential return. This information should then translate into a clear reintegration plan and a continuum of support coordinated by returning states prior, during and post return.

2

EU Member States and Norway should improve the monitoring of returns at different levels.

- Monitoring at the individual level needs to include follow-up of both children in families and unaccompanied children and should continue at least three months after return.

- At a structural level, idependent institutions and organisations should carry out monitoring of return and reintegration procedures. The monitoring could look at conditions for returns, with the help of, for example, Save the Children's Childs Sensitive Durable Solutions Framework and through interviews with children who have been returned to different countries of origin.

3

\section{EU Member States and Norway should establish} a formalised and mandatory procedure to assess the best interests of the child prior to identifying a durable solution, which should:

- Include children's rights and specific vulnerabilities should be included as well as the views of the child.

- Ensure that robust family tracing procedures are in place. A family assessment by qualified actors should be included to determine whether return to her or his family is in the child's best interests.

- Be carried out by child protection actors, who are trained to engage with children

- Take a multidisciplinary approach and include cooperation between all relevant actors

- Include the provision of child-friendly information and counselling
- Ensure that decisions are taken by a multi-agency panel, including child protection expertise

- Ensure that the best interests of the child are a primary consideration when determining the status of the child.

4

Procedures related to voluntary returns - eg when a child or a family withdraws an application should include the same safeguards as other types of return.

- In the case of unaccompanied children, a home assessment should always be carried out prior to return to ensure that the child's family is willing and able to accept the child back. If family cannot be traced and assessed, alternative care arrangements should be made in the country where the child has applied for asylum. Current facilities and institutions are not adequate for the reception of unaccompanied children returning to Afghanistan.

- In the case of children in families, more guidance is necessary. States should consider implementing a best interests assessment to determine whether return could put the child at risk.

5

EU Member States and Norway should ensure that unaccompanied children are not left waiting in limbo with an unresolved status until they turn 18.

- A best interests assessment requires decision makers to consider the long-term effects that a decision or action may have on a child's welfare and development, including those effects that will be felt after the child has reached his/her $18^{\text {th }}$ birthday. States should also shorten the time it takes to process asylum claims, without jeopardising the rights of the child. Unaccompanied children should be prioritised. Temporary protection until the child has reached the age of majority cannot be considered a sustainable solution.

6

\section{EU Member States and Norway should take} preventative measures to ensure that children are not subject to violence or coercion in returns procedures.

- States should limit the involvement of police and law enforcement actors in the return of children and ensure that there are guidelines in place. The detention of children for migration control purposes should be unlawful. 


\subsection{RECOMMENDATIONS TO THE EU AND ITS INSTITUTIONS}

(1)

The EU should invest in child-sensitive durable solutions, including access to good-quality education, healthcare and the strengthening of child protection systems.

Although returned children have specific needs, children in Afghanistan generally face many of the concerns highlighted in this research. Rather than making development spending contingent on cooperation in the field of migration management, more investment should be made in strengthening education, healthcare and child protection systems. The New Multi-Annual Financial Framework of the European Union will include significant investments in 'migration management' through instruments such as the Asylum and Migration Fund and the Integrated Border Management Fund. These should prioritise investments in child-sensitive solutions.

The Asylum and Migration Fund can support pilots to establish multidisciplinary panels to assess the best interests of the child in specific Member States. It can also invest in pre-return support for children, including counselling and measures to support integration if return is not found to be in the best interests of the child.

\section{2}

The EU - including the European Parliament, the European Commission and EU institutions should integrate guidance on how to implement best interests of the child procedures in existing legislation and policy.

All actors should work towards integrating concrete measures and safeguards related to children's rights and best interests procedures into existing, recast and new legislation and policies. This includes the currently recast returns directive, the return handbook, and legislation that is currently under negotiation such as the European Border and Coast Guard Regulation, the Asylum Procedures Regulation and the Qualifications Regulation.Various EU agencies and institutions are responsible for asylum and returns procedures, including identifying durable solutions for children. We encourage the European Migration Network, Directorate- General for Migration and Home Affairs, the European Border and Coast Guard Agency and the European Union Asylum Agency, among others, to work together to develop practical guidance on the implementation of best interests procedures in asylum- and durable solutions processes.
(3)

The European Commission and its institutions should promote coordination with countries of origin and increased monitoring of returns involving children and families.

The European Commission should lead efforts ensuring better coordination between Member States and with authorities in countries of origin, including on childspecific procedures and safeguards. The EU can support several steps to ensure better coordination, such as:

- $\quad$ supporting post-returns monitoring, and broadening the monitoring called for in the Returns Directive to facilitate this

- ensuring that agencies and institutions involved in returns procedures support a harmonisation of reintegration packages and include child-specific components focused on sustainable reintegration of children and their families

- supporting the establishment of a coordination body bringing together focal points from different Member States, operating in both the returning Member State and Afghanistan, the responsible Afghan authorities, and organisations and agencies working with returnees. This would ensure alignment of the returns procedure and existing safeguards, proper monitoring upon return, and the establishment of sustainable, child-sensitive reintegration plans.

\subsection{RECOMMENDATIONS TO THE GOVERNMENT OF THE ISLAMIC REPUBLIC OF AFGHANISTAN (GOIRA)}

(1)

The GolRA should integrate child returnees and policies addressing child returnees into the national child protection framework.

We welcome the steps the Government of Afghanistan has taken to ensure that children are protected by signing and ratifying the UNCRC.We encourage the government to ensure that child returnees are protected by creating necessary legal safeguards. 


\section{CASE STUDY \\ 19-year-old boy, who was 17 when he was deported from Norway}

- Returnee: 19-year-old boy, who was 17 when he was deported

- Country of return: Norway

- Reason for migration:Threats against the family, discrimination in Iran

- Migration history: travelled with his parents and siblings

- Return status: Deported with his family

- Future plans:Wants to re-migrate to Europe legally, through scholarship

My sister was separated from us in Turkey, forced by the smugglers. After one-and a-half, two years, we found out that she is in Norway. During this time, we were in Greece, we had to sleep in parks, it was a difficult life there. From Greece we received an invitation from my sister for family reunification in Norway, after she got asylum. When we arrived to Norway I was 12 I think.

The day of my brother's birthday, my sister came to celebrate. Around midnight, around 15 police officers came and surrounded the house. They told us we had to pack our things and go back to Afghanistan. We were all shocked, we were crying. We were not conscious of acts and behaviors. My sister stayed in Norway. We were sent to a prison next to airport. I was separated from my family because I did some crazy things. No one explained to me what was going on. We did not receive any kind of help or information. We were just taken to Afghanistan. They were 11-12 police officers who came with us to Kabul. I was just so depressed I could not think. The day before we were deported I tried to take my life.

Before returning, I was thinking about Afghanistan with bomb blasts, people killed for no reason, civilian victims of terrorist attacks, a lot of religious pressure, a lot of issues, only negative things that could go to my mind every time I would think about it. We had no one to help us in Kabul.We moved several times, maybe seven or eight times, and we are still moving every 5-6 months. It's because we do not feel safe, because of our security.

Since returning, all my family, we are all trying not to draw attention from people. At school I told the other students I returned from Iran. Outside, I don't talk Norwegian, for example when I'm with my brother, even though we're more fluent in Norwegian than in Dari. We are very careful with our language, attitude, behaviour. We had to lie; I lied to my classmates.

I don't belong in my community. I don't belong here. I wish I was born in another country. I don't want to migrate illegally again, but I want to go to another country through scholarship. I don't know where, just out of this country. We might go to Iran of the situation gets worse than this. I'm trying my best to get out of this country as soon as possible. I'm going to apply for scholarships after TOEFL test. 
(2)

\section{The GoIRA should establish a clear policy framework with responsibilities to governmental ministries concerned with child returnees.}

- In particular, the Ministry of Labour, Social Affairs, Martyrs and the Disabled (MoLSAMD) through its Child Protection Secretariat, and the Ministry of Refugees and Repatriations (MoRR) through its own mandate around returnees, should provide the GolRA with a stronger position in discussions around child returns. The Child Protection Secretariat at MoLSAMD is well-placed to lead this policy initiative to ensure that children's rights are realised. One actor, MoLSAMD, should be the main responsible actor in terms of coordinating with different agencies and authorities, as well as with child protection actors in Europe.

(3)

The GoiRA should fully integrate the UNCRC into Afghan law through the Child Act.

- This will give the child protection system more weight. Additionally, it will give the UN and international NGOs further grounds to support the GoIRA in ensuring children are not returned to Afghanistan when it is not in their best interests.

\section{4}

The GoiRA should support the establishment of coordination and referral mechanisms enabling better reintegration of returned children. It should:

- Develop - in cooperation with returning countries, agencies and child protection organisations - an action plan to support reintegration. Existing services and arrangements could be mapped, and a coordination body could look into specific pre- and post-return support systems. This should include establishing links between the returning child and support services in the country of return, awareness raising and pre-counselling on the situation in the country of return, and clear referral mechanisms in the country of return. Specific 'one-stop shops' for referral should provide guidance on which services are available to returning children and families, including (psychosocial) healthcare and access to education

- Create an effective identification and referrals mechanism for child returnees (not specific to those coming from Europe)

- Implement appropriate support mechanisms, such as: the provision of documentation to children as soon as they arrive, the sensitisation of returning children to risks faced in Afghanistan (eg recruitment to armed groups), and referrals to organisations providing support.

\subsection{RECOMMENDATIONS TO ALL STAKEHOLDERS PROVIDING SERVICES TO CHILD RETURNEES IN AFGHANISTAN}

\section{(1) \\ Actors should support the strengthening of child protection systems in local communities.}

Save the Children has been working in Afghanistan to strengthen the child protection system at the local level; such initiatives can be strengthened and scaled up.

Community and familial support are essential in reintegration processes in Afghanistan. Returned children may be stigmatised or perceived to have failed as they have not brought a 'return on investment' for those who paid to send them abroad. NGOs and CSOs are best placed to work within communities to address this.

(2)

Actors should coordinate existing activities around returns to support child returnees from Europe and their families.

Child returnees from Europe should receive adequate supportand as far as is possible be integrated into existing support mechanisms for returning children. This in turn must be better coordinated to avoid duplication of efforts or major gaps in support areas. The following actions could be considered for all children regardless of their place of departure:

- Map existing support services for returnees in order to permit referrals, including a network analysis to identify which actor is best placed to provide psychosocial support.

- Link returning returnees to this referrals mechanism. The cross-border nature of organisations can support this.When a child in Europe is identified as soon to return to Afghanistan, European service providers should link up with the Afghan service provider to more effectively answer questions and prepare for return. This can also include linking returnees to each other -while still in Europe or on return - to enable them to create their own support networks. 


\section{CASE STUDY}

\section{6-year-old girl, who was 13 when she returned from Norway}

- 16-year--old girl, who was 13 when she returned

- Country of return: Norway

- Reason for migration:Threats against the family, insecurity

- Migration history:Travelled with his parents and siblings

- Return status: Deported with her family

- Future plans:Wants to continue her education and maybe return to Europe through scholarship

I was born in Kabul. I was nine when we left Kabul. My father had issues and enemies, this is why we left. We left with my parents, three brothers, and one sister. It was very long and difficult, very difficult. I remember that 3,4 men died on the way. We were forced to stay hungry for many days, that was our biggest issue.

We applied for asylum. My sister and I were also interviewed as part of this process, separately. We got the first rejection and appealed. We got the second rejection but not the letter saying that we had to leave the country. I was 13 at that time. One day, on the morning, the police came. We did not expect that. They took us to the deportation centre for 19 days

In the plane we were accompanied by policemen. My brother, around 15, was handcuffed. The police treated us respectfully. No one welcomed us at the airport. Someone just sent us to a centre of the ministry. In my mind, I wasn't excited to return, we used to watch the news, see the bombs, the explosions. We were also traumatised because we did not know where our brother was. When we returned, we did not have any family or friends to help us. My main concerns before returning were security and freedom; we had much more freedom in Norway, [and] I was concerned about what would happen to my freedom in Afghanistan.

Now I go to school, my biggest problem is that the school is too far, it takes at least one hour to go to school. We are sitting in the class, but all the minds are on the door, because our school is under threat, because it's a girls' school. Other than that, I like the school. No one knows than I returned from Europe, I don't tell anyone.

Returning was different for me and my sister and for my brothers: for girls is much more difficult, you don't have the freedom of yourself, the freedom of yourself, when you leave the house you face a lot of harassment. I don't feel safe at all here. I face a lot of harassment. The best thing that happened is that we are still alive.

I want to continue my education, have freedom, have security. If I can, I want to work on the security situation in the country, make it more livable. I don't want to go back to Europe; I'm tired. I didn't have a good experience during the journey: we were too close to losing our lives, [and] we saw a lot of danger. Of course, if I can have scholarship it's different. We faced a lot of issues, but at the end we also had a bad experience. 


\subsection{RECOMMENDATIONS TO THE UN AND UN INSTITUTIONS}

(1)

\section{The UN should strengthen UN-coordinated approaches and responses on safe and dignified return and reintegration.}

This can be done through coordinating child rights-based and child-sensitive policies, guidance and frameworks and by supporting the implementation of the Global Compact for Migration provisions relevant to children's best interests determinations, returns and reintegration.

- While there is an EU legal and policy framework and a handbook on returns with child-specific considerations at the EU level, there no common framework at a global level to ensure child rights-compliant and child-sensitive returns and reintegration between countries. The Global Compact for Safe, Orderly and Regular Migration, which was finalised in July 2018 and is due to be adopted by all Member States in Marrakech in December 2018, provides the first comprehensive governance framework on international migration and outlines a set of objectives, commitments and actions on which States should cooperate, including on safe, dignified return, readmission and sustainable reintegration (Objective 21).

- A clear set of principles, standards and indicators - particularly on child-sensitive returns and reintegration - in line with children's rights should guide the coordinated response from the UN to support governments in their implementation of the Global Compact.A more consistent definitional approach is necessary, especially around voluntariness of departure and returns and what this means for children.

(2)

\section{The UN should facilitate the creation and/or} strengthening of national monitoring mechanisms on return.

- This can be done in partnership with relevant stakeholders - including national human rights institutions that provide independent recommendations on ways and means to strengthen accountability - to guarantee the safety, dignity and human rights of all returning migrants, with attention to the specific needs of returnee children.
The UN should coordinate with civil society and other stakeholders to create a fully-functioning capacity-building mechanism for the Global Compact for Migration.

- This should include a mechanism to strengthen the capacity of migration authorities, border officials and service providers to meet the needs of children in child-friendly best interests determination procedures, including return. The global community as a whole can, through implementing the Global Compact on Migration, push for broader responsibility sharing around sustainable and durable solutions and child safeguarding - and, through this, improve the situation of child migrants. 
BIBLIOGRAPHY

Act relating to the strengthening of the status of Human Rights in Norwegian law (1999). https://bit.ly/2A1QpSI

Afghanistan Central Statistics Organization. "Afghanistan Living Conditions Survey 2013-14," n.d. https://bit.ly/2pMW6xT

_ “National Risk and Vulnerability Assessment 2011 - 2012," 2012. https://bit.ly/2yfsgal

Afghanistan Research and Evaluation Unit. "Second-Generation Afghans in Iran: Integration, Identity and Return," April 2008. https://bit.ly/2RG2pQG

Al-Jazeera. "ISIL Claims Attack on Save the Children in Jalalabad,” January 25, 2018. https://bit.ly/2C7i71N

Amnesty International. "Forced Back to Danger - AsylumSeekers Returned from Europe to Afghanistan.” Amnesty International, October 2017. https://bit.ly/2QHAKxn

“Antrags-, Entscheidungs- Und Bestandsstatistik.” Bundesamt fÜr Migration und FlÜchtlinge, 2017.

https://bit.ly/2OeYpZ3

Antwort der Bundesregierung auf die Kleine Anfrage der Abgeordneten Ulla Jelpke, Sevim Da冈delen, Inge Höger, weiterer Abgeordneter und der Fraktion DIE LINKE. Bundestag,April 20, 2017. https://bit.ly/2pMybhS

Asylos. “Afghanistan: Situation of Young Male 'Westernised' returnees to Kabul.” August 2017. https://bit.ly/2Oebdz0

Aviv, Rachel. “The Trauma of Facing Deportation.” The New Yorker,April 3, 2017. https://bit.ly/2xqpYCi

Barbulescu, Roxana, and Jean Grugel."Unaccompanied Minors, Migration Control and Human Rights at the EU's Southern Border:The Role and Limits of Civil Society Activism.” Migration Studies, February 24, 2016.

https://bit.ly/2CBqAvf

Birkbeck University of London. "Race, Mental Health and State Violence,” June 7, 2018. https://bit.ly/2IMTYyL

Bjelica, Jelena. "EU and Afghanistan Get Deal on Migrants: Disagreements, Pressure and Last Minute Politics.” Afghanistan Analysts Network, October 6, 2016.

https://bit.ly/2EU8J06

Bjelica, Jelena, and Ruttig Thomas. "Voluntary and Forced Returns to Afghanistan in 2016/17:Trends, Statistics and Experiences." Afghanistan Analysts Network, May 19, 2017. https://bit.ly/2qHelpN

Brownlees, Laura, and Terry Smith. “Age Assessment:A Technical Note.” UNICEF, n.d. https://uni.cf/2C9tRRIf

Chadwick, Lauren. “Afghan Forces Use Child Soldiers, and the U.S. Still Gives Them Money.” Foreign Policy,August 3, 2016. https://bit.ly/2b2r50B

Child Protection Working Group. "Minimum Standards for Child Protection in Humanitarian Action,” 2012.

https://bit.ly/2zjApLe

"Civil Society Organisations: New EU Commission Plans on Returns and Detention Will Create Harm and Suffering,' March 3, 2017. https://bit.ly/2EaSxM3
Committee on the Protection of the Rights of All Migrant Workers and Members of Their Families, and Committee on the Rights of the Child. "Joint General Comment No. 4 (2017) of the Committee on the Protection of the Rights of All Migrant Workers and Members of Their Families and No. 23 (2017) of the Committee on the Rights of the Child on State Obligations the Human Rights of Children in the Context of International Migration in Countries of Origin, Transit, Destination and Return," November 16, 2017. https://bit.ly/2IO4ZQq

Constable, Pamela. "Civilian Casualties in Afghanistan at Near-Record Level This Year,According to U.N. Report." The Washington Post,April 13, 2018.

https://wapo.st/2ProLDF

— "Returned to a Land of War and Want."

The Washington Post, n.d. https://wapo.st/2A1Fulu

Danish Refugee Council, and Samuel Hall."Urban Poverty Report," 2014. https://bit.ly/2C4joGR

- "Designing Livelihood Programmes for Displaced Populations in Urban Settings in Afghanistan and Pakistan," 2013.

https://bit.ly/2RBuoAZ

DW."When an Asylum Request Is Rejected," November 2, 2017. https://bit.ly/2Prs2mu

- "German Doctors Reject Mandatory Age Tests for Asylum Seekers," January 1, 2018. https://bit.ly/2yvV3qa

ECRE."The Afghan Paradox - Chaos and Violence but Safe for Returns from Europe," February 2, 2018. https://bit.ly/2s3XnEG

- "EU Migration Policy and Returns: Case Study on Afghanistan," November 2017. https://bit.ly/2AhdmSa

European Commission against Racism and Intolerance. "ECRI General Policy Recommendation No. 16 on Safeguarding Irregularly Present Migrants from Discrimination," March 16, 2016. https://bit.ly/2INWxRe

European Migration Network."EMN Ad-Hoc Query on Return of Unaccompanied Minors," 2017. https://bit.ly/2NAJW4C

- "EMN Policy Brief on Migrants' Movements through the Mediterranean," December 1, 2017. https://bit.ly/2EcKcXZ

European Parliament. Directive 2008/115/EC of the European Parliament and of the Council of 16 December 2008 on common standards and procedures in Member States for returning illegally staying third-country nationals (2008) https://bit.ly/2yvu3a0

European Reintegration Network. "European Reintegration Network (ERIN) Specific Action Program - Afghanistan Briefing Note." European Union, n.d. https://bit.ly/2yaJpBF

European Union. "EU Guidelines on the Protection and Promotion of the Rights of the Child." Accessed March 7, 2018. https://bit.ly/2ytFl9u

European Union Agency for Human Rights. "Fundamental Rights Considerations of Apprehending Irregular Migrants," September 10, 2012. https://bit.ly/2CzWHey

Eurostat."Eurostat Database" n.d. https://bit.ly/2C7/zsb

Farmer,Alice. "A Commentary on the Committee on the Rights of the Child's Definition of Non-Refoulement for Children: Broad Protection for Fundamental Rights." Human Rights Watch, December 21, 2011. https://bit.ly/2PrseSK

Forced Migration Review. “Afghanistan's Displaced People: 2014 and Beyond," May 2014. https://bit.ly/2PoeE2v 
Forfangs, Frode. "Is Afghanistan «safe»?" Frode Forfangs blogg, n.d. https://bit.ly/2CzDQ3d

Gladwell, Catherine. "No Longer a Child: From the UK to Afghanistan | Forced Migration Review." Accessed January 23, 2018. https://bit.ly/2Efz3FY.

Global Detention Project. "Country Detention Report Immigration Detention in Norway," February 2018. https://bit.ly/2QDNqoG

Hoffmeyer-Zlotnik, Paula. "Return Policy in Germany in the Context of EU Rules and Standards." Federal Office for Migration and Refugees and European Migration Network, 2017. https://bit.ly/2Ogihze

Human Rights Watch. "Pakistan Coercion, UN Complicity - The Mass Forced Return of Afghan Refugees." Afghanistan: Human Rights Watch, February 13, 2017. https://bit.ly/217JTD7

— “Seeking Refuge - Unaccompanied Children in Sweden” June 9, 2016. https://bit.ly/1UFpObp

Joint Way Forward on migration issues between Afghanistan and the EU, 4 October 2016, the European Union and the Government of Afghanistan. https://bit.ly/2e3cgw9

Jolyon, Leslie."Political and Economic Dynamics of Herat." United States Institute of Peace, 2015. https://bit.ly/2C8j89B

Ktistakis, Yannis. "Protecting Migrants Under the European Convention on Human Rights and the European Social Chapter -A Handbook for Legal Practicioners." February 2013: Council of Europe, n.d. https://bit.ly/2CaP65q

IASC. "IASC Framework on Durable Solutions for Internally Displaced Persons.” Inter-Agency Standing Committee, April 2010. https://bit.ly/2RFanJH

IFRC. "Protection and Assistance for Children on the Move." IFRC, 2017. https://bit.ly/2INcZB5

International Labour Organisation. "Statistics, Afghanistan," n.d. https://bit.ly/2IN3xhk

International Detention Coalition. "Captured Childhood: Introducing a New Model to Ensure the Rights and Liberty of Refugee,Asylum Seeker and Irregular Migrant Children Affected by Immigration Detention," 2012. http://bit.ly/2RFynfA

IOM. “Overview of Voluntary Returns in 2016." Afghanistan, 2017. http://bit.ly/2RHVaaz

— "Assisted Voluntary Return and Reintegration," n.d. http://bit.ly/2NzqDsr

- "Towards an integrated approach to reintegration in the context of return." 2017. http://bit.ly/2IPLUOf

— "Unaccompanied Children on the Move." IOM, 2010. http://bit.ly/2EfRNoW

— “Migration Governance Framework" http://bit.ly/2EenlLT

— “Glossary on Migration, 2nd Edition," 2011.

http://bit.ly/2/Nfvas

- "Towards an Integrated Approach to Reintegration in the Context of Return," 2016. http://bit.ly/2IPLUOf

— “Migration Governance Framework," n.d. http://bit.ly/2EenlLT

- "Supporting Safe, Orderly and Dignified Migration through Assisted Voluntary Return and Reintegration," n.d. http://bit.ly/2EmpLb4
Kellett, Mary. "Children as active researchers: a new research paradigm for the 21st century?" 2005, ESRC National Centre for Research Methods.

Lemberg-Pedersen, Martin. "The Rise and Fall of the ERPUM

Pilot - Tracing the European Policy Drive to Deport

Unaccompanied Minors." Refugee Studies Centre, Oxford

Department of International Development, University of

Oxford, March 2015. http://bit.ly/2A4J7xp

Lind, Dara. "The Trump Administration's Separation of Families at the Border, Explained.” Vox, June 15, 2018.

http://bit.ly/2A4peGB

The Local. "Norway to End Accommodation of Asylum Families at Detention Centre,” December 29, 2017. http://bit.ly/2ywpFI5

- “Impact of Sweden's Asylum Age Assessment Tests Revealed,' December 4, 2017. http://bit.ly/2EcX9B3

Majidi, Nassim. "From Forced Migration to Forced Returns in Afghanistan: Policy and Program Implications," November 2017. http://bit.ly/2pKNGad

- "Young Afghans Returning From Europe Face Isolation and Fear Back Home.” Refugees Deeply, November 16, 2016. http://bit.ly/2OjuL5b

Malmqvist, Erik, Elisabeth Furberg, and Lars Sandman. "Ethical Aspects of Medical Age Assessment in the Asylum Process:A

Swedish Perspective." International Journal of Legal Medicine, May 2018. http://bit.ly/2QKEWMW

“Migration Data Portal," consulted on February 2018.

http://bit.ly/2yF8ioz

Mashal, Mujib, and Fahib Abed."Grounded and Gutted, Main Afghan Airline Struggles After Taliban Attack." The New York Times, January 26, 2018. https://nyti.ms/2A3Vb1Y

McClenaghan, Maeve. "Refugee Crisis:Afghanistan Ruled Safe Enough to Deport Asylum-Seekers from UK.” March 3, 2016. https://ind.pn/2yedsbH

Muižnieks, Nils, Commissioner for Human Rights. "2nd Quarterly Activity Report 2015." Council of Europe, 2015. https://rm.coe.int/ref/CommDH(2015)19.

Norsk Organisasjon for Asylsøkere. "The Asylum Process in Norway,” n.d. http://bit.ly/2CCUBum

Norsk Organisasjon for Asylsøkere, and Save the Children.

“Over eller under 18?," 2016. http://bit.ly/2QKt4ug

— “《Jeg har ikke gjort noe galt»," 2017. http://bit.ly/2OPDjzZ

Norway Today. “Asylum Seekers Win Appeal in Trial about Age Testing," December 1, 2017. http://bit.ly/2NyZk1m

Norwegian Directorate of Immigration, "Asylum Decisions for Unaccompanied Minors by Citizenship and Outcome (2017)." 2017. http://bit.ly/2EbcQcg

- "Information about Returns to Afghanistan," February 19, 2016. http://bit.ly/2yuUbSE

Norwegian Ministries. "Immigration and Integration 20162017,” 2017. http://bit.ly/2CC83Ps

Norwegian Refugee Council." "Freeze Afghan Deportations: The War Is Back and Worsening." Accessed February 25, 2018. http://bit.ly/2PrFSW7

- "Afghanistan Attack Targets Kabul Classroom with 600 Children Inside," March 19, 2018. http://bit.ly/2PrGWt5 
Norwegian Refugee Council, and Samuel Hall,"A postdeportation protection framework: deportations from Iran to Afghanistan", unpublished.

- "Access to Tazkera and Other Civil Documentation in Afghanistan," November 8, 2016. http://bit.ly/2EcXRhH

- "A Post-Deportation Protection Framework: Deportations from Iran to Afghanistan," unpublished.

OHCHR. "Children Must Be Top of Global Migration Agenda, UN Experts Say,” November 17, 2017. http://bit.ly/2yuUZqt

Oxfam. "Returning to Fragility: Exploring the Link between Conflict and Returnees in Afghanistan." Oxfam, January 31, 2018. http://bit.ly/2OPDBH5

Parliamentary Assembly of the Council of Europe. "States Must Ban the Detention of Migrant Children," September 9, 2014. http://bit.ly/2REyuYW

— "Unaccompanied Children in Europe: Issues of Arrival, Stay And," March 21, 2011. http://bit.ly/2RHO4TK

Parusel, Bernd. "Unaccompanied Minors in Germany Reception, Return and Integration." Germany Federal Office for Migration and Refugees, 2008. http://bit.ly/2NAdHmc

— “Sweden's Asylum Procedures." Bertelsmann Stiftung, 2016. http://bit.ly/2OjiEJI

Pétin, Joanna. "Exploring the Role of Vulnerability in Immigration Detention." Refugee Survey Quarterly Volume 35, no. Issue 1 (February 2, 2016). http://bit.ly/2C6zyzv

Platform for International Cooperation on Undocumented Migrants. "A Child Is a Child - How the European Union Can Ensure the Rights of Undocumented Migrant Children," March 3, 2014. http://bit.ly/2CBjOkd

PM and others (Kabul, Hizb-i-Islami) (Asylum and Immigration Tribunal November 12, 2007). http://bit.ly/2yeP4GL

Radio Free Europe. "Afghan Police: Children Kidnapped To Be Suicide Bombers For Taliban,” July 10, 2017.

http://bit.ly/2NBVPai

REACH. "Education and Child Protection - Joint Needs Assessment," November 2017. http://bit.ly/2NB5fmv

Refugee Council of Australia. "Addressing The Pain of Separation for Refugee Families,” November 2016. http://bit.ly/2pP5nFH

Refugee Support Network (RSN), “After Return: Documenting experiences of Young People removed to Afghanistan.” April 2016. http://bit.ly/2OTGAhN

Regulations of 15 October 2009 on the Entry of Foreign Nationals into the Kingdom of Norway and they Stay in the Real (Immigration Regulations) (2009). http://bit.ly/2yuX0Ty

Reuters. "Security Situation in Afghanistan Likely to Get Worse: U.S. Intel Chief," May 12, 2017. https://reut.rs/2NCSkAN

Ruttig,Thomas. "More Violent, More Widespread:Trends in Afghan Security in 2017." Afghanistan Analysts Network, January 29, 2018. http://bit.ly/2OTYZuT

Samuel Hall."Urban Displaced Youth in Kabul - Part One: Mental Health Matters," 2016. http://bit.ly/2RJGqZ9

— "Out-of-school Children Initiative", forthcoming, for UNICEF.

- "Hanging by a thread: understanding and addressing child labour in the carpet weaving sector in Afghanistan", 2016. UNICEF Afghanistan.
Samuel Hall, and IOM. "Setting Standards for an Integrated Approach to Reintegration," 2017, funded by DFID. http://bit.ly/2CCdJsr

Samuel Hall, and NRC/IDMC. "Escaping War:Where to Next? A research Study on the Challenges of IDP Protection in Afghanistan", 2018, commissioned by NRC/IDMC and funded by the European Union and the Norwegian Ministry of Foreign Affairs.

- 'Going 'Home' to Displacement, Afghanistan's ReturneeIDPs”, 2017. http://bit.ly/2CBgESv

Save the Children. "Hear It From the Children - On the Move and Arriving in Norway." Norway: Save the Children, 2016. http://bit.ly/2OIJYCL

- "Knowledge,Attitudes and Practices on Violence and Harmful Practices Against Children in Afghanistan - A Baseline Study," 2017. http://bit.ly/2ysKX9m

Save the Children, and UNHCR. "Separated Children in Europe Programme - Statement of Good Practice," 2004. http://www. unhcr.org/4d9474399.pdf.

Save the Children, and UNICEF."Rapid Assessment of Education Needs of Returnee Children in Afghanistan,” November 2016. http://bit.ly/2yuuK31

Schuster, Liza, and Majidi, Nassim. "Deportation, Stigma and Remigration", in The Journal of Ethnic and Migration Studies, volume 41, issue 4, 2015.

Shea,Anna. "Europe Is Betraying Afghanistan By Sending Its Refugees Home." October 5, 2017. https://ti.me/2OOYjXQ

Staver, Anne, and Hilde Lidén. "Unaccompanied Minors in Norway: Policies, Practices and Data in 2014." Institutt for samfunnsforskning, 2014. http://bit.ly/2ydCSG9

Sweden's Alien's Act (2005). http://bit.ly/2A3YuGq

Swedish Migration Agency. "If You Will Turn 18 Soon" n.d. http://bit.ly/2NAwqha

- "Assessment of your age as a part of your identity" n.d. http://bit.ly/2EgXOI5

- "Return voluntarily to your country of origin after your asylum application is refused" n.d. http://bit.ly/2RCXxvo

The Guardian. "Afghanistan Tackles Hidden Mental Health Epidemic,” September 2, 2015. http://bit.ly/2PtPXlg

The Independent. "Refugee Crisis:Thousands of Child Asylum Seekers Deported Back to War Zones, Home Office Admits," February 9, 2016. https://ind.pn/2ysL5pm

The World Bank. "Kabul Urban Policy Notes Series n.3," n.d. http://bit.ly/2C7500y

TOLO News. "Denmark, Norway Eye Kabul Center for Minors Denied Asylum,” June 21, 2018. http://bit.ly/2NzQDUv

— "Eight Herat Districts Facing Security Threats: Residents,"

July 31, 2017. http://bit.ly/2Onjm40

UN. “Convention on the Rights of the Child," 1989. http://bit.ly/2NzQFM7

- "General Comment No. 6." Committee on the Rights of the Child, 2005. http://bit.ly/2PqGbAn

- "General Comment No. 14 (2013) on the Right of the Child to Have His or Her Best Interests Taken as a primary Consideration (Art. 3, Para. 1)," Committee on the Rights of the Children, May 29, 2013. http://bit.ly/2QIrxEP 
— "Joint General Comment No. 4 (2017) of the Committee on the Protection of the Rights of All Migrant Workers and Members of Their Families and No. 23 (2017) of the Committee on the Rights of the Child on State Obligations Regarding the Human Rights of Children in the Context of International Migration in Countries of Origin, Transit, Destination and Return." Committee on the Protection of the Rights of All Migrant Workers and Members of Their Families and Committee on the Rights of the Child, November 16, 2017. http://bit.ly/2NAXxJk

- "Principles and Guidelines, Supported by Practical Guidance, on the Human Rights Protection of Migrants in Vulnerable Situations," n.d. http://bit.ly/2/QfqTo

UN Secretary General. "Special Report on the Strategic Review of the United Nations Assistance Mission in Afghanistan," August 10, 2017. http://bit.ly/2NBYvon

UNAMA. "Midyear Update on the Protection of Civilians in Armed Conflict: 1 January to 30 June 2018," July 15, 2018. http://bit.ly/2OREtLv

- "Special Report on the Strategic Review of the United Nations Mission in Afghanistan.” Afghanistan: UN, August 2017. http://undocs.org/S/2017/696.

UNAMA, and OHCHR. "Afghanistan - Protection of Civilians in Armed Conflicts - Mid-Year Report 2017.” Afghanistan: UNAMA, OHCHR, n.d. http://bit.ly/2EdWQpE

UNHCR. "Advisory Opinion on the Extraterritorial Application of Non-Refoulement Obligations under the 1951 Convention Relating to the Status of Refugees and Its 1967 Protocol." UNHCR, January 2007. http://www.unhcr.org/4d9486929.pdf.

— “Global Trends - Forced Displacement in 2015," 2015. http://bit.ly/2QKx7GY

— "UNHCR's Position Regarding the Detention of Refugee and Migrant Children in the Migration Context," January 2017. http://bit.ly/2NAHtav

- "Options Paper 1: Options for Governments on Care Arrangements and Alternatives to Detention for Children and Families," 2015. http://www.refworld.org/docid/5523e8d94.html

- "Guidelines on International Protection: Child Asylum Claims under Articles 1(A)2 and 1(F) of the 1951 Convention and/or 1967 Protocol Relating to the Status of Refugees," December 22, 2009. http://www.unhcr.org/50ae46309.pdf.

- "UNHCR Guidelines on Determining the Best Interests of the Child," May 2008. http://bit.ly/2OWyXag

- "UNHCR Observations on the Use of Age Assessments in the Identification of Separated or Unaccompanied Children Seeking Asylum," June 1, 2015.

http://www.refworld.org/pdfid/55759d2d4.pdf.

- "The Internal Flight Alternative in Norway:The Law and Practice with Respect to Afghan Families and Unaccompanied Asylum-Seeking Children - A Mini-Assessment Commissioned by UNHCR." Afghanistan: UNHCR, June 2017. http://bit.ly/2Ptfuey.

- "This Is Who We Are - A Study of the Profile, Experiences and Reasons for Flight of Unaccompanied or Separated Children from Afghanistan Seeking Asylum in Sweden in 2015." Afghanistan, Sweden: UNHCR, October 2016.

http://bit.ly/2OQJLqE

— "Tough Choices for Afghan Refugees Returning Home after Years in Exile." ReliefWeb, n.d. http://bit.ly/2NC6f9V
- "Deportation and the Liberal State:The Forcible Return of Asylum Seekers and Unlawful Migrants in Canada, Germany and the United Kingdom," February 2003. http://bit.ly/2NB7HJK

- "Handbook on Procedures and Criteria for Determining Refugee Status under the 1951 Convention and the 1967 Protocol Relating to the Status of Refugees,' January 1992. http://www.unhcr.org/4d93528a9.pdf

- "Handbook for Repatriation and Reintegration Activities," May 2004. http://bit.ly/2PsLq2C

— "Handbook - Voluntary Repatriation: International Protection," 1996. http://www.unhcr.org/uk/3bfe68d32.pdf

UNICEF."Silent Harm:A Report Assessing the Situation of repatriated Children's Psycho-Social Health," March 2012. https://uni.cf/2EflLrN

— "What Is Child Protection?" May 2006. https://uni.cf/2EbAjKo

- "Children's Rights in Return Policy and Practice in Europe," 2015. http://bit.ly/2A3VIGt

- "Convention on the Rights of the Child - Frequently Asked Questions," n.d. https://uni.cf/2CCoOVz

— "Fact Sheet: A Summary of the Rights under the Convention on the Rights of the Child," n.d. https://uni.cf/2QLTprV

UNICEF, and Samuel Hall. "Social Protection System:An Afghan Case Study - Analysing the Potential of a Child-Focused Social Protection Cash Transfer Programme in Balkh,” 2014.

http://bit.ly/2OWzUzm

UNICEF, and UNHCR. "Safe \& Sound - What States Can Do to Ensure Respect for the Best Interests of Unaccompanied and Separated Children in Europe," October 2014.

http://bit.ly/2RGvpHK

University of Oslo Faculty of Law. “'Kids in Limbo?' - An Analysis of Temporary Residence Permits to Unaccompanied Asylum,” May 15, 2013. http://bit.ly/2C7306O

UNOCHA. "Afghanistan: 2017 Humanitarian Response Plan - Mid-Year Review (January - June 2017).” Afghanistan: UNOCHA, 2017. http://bit.ly/2CBrAj1

— "2018 Afghanistan Humanitarian Needs Overview,"

December 1, 2017. http://bit.ly/2NAIQqM

US Department of State. "Trafficking in Person Report," June 2018. http://bit.ly/2PrlleJ

VG. "UDI: Bare to Av Afghanistans 34 Provinser Er Utrygge," April 4, 2017. http://bit.ly/2A45qTY

Walter-Franke, Marie. "Asylum Detention in Europe: State of Play and Ways Forward." Jacques Delors Institut, May 18, 2017. http://bit.ly/2OR5MFv

Zevulun, Daniëlle. "Repatriation and the Best Interests of the Child." University of Groningen, 2017. http://bit.ly/2NBbLKa

Zevelun, Daniëlle. "The Best Interests of the Child from Different Cultural Perspectives." Accessed March 7, 2018. http://bit.ly/2QJNUcX 

Save the Children

(C) Save The Children Sweden, 2018 